\title{
Cultivation of Macroscopic Marine Algae and Fresh Water Aquatic Weeds
}

John H. Ryther

Woods Hole Oceanographic Institution

Woods Hole, Massachusetts 02543

February 1982

Prepared Under Task No. 3337.01

WPA No. 274-81

Solar Energy Research Institute

A Division of Midwest Research Institute

1617 Cole Boulevard

Golden, Colorado 80401

Prepared for the

U.S. Department of Energy

Contract No. EG-77-C-01-4042 
Printed in the United States of America Available from:

National Technical Information Service

U.S. Department of Commerce

5285 Port Royal Road

Springfield, VA 22161

Price:

Microfiche $\$ 3.00$

Printed Copy $\$ 6.50$

\section{NOTICE}

This report was prepared as an account of work sponsored by the United States Government. Neither the United States nor the United States Department of Energy, nor any of their employees, nor any of their contractors, subcontractors, or their employees, makes any warranty, express or implied, or assumes any legal liability or responsibility for the accuracy, completeness or usefulness of any information, apparatus, product or process disclosed, or represents that its use would not infringe privately owned rights. 
FOREWORD

High yields exhibited by macroalgae and floating aquatic plants make these types of plants attractive as potential sources of biomass for conversion to fuels and chemicals. Research to quantify the value of various species has been funded by Energy Research Development Administration (ERDA) and the Department of Energy (DOE) since the mid-1970s. This report describes work performed by the Woods Hole Oceanographic Institution for the Solar Energy Research Institute (SERI) under Subcontract XR-9-8133-1, using funds provided by the Biomass Energy

Technology Division of the DOE. Field management responsibility for this ongoing subcontract, formerly DOE Contract No. EY-76-S-02-2948, was transferred to SERI from ERDA in May 1979.
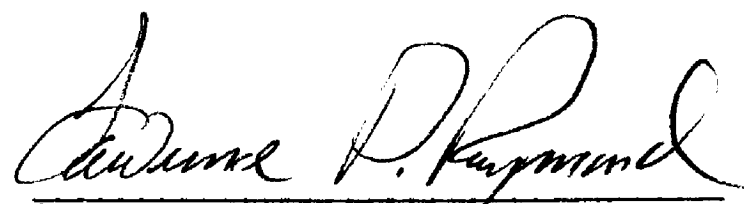

Lawrence P. Raymond, Manager

Biomass Program Office 
The "ORCA" clone of the red seaweed Gracilaria tikvahiae has been in culture continuously for over two years. Yield for the past year has averaged $12 \mathrm{~g}$ ash-free dry $w t / \mathrm{m}^{2}$. day $(17.5 \mathrm{t} / \mathrm{a} \cdot \mathrm{yr})$ in suspended 2600-1 aluminum tank cultures with four exchanges of enriched seawater per day and continuous aeration, the same yields as obtained by similar methods during the previous year. With improved culture medium, comparable yields could be obtained at one exchange of seawater per day and with aeration only during daylight.

Ylelds from non-intensive pond-bottom culture, similar to commercial Gractlaria culture methods in Taiwan, averaged $3 \mathrm{~g}$ afdw/m $\mathrm{m}^{2}$. day in preliminary experiments. Cultures provided with a continuous flow of enriched seawater became heavily epiphytized and died, but exposing the seaweed to the same amount of nutrients for 48 hrs (with flow stopped) every two weeks prevented epiphyte growth and maintained healthy plants. Deeper $(0.8 \mathrm{~m})$ water and gentle aeration to prevent stratification were necessary in summer, while shallow $(0.04 \mathrm{~m})$, nonaerated cultures grew well in winter. Soil bottom was found to be non-essential. Rope and spray cultures were not successful.

Two $10,000 \mathrm{~m}^{2}$ (ca. $1 / 4$ acre) demonstration-ponds were constructed and partially stocked with Gracilaraia and water hyacinths respectively and will be used to provide data for future economic and energy cost:benefit analysis. Yields of water hyacinths from March 1978 to March 1979 averaged $25.7 \mathrm{~g} \mathrm{afdw} / \mathrm{m}^{2}$.day ( $37 \mathrm{t} / \mathrm{a} \cdot \mathrm{yr}$ ), one-third higher than for the previous 
year, the difference probably reflecting normal year-to- year varlability. Weevils of the genus Neochetina, introduced to Florida to control water hyacinths, infested the cultures during 1979 and set back growth until successful aerial application of systemic organophosphate insecticide was initiated. Season, nutrient availability (form and quantity) and stand density were found to affect the relative proportions of structural and non-structural tissue in water hyacinths and thereby significantly affect digestibility of and methane production by the plants.

Pennywort ( Hydrocotyle) grew poorly in winter and its annual yield averaged only one-third that of water hyacinth. Water lettuce (Pistia) appears more comparable to hyacinths in preliminary studies and its yields will be monitored throughout a complete year.

Water-loss from evapotranspiration of pennywort, water hyacinths and duckweed over a nine-mc nth period was found to be $2.0,1.7$ and 0.9 times respectively the loss of water from evaporation alone. Evapotranspiration losses were correlated with various environmental and biological factors. Extrapolated annual FT loss from water hyacinths was equivalent to 3 million gallons/acre, $41 \%$ of which was in excess of evaporation from a bare water surface.

Stable, continuous anaerobic digestion of both water hyacinths and Gracilaria has now been maintained for over one year with an average gas production from both species of $0.4 \mathrm{l} / \mathrm{g}$ volatile solids at $60 \%$ methane. 
Solid and 1 iquid residues from anaerobic digestion of water hyacinths were found to be a superior source of nutrients to chemical defined enrichment medium for new growth of the plants. Nutrients were recycled from plants to digester residue and back into the plants with an overall efficiency of $64.5 \%$. Solid residues from the anaerobic digestion of Gracilaria could not be similarly recycled, but the 1 iquid residue, containing $65 \%$ of the nitrogen, was recycled from seaweed to digester residue and back to the seaweeds at an overa11 efficiency of $48 \%$. 
Tab1e of Contents

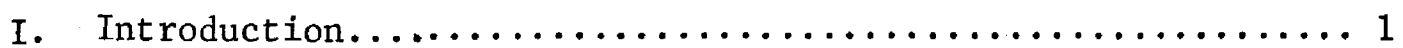

II. Seaweed culture - M. Dennis Hanisak and Richard W. Stenberg..17

III. Freshwater macrophyte culture - Thomas A. DeBusk..........27

IV. Effects of seasonality, nitrogen form and availability and plant stand density on the chemical composition and nutritive value of water hyacinth (Eichhornia crassipes) -

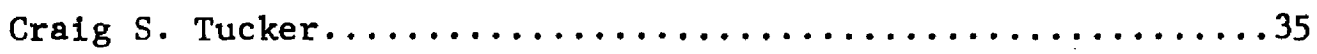

V. Growth and yield of aquatic plants - John H. Ryther.......55

VI. Evapotranspiration of some emergent freshwater plants -

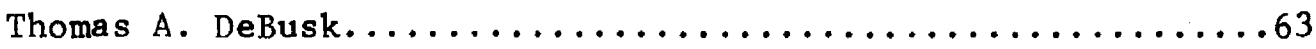

VII. Recycling digester residues as a source of nutrients for the growth of water hyacinths (Eichhornia crassipes) M. Dennis Hanisak and L. D. Williams..................

VIII. Recycling digester residues as a source of nutrients for the growth of Gracilaria tikvahiae - M. Dennis Hanisak and

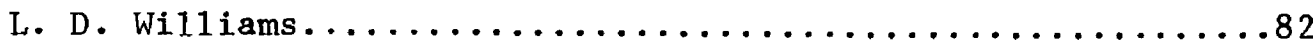




\section{Introduction}

A. Seaweed culture:

The "ORCA" clone of the red seaweed Gractlaria tikvakiae, isolated in December 1977, has now been grown continuously in 2600-1 aluminum tank culture for two years. Yields of the seaweed over the past twelve months, in cultures receiving four exchanges of water per day enriched with 50-100 $\mu$ moles/1 $\mathrm{NO}_{3}-\mathrm{N}, 5-10 \mu$ moles/1 $\mathrm{PO}_{4}-\mathrm{P}$ and trace metals (concentrations of enrichment depending upon the nutrient content of the seawater) and in vigorous aeration maintaining the plants in suspension, have averaged $12 \mathrm{~g}$ ash-free dry weight $/ \mathrm{m}^{2}$.day, equivalent to approximately $44 \mathrm{t}$ afdw/hectare.year (17.5 t/acre.year). These yields are almost exactly the same as those obtained using similar methods over the previous year.

During the past year a new nutrient enrichment procedure was initiated in which the commercial inorganic trace metal mixture, used alone up to that time, was supplemented with a chelated fron source (Fe-EDTA). Fo1lowing that change in enrichment procedure, new experiments on the effect of reducing the flow of water through the cultures proved highly successful, growth at one volume exchange/day being equal to that obtained with four exchanges/day. It was concluded that, with the earlier inorganic trace element enrichment procedure, one or more essential elements precipitated in the seawater or were otherwise made unavaliable to the plants, and that the increased growth with increasing rates of water exchange had resulted from an 
enhanced supply of the limiting trace element(s) in the seawater. For reasons not understood, that effect was not apparent when it was looked for in the smaller (50 1), screening tanks, perhaps because it was obscured by other growth-1imiting factors associated with slow exchange rates in the smaller cultures (i.e., large fluctuations in temperature and $\mathrm{pH}, \mathrm{CO}_{2}$ limitation, or perhaps other chemical and/or physical stresses).

The achievement of high yields of Gracilaria at low water exchange rates is a major accomplishment, because the cost, economically and in terms of energy, of continuously pumping large volumes of water would represent a major constraint to an intensive seaweed culture operation, no matter how large the yield. New experiments will now be undertaken in which the rate of exchange of water will be reduced further, using both continuous and pulsed water supply, until a minimum flow rate consistent with high yields is established.

A discovery of similar significance to the economic and energy cost of intensive seaweed culture was the demonstration that yield is not affected by restriction of aeration to the 12 daylight hours (i.e., In contrast to continuous aeration). This finding is still tentative and will require further confirmation, but if the results of the preliminary findings are repeated, additional experiments in this area will also be undertaken, reducing both the quantity and period of aeration until the minimum requirement of that costly procedure is also determined. 
Gracilaria has also been grown, using a variety of non-intensive culture methods, in a series of PVC-1ined earthen ponds rangIng in bottom areas from 10 to $20 \mathrm{~m}^{2}$, in depth, from 0.4 to $0.8 \mathrm{~m}$, and in volume from 5,400 to 24,000 liters.

In one series of such experiments, the seaweeds were floated on the pond surface in plastic-mesh trays, the plants just submerged below the water surface, and enriched seawater was continuously pumped from the pond bottom and sprayed, through conventional shower heads, onto the trays from above. The Gracilaria in these experiments became heavily epiphytized, primarily with the filamentous green alga Enteromorpha sp., and eventually died.

In another series of non-intensive culture experiments, pieces of Gracilaria $10-20 \mathrm{~cm}$ in length were inserted into the weave of polypropylene rope at intervals of rough1y $10 \mathrm{~cm}$ and the ropes were suspended in the ponds at various distances off the bottom. These plants also became heavily infested with epiphytes and failed to grow. Several attempts were made to grow the seaweeds passively on the bottoms of the ponds in a manner similar to that employed in the commercial Gracilaria culture industry of Taiwan. Mixed results have been obtained from the bottom culture experiments, which are continuing, but the tentative conclusions that have been reached to date are:

1) Using two exchanges of water per day and continuous enrichment

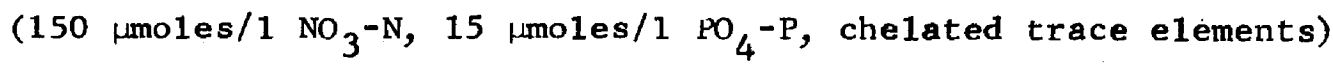
gave poor results, the seaweeds becoming heavily infested with epiphytes and eventually dying. 
2) Using the same flow rate but pulsing the nutrients, stopping the flow for 48 hours every two weeks and adding an amount of nutrients comparable to that which would be provided in (1) above over the two-week period, prevented eplphyte development and resulted in good growth of the Gracilaria.

3) The use of shallow $(0.4 \mathrm{~m})$ ponds resulted in good growth in winter and poor growth in summer. Deep $(0.8 \mathrm{~m})$ ponds produced yields that were intermediate throughout the year. Thus, use of deep ponds in summer and sha1low ponds in winter is indicated.

4) Gentle aeration, insufficient to move the seaweed but enough to circulate the water and break down thermal stratification, appears necessary in summer but is not required in winter.

5) The use of a sand-soil substrate on the bottoms of the PVClined ponds did not enhance growth.

Mean yields of Gracilaria in the non-intensive pond-bottom cultures that have proved successful to date, since these experiments were initiated in May, 1979, has been about $3 \mathrm{~g}$ afdw/ $/ \mathrm{m}^{2}$. day $(10 \mathrm{t} /$ ha.year or 4 t/acre.year), about one-quarter of the yields obtained by the intensive culture methods. However, this research is still in a relatively early stage of development and is continuing, so some improvement in yields may be anticipated as more experience is obtained with these methods.

A major purpose of the non-intensive pond culture experiments is to develop the most promising method for growing Gracilaria in the 
one-quarter acre $\left(10,000 \mathrm{ft}^{2}\right)$ demonstration unit that was completed in the late sumer of 1979 . Initially it was planned to grow a sufficient quantity of the "ORCA" clone to stock the large pond, and the yields of four 2600-1iter aluminum tank cultures and one 25,000 liter aluminum tank culture are presently being used for that purpose. However, to save time over that process, which could take over a year to stock the large pond at the desired density, approximately one ton of Gracilaria was collected from the Indian River in October and used as an initial seed culture, which will continue to be supplemented from the smaller experimental cultures of "ORCA" clone. Thus, it is hoped that sufficient stock will be avallable to initiate seaweed culture experiments in the quarteracre pond by ear1y 1980 .

B. Freshwater macrophyte culture:

In contrast to the seaweed research, whe re several important problems have remained to be resolved, relatively little effort was devoted to new research with freshwater plants during the present contract year. Water hyacinth remains the most promising species with respect to yield and relative freedom from major problems in its cultivation, though some new problems have emerged that will be discussed below.

Initial use of an inorganic trace element enrichment, discussed above in connection with the seaweed culture, was first found to be inadequate for the rapidly-growing water hyacinths, leading to obvious 
chlorosis of the foliage and eventually a cessation of growth. This could be corrected by spraying the foliage directly with the inorganic enrichment medium, but that practice was subsequently replaced by supplementing the medium, with chelated iron, which practice was later adapted for the seaweed culture.

Water hyacinths grown in PVC-1 ined ponds receiving a continuous flow of enriched well water (see previous report for details) exhibited a mean annual yield for the period March, 1978-March, 1979 of $25.7 \mathrm{~g}$ afdw/m $/ \mathrm{m}^{2}$.day, equivalent to some $94 \mathrm{t}$ afdw/ha.year (37 t/a.yr). That is about $1 / 3$ higher than the yield reported for the previous 11 -month period (see previous report), but probably reflects the normal year-to-year varlability in yield that may be expected, particularly for a species living near the limit of its range. In that connection, the higher yield during 1978-79 may have been due partly to the mild winter of that year, during which the plants were not once killed or visibly set back by frost.

A new problem in water hyacinth culture became obvious in May, 1979 with the infestation of the plants by weevils of the genus Neochetina, either or both of the species $\underline{N}$. eichhorniae or $\underline{N}$. bruchi that have been introduced to Florida from South American specifically for the purpose of water hyacinth control. Although apparently not lethal to the plants in themselves, the insects appear to stress them to the extent that other control methods may be effectively used. 
The weevil infestation of the Harbor Branch Foundation population of water hyacinths visibly affected the plants and quantitatively reduced their yield until the insects were brought under control by aerial spraying of the foliage with an organophosphate systemic insecticide (Cygon 2E) ${ }^{*}$. Spraying must now be employed routinely to contro1 the weevil infestation, a practice that could significantly affect the economics of large-scale water hyacinth cultivation.

A new series of experiments has been initiated during the present contract year to investigate the effects of season, nitrogen form and avallability and plant stand density on the chemical composition of water hyacinths. Such variability in composition may have a significant effect upon the value of the plants as a feed or feedsupplement (i.e., through their nutritive value) or as a biomass source for conversion to fuel (i.e., through their energy content and digestability by anaerobic fermentation).

As growth of the plants decreases in winter, due to both reduced temperature and solar radiation, total nitrogen and ash content of the plants increase while lignocellulose and nonstructural carbohydrate levels decrease, while the reverse trend develops as the more active growing season begins in May and continues through the summer. Analyses of inorganic nitrogen levels in the plant tissues indicate that the plants are able to assimilate and store the nutrient in winter, when they are unable to grow or can grow only slowly and cannot convert the nitrogen to plant protein. In summer, when the

*American Cyanamid Co., Princeton, N.J. 
plants can grow but environmental sources of nitrogen may be limiting, the hyacinths are then able to utilize their winter reserves of inorganic nutrients. In this respect, a striking similarity occurs in the strategy of these plants and of temperate species of seaweeds.

Both nitrate- and ammonium-nitrogen are assimilated equal1y wel1 by water hyacinths, though amonia is more readily incorporated into protein, as is true with most plant species. Nitrogen availability has a pronounced effect upon chemical composition of the plants, high availability resulting in correspondingly high levels of protein and ash and low availability resulting in plants with high levels of structural carbohydrates (which reduces their nutritive value and digestability). "High quality" plants, grown at the aquaculture facility with a non-limiting supply of $n$ itrogen produced nearly three times as much biogas per unit weight as did nutrient11mited plants from a natural stand. Thus plants collected from the wild, where nutrients may be growth limiting, or those grown artificlally under similar conditions, may give misleading information concerning the potential value of the species.

Fina11y, water hyacinths in very dense stands are able to grow only vertically with greatly elongated stems relative to those in sparsely populated stands. Vertical elongation requires a substantial increase in structural carbohydates such as lignocellulose and the relative proportion of that substance increases 
correspondingly in dense stands of the species, to the detriment of its nutritive value and digestability to methane. Dense stands of water hyacinths are thus not only undesirable from the point of view of their organic yields (see Chapter 4) but also their composition and value.

An experiment, initiated in 1978, was completed in 1979 in which water hyacinth yields at the Harbor Branch Foundation aquaculture facility, where the plants were grown in continuous-flowing, enriched we11 water, were compared with yields from a eutrophic natural environment. Growth of plants in the two locations was roughly the same during the late winter and early spring when light and/or temperature were presumably the limiting factors, but at other times the yield of the cultured plants increased by several fold while that of the natural stand decreased to levels one-third or less of the cultured plants. This annual study further substantiated the hypothesis, presented in the last report, that biomass yields at the Harbor Branch Foundation facility equalled or, at least, closely approached the maximum potential for the species for the climate and latitude of central florida. Some additional studies were carried out during 1978-79 on other species of freshwater macrophytes, though the effort made in that area was relative1y minor. The pennywort, Hydrocotyle umbellata, which appeared to show some promise a year ago, particularly because it had been found elsewhere to grow at lower temperatures than does water hyacinth, proved to do rather poorly at Harbor Branch Foundation 
during the winter months, with periods of no growth alternating with periods of modest yields. Mean yield of pennywort over a 10-month period was $7.9 \mathrm{~g} \mathrm{afdw} / \mathrm{m}^{2}$.day, only about one-third that of water hyacinths.

Water lettuce, Pistia stratiotes, has been grown for a short period of time during the fall of 1979, during which it averaged $14.4 \mathrm{~g}$ afdw $/ \mathrm{m}^{2}$. day at its optimal density of $160 \mathrm{~g}$ afdw $/ \mathrm{m}^{2}$. Pistia is reportedly even more of a tropical species than water hyacinths and its yields have, in fact, declined from early octoder to late November, but its growth will continue to be monitored chrough the winter of 1979-80 and, if it survives, through 1980, because it appears to be a highly nutritious plant that may have certain advantages over water hyacinth.

Finally, Improved yields of duckweed over those reported in the last report have been described in the literature by means of frequent harvestIng of the new growth so as to maintain a low density and prevent the deleterious effects of overcrowding. These experiments were repeated at Harbor Branch Foundation, comparing yields of cultures from which incremental growth was partially removed each day with that from cultures unharvested over periods of 5-10 days. No yield enhancement was found to result from the frequent harvesting regime.

A second PVC-lined, concrete-wall, one-quarter-acre $\left(10,000 \mathrm{ft}^{2}\right)$ pond, contiguous with that to be used for Gracilaria culture, was also completed in the late summer of 1979 and will be used 
as a demonstration unit to assess the economic and energy cost:benefit ratio of a water hyacinth-based energy farm. The pond was stocked with approximately 3 tons (wet wt) of water hyacinths collected from a wild population during September-October, 1979, and the plants had grown to the extent that they covered approximately half the pond surface at the time this report was prepared.

\section{Evapotranspiration:}

The loss of water from evapo-transpiration of duckweed, water hyacinth and pennywort was measured over a period of nine months from January 17 through September 26, 1979 and compared with water loss from evaporation from a open water surface.

In contrast to the literature, in which most values of the ratio of evapotranspiration to evaporation $(\mathrm{ET} / \mathrm{E})$ are of the order of 3-4 with some as high as $6, \mathrm{ET} / \mathrm{E}$ for water hyacinths for the above period was only 1.7 and that for pennywort, 2.0. Duckweed, with a $\mathrm{ET} / \mathrm{E}$ of 0.9 serves as a water conservation device.

Extrapolation of the observed water loss from a solid cover of water hyacinths to a complete year gives an equivalent water loss of three million gallons per acre of plant surface, of which 1.2 million $(41 \%)$ is in excess of the amount that would be lost from a bare water surface alone.

Linear regression of water loss from the three aquatic plant species with various meteorlogical and blological parameters showed a high correlation with incident solar radiation, temperature and 
plant yleld (a11 of which are also correlated with each other) but no significant correlation with wind speed or relative humidity.

The above experiments will be continued so as to provide data for a complete year.

D. Recycling digester residues:

In recognition of the fact that supplying plants with essential nutrients is one of the more costly elements in any diomass production system, both in terms of economic and energy requirement, experiments were started last year to investigate the possibility of recycling the chemicals left in the solid and liquid residues following anaerobic digestion and methane production as a source of nutrients for new plant production. These experiments will be continued through the present contract year and beyond.

Stable, continuous anaerobic digestion of water hyacinths has now been maintained for longer than one year, with an average gas production of $0.4 \mathrm{l} / \mathrm{g}$ volatile solids, at $60 \%$ methane. The heat of combustion of water hyacinths of $3.8 \mathrm{kcal} / \mathrm{g}$ dry weight is equivalent to $4.6 \mathrm{kcal} / \mathrm{g}$ ash-free dry weight (since water hyacinths are on average $18 \% \mathrm{ash}$ ) or $19 \mathrm{~kJ} / \mathrm{g}$ volatile solids. Since pure methane has an energy content of approximately $37 \mathrm{~kJ} / 1$, the above methane production represents an average bioconversion efficiency of about $47 \%$.

Both the 1iquid and the solid digester residues were a good source of nutrients for the growth of water hyacinths. Cultures 
grown on these residues were consistently more productive than those grown in a chemically-defined enrichment medium, with an average productivity of $65 \%$ and $47 \%$ higher over the entire period for the liquid residue and the solid residue respectively. The yield of plants grown in the enrichment medium and in the liquid residue were two and three times higher, respectively, than that of the unenriched control. The growth of water hyacinths grown on solid residue was $89 \%$ of those grown on liquid residues during the nine weeks these cultures were monitored concurrently.

Water hyacinths grown on digester residues have a composition similar to those grown on a chemically-defined enrichment medium in terms of percentage ash, carbon, and nitrogen. Cultures that did not receive nutrient enrichments had reduced levels of ash and nitrogen but enhanced carbon content and carbon:nitrogen ratios. An approximate balance of the nitrogen recycled through the culture-digester-culture was made. Over the 39-week experimental period, one digester was loaded with a total of $532 \mathrm{~kg}$ wet weight of water hyacinths. This biomass was $21.3 \mathrm{~kg}$ in ash-free dry weight and contained $577 \mathrm{~g} \mathrm{~N}$. Of this $\mathrm{N}, 48 \%(276 \mathrm{~g} \mathrm{~N})$ was recovered in the liquid residue and $52 \%$ (303 $\mathrm{g} \mathrm{N}$ ) was recovered in the solid residue. In $a 11,5251$ of 11quid effluent was removed containing an average of $526 \mathrm{mg} \mathrm{N} / 1$ (a tota1 of $276 \mathrm{~g} \mathrm{~N}$ ), of which about $50 \%$ was in the form of $\mathrm{NH}_{4}^{+}-\mathrm{N}$ and the remainder was organic $\mathrm{N}$ of an unknown identity. 
Addition of this liquid effluent to cultures of water hyacinths produced $4.7 \mathrm{~kg}$ ash-free dry weight which contained $179 \mathrm{~g} \mathrm{~N}$ over a 39-week pertod, a recycling efficiency of $65 \%$. A total of $120.4 \mathrm{~kg}$ of solid residue was removed from the digester. This was equivalent to $4.6 \mathrm{~kg}$ ash-free dry weight and contained $303 \mathrm{~g} \mathrm{~N}$. Recycling $24 \mathrm{~kg}$ wet weight (equivalent to $0.9 \mathrm{~kg}$ ash-free dry weight and containing $60 \mathrm{~g} \mathrm{~N}$ ) of this material produced $1.1 \mathrm{~kg}$ ash-free dry weight containing $39 \mathrm{~g} \mathrm{~N}$ over an 8-week period, a recycling efficiency of $64 \%$

The red seaweed, Gracilaria tikvahiae, has also now been anaerobically digested for over one year, with an average gas production of $0.4 \mathrm{1} / \mathrm{g}$ ash-free dry wt, the gas containing $60 \%$ methane. Thus the efficiency of digestion and the energy value of the product gas is the same for water hyacinths and Gracilaria.

The liquid digester residue has also proved to be a highly successful source of nutrition for new growth of Gracileria, there being no significant difference between the yields of cultures grown in seawater enriched with a chemically-defined medium normally used to grow the plants or in seawater enriched with liquid digester residue containing a comparable concentration of nitrogen, unenriched controls falling to grow at all in parallel cultures. Unlike water hyacinths, however, the nutrients contained in the solid residue from Gracilarla digestion, though not as great in quantity, were not available for assimilation and new growth of seaweed. 
An approximate mass balance of the nitrogen recycled through the culture-digester-culture system was made. Over the course of the work completed to date, one digester was loaded 55 times with a total of $312.5 \mathrm{~kg}$ wet weight of Gracilaria. That biomass is equivalent to $20.2 \mathrm{~kg}$ ash-free dry weight and $0.89 \mathrm{~kg}$ nitrogen, of which $65 \%$ $(0.58 \mathrm{~kg})$ was recovered in the 3051 of 1 iquid residue and $29 \%$ $(0.26 \mathrm{~kg})$ recovered in the $116 \mathrm{~kg}$ of solid residue. Concentration of total nitrogen in the 1 iquid residue averaged $1.91 \mathrm{~g} / 1$ of which about $66 \%$ was in the form of ammonia and the remainder was organic nitrogen of unknown identity.

Addition of the liquid residue over a 292 day period to cultures of Gractlaria at a rate of $0.51 /$ week produced $0.58 \mathrm{~kg}$ afdw of seaweed containing $29.3 \mathrm{~g} \mathrm{~N}$, an uptake efficiency of $73 \%$. Overa11 efficiency through the complete cycle of seaweed-liquid residue-seaweed was $73 \%$ of $65 \%$, or $48 \%$.

The major difference between the nitrogen recycling of digester residues of water hyacinths and Gracilaria is the unavailability of the nutrient from the solid fraction of the 1atter. Visual observation of the solids from Gracilaria digestion suggests that these substances are not readily biodegradable. Indeed, one of the major constituents of Gracilaris, the hydrocolloid agar, depends for its major use in microbiological research and application upon its nonbiodegradability by most bacteria. It seems quite possible, in other words, 
that Gracilaria may be fermented to produce methane, with the recovery of at 1 east $65 \%$ of its nitrogen in the liquid residue from the digestion and available for recycling and with the bulk of its commercially-valuable product agar still available in the solid digester residue. This attractive possibility will be examined during the coming year. 


\section{Seaweed culture}

by

M. Dennis llanisak and Richard W. Stenberg

Seaweed culture in 1979 has been largely restricted to the red alga, Gracilaria tikvahiae. "ORCA" clone, isolated from the Indian River in December, 1977, has now been grown continuously in culture for nearly two years in four 2600-1iter $\left(2.4 \mathrm{~m}^{2}\right)$ aluminum tanks (Fig. 1). At least one of those cultures has been grown under the same operating conditions for the entire period, with four exchanges per day of seawater continuously enriched with $75 \mu$ moles/1 nitrate-nitrogen, $7.5 \mu$ moles/1 phosphate phosphorus and a commercial trace metal mix. Vigorous aeration is also provided to maintain the seaweed in suspension. The seaweed is removed, drained and weighed approximately every two weeks, at which time incremental growth is removed, returning the culture to a starting density that averaged $3.7 \mathrm{~kg}$ wet $\mathrm{wt} / \mathrm{m}^{2}$. The mean dally ash-free dry welght yield for each ca. two-week interval for the period January, 1978-October, 1979 is shown in Fig. 2. Dry weight is taken as $10 \%$ drained wet weight, and ash-free dry weight as $58 \%$ of total dry weight.

Also shown in Fig. 2 are mean daily water temperature and salinity and mean dally incident solar radiation, each variable having been measured daily and averaged over the period of time, usually two weeks, between seaweed harvests. Finally, photosynthetic or yield efficiency was calculated from mean ash-free dry weight and solar radiation values, assuming heat of combustion of 4.5 Calories/gram ash-free dry weight (Lapointe and Ryther, in press). Those values, representing 


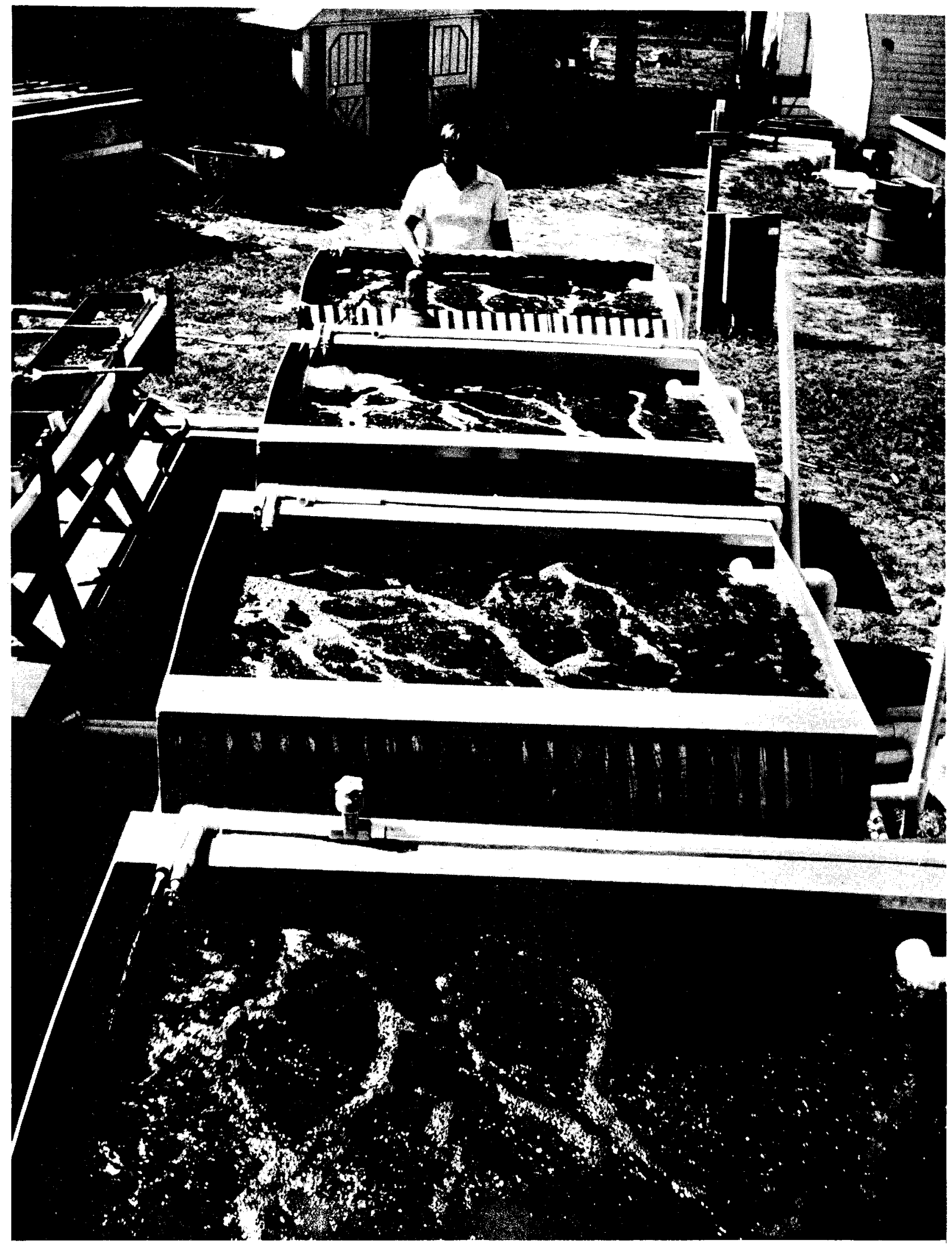

Figure 1. 2600-1iter $\left(2.4 \mathrm{~m}^{2}\right)$ aluminum tanks used to grow Gracilaria. 


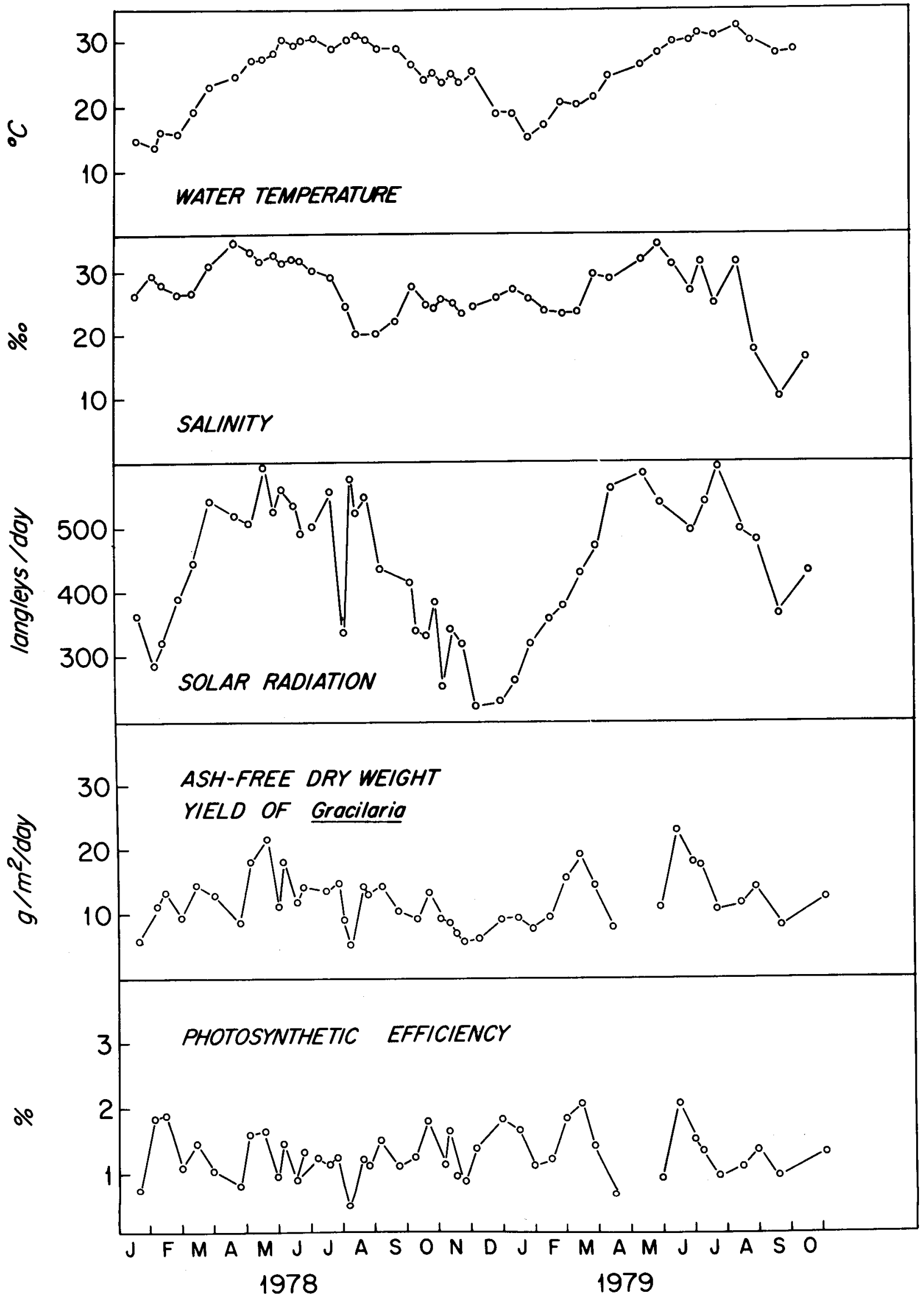

Figure 2. Annual cycle of yield and photosynthetic efficiency of Gracilaria grown in suspended culture in aluminum tanks (see Fig. 1) and related environmental variables. 
efficiency of utilization of total solar radiation, are also given in Fig. 2 .

Low yields in Apri1, 1978, were caused by temporary loss of the seawater pump and no water exchange for approximately two weeks. In April-May, 1979, the seaweeds became heavily epiphytized by filamentous brown algae and were held in shaded, non-enriched and non-flowing seawater for one month during which no yield data were obtained. Low yle1ds in September, 1979, may have resulted partly from a long period of rainy weather with low solar radiation but is believed to have been caused primarily by the very heavy rainfall accompanying Hurricane David and the resulting lowering of water salinity to a mean of $13.00 \%$ during the period $9 / 7-10 / 1$, the lowest that has been observed during the study.

Other than those periods, the Gracilaria appeared healthy and grew actively with a mean yield over the 22-month period of $12.0 \mathrm{~g}$ ash-free dry $w t / \mathrm{m}^{2}$.day $\left(20.79 \mathrm{~g}\right.$ total $\mathrm{dry} w t / \mathrm{m}^{2}$.day), almost exactly the same as reported for the one-year period (1978) in the preceding report and roughly equivalent to $44 \mathrm{ash}$-free dry tons/hectare.year (17.5 t/acre.year). Mean photosynthetic efficiency for the same period, based on total solar radiation, was $1.26 \%$ (2.52\% of the photosynthetically-available visible radiation).

There is clearly some correlation between yleld and solar radiation, though not as close as found in the earlier study in the small, screening tanks (Lapointe and Ryther, 1978), probably because density of 
the seaweed, which also has a pronounced effect on yield (Ryther et al., 1979), was not as carefully controlled in the present study.

Gracilaria yields in the small (50 1) screening tanks had previously been shown to be a function of the water exchange rate, between one and 30 exchanges per day (Lapointe and Ryther, 1978). Part of the reason for that was thought to have been the large fluctuations in such environmental factors as temperature and $\mathrm{pH}$ that occur at low exchange rates in the small cultures, particularly in summer. in the larger (2600 1) aluminum tanks, the cultures were less dependent upon rapid water exchange, with reasonably good yields resulting from an exchange rate of only four volumes/day, as discussed above. This tended to confirm the hypothesis that variable environmental conditions at slow exchange rates were adversely affecting the seaweeds in the smaller cultures, since the dally range in temperature and presumably other factors were much less in the larger volumes. However, as pointed out in the previous year, comparably good seaweed growth could not be obtained in the larger aluminum tanks with as little as one exchange/day. This is also illustrated in Table 1 for ylelds prior to July, 1979. At that time, the commercial trace metal mix that had been used in the past, which contains inorganic salts of the metals including iron ${ }^{*}$, was supplemented with a commercial EDTA-chelated iron source ${ }^{* *}$. After that, yields in the large

\footnotetext{
"Sunniland Nutrispray", Chase Chemical Co., Sanford, Flortda ** "Vigoro liquid Iron", Swift Agricultural Chemical Corp., Chicago, IL
} 
Table 1. The effect of water exchange rate and the use of chelated trace metals on the yield of Gracilaria tikvahiae.

Dates

(1979)

$7 / 11-8 / 7$
Mean yleld (ash-free dry wt $/ \mathrm{m}^{2}$.day)

A. Unchelated trace metal mix

1 Exchange/day 4 Exchanges/day

B. Chelated trace metal mix

$7 / 11-8 / 7$

$8 / 7-8 / 27$

$8 / 27-9 / 7$

$9 / 7-10 / 1$

$10 / 1-10 / 10$
6.3

14.0
10.4

11.9

11.4

8.2

13.9

7.9

7.9

12.8

12.2 
tanks at one exchange and four exchanges per day were approximately the same (Table 1). Thus trace metal availability is believed to have been the factor limiting growth at low exchange rates, a factor that had been obscured by other growth-limiting conditions in the smaller (50 1) cultures. This is an important economic consideration, since water pumping is one of the more costly operating factors in commercial seaweed cultures. New experiments will be initiated during the balance of the present contract year in which the water exchange rate will be reduced further to determine the minimum exchange that will still provide satisfactory yields with the new enrichment medium. Another important economic factor in the intensive seaweed culture system that has been employed to date is that of continuous aeration of the cultures at a rate sufficient to maintain the seaweeds in suspension. A new experiment has recently been initiated In which growth in a continuously-aerated culture is compared with that in a culture receiving no aeration at night. Results that have been obtained up to the time this report was prepared (i.e., after about two months) indicate no difference in the growth of the two cultures. If such preliminary results prove consistent, additional experiments will be carried out in which both water flow and aeration are progressively reduced, individually and in combination, unti1 a significant reduction in growth is encountered. Pulsing of water, air and nutrients for short periods of time will also be investigated. It is hoped that, by minimizing the use of such costly and energy-intensive factors as pumping water and air, 
a modified intensive culture system might be cost-effective and competitive with less intensive culture systems because of its relative high yield performance.

Studies have also been carried out on the influence of other factors possibly associated with water exchange rate on the growth of Grecilarta. Because the pll of cultures recelving only one exchange per day increased to leve1s of $9.0-10.00$ at midday, the possible effect of $\mathrm{CO}_{2}$ 1imitation was investigated both by bubbling $\mathrm{CO}_{2}$ gas through the cultures and by adding dilute HC1, in both cases reducing the $\mathrm{pH}$ to $6 \cdot 0-8.0$ and thereby making the $\mathrm{CO}_{2}$ available to the seaweeds. That experiment, carried out over four months, showed no significant enhancement of growth with added $\mathrm{CO}_{2}$ or with $\mathrm{pH}$ contro1 (Table 2).

Additional experiments were also conducted in which the water passing through the seaweed culture at the slow exchange rate of one volume/day was also rapidly (1.e., several times/hour) circulated through a large charcoal filter in order to remove any toxic organic metabolites that might have accumulated in the water at the slow exchange and thereby inhibited growth. Various technical problems were encountered in this experiment, but no improvement of growth was noted as a result of charcoal filtration of the media (Table 3). Intermediate or meso-scale experiments with Gracilaria culture were carried out in PVC-1ined earthen ponds ranging in bottom area from 10 to $20 \mathrm{~m}^{2}$, in depth from 0.4 to $0.8 \mathrm{~m}$, and in volume, from 
Table 2. Effect of bubbling $\mathrm{CO}_{2}$ gas and adding dilute $\mathrm{HCl}$ on growth of Gracilaria tikvahiae ( $\mathrm{g}$ ash-free dry $\mathrm{wt} / \mathrm{m}^{2}$.day) in cultures with one volume exchange/day.

Dates - 1979

$4 / 23-4 / 26$

$4 / 26-4 / 30$

$4 / 30-5 / 3$

5/3-5/8

$5 / 8-5 / 11$

$5 / 11-5 / 15$

$5 / 15-5 / 18$

$5 / 18-5 / 22$

$5 / 22-5 / 25$

$5 / 25-5 / 29$

$5 / 29-6 / 1$

6/1-6/4

$6 / 4-6 / 8$

$6 / 8-6 / 15$

$6 / 15-6 / 18$

$6 / 18-6 / 21$

$6 / 21-6 / 26$

$6 / 26 / 6 / 29$

$6 / 29-7 / 2$

$7 / 2-7 / 4$

$7 / 4-7 / 9$
Control

$\mathrm{CO}_{2}$ addition

10.1

16.5

17.4

15.0

18.2

16.2

16.2

15.7

10.4

16.7

21.1

18.3

19.9

18.6

15.7

21.5

6.7

7.2

13.6

11.5

5.7

3.8

7.8

11.6

13.1

10.5

5.9

7.7

12.0

13.0

7.1

17.2

11.9

17.0

12.6

14.1

14.4 
Table 3. Effect of rapid recirculation of the culture medium through charcoal filters on the growth of Gracilaria in cultures with one volume exchange/day. ( $g$ ash-free dry $w t / m^{2}$.day)

\begin{tabular}{ccc}
$\begin{array}{c}\text { Dates } \\
(1979)\end{array}$ & Charcoa1 filtration & Control \\
\hline $5 / 2-5 / 8$ & 1.3 & 3.1 \\
$5 / 8-5 / 15$ & 1.0 & 2.8 \\
$5 / 23-6 / 1$ & 4.1 & 5.2 \\
$6 / 1-6 / 14$ & 1.7 & 3.5 \\
Mean & 2.0 & 3.6
\end{tabular}


5,400 to 24,000 1iters. The purpose of these studies was to investigate and attempt to maximize yields of the seaweed in low cost, nonenergy-intensive culture systems, recognizing that such yields would undoubtedly be lower than those obtained in the highly intensive culture systems described above but also that the less intensive systems, with their lower yields, might also prove more cost-effective from both an economic and energy input:output consideration.

Various low-intensity pond culture methods have proved to be unsuccessful. These included:

1) Spray culture (Fig. 3). The seaweeds were held in plastic trays

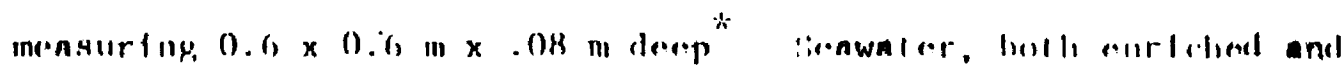
unenriched, was circulated through the ponds at one exchange/day and the water was continually pumped through conventional household shower heads and sprayed down upon the trays of seaweed that floated on the pond surface. The Gracilaria became heavily epiphytized with filamentous algae, principally Enteromorpha sp., failed to grow, and eventually died.

2) Rope culture (Fig. 4). The seaweeds were inserted into the weave of 1/2" polypropylene rope, twisted open to admit ca. 0.1-0.2 m lengths of the alga every $10 \mathrm{~cm}$ of rope and then twisted closed to hold the plant material. The ropes with seaweed at tached were suspended across the ponds along the bottom and at various depths "Nestier" trays commercially manufactured for grow-out of oyster
Vanguard Industries, Inc., Cincinnati, Ohio. 


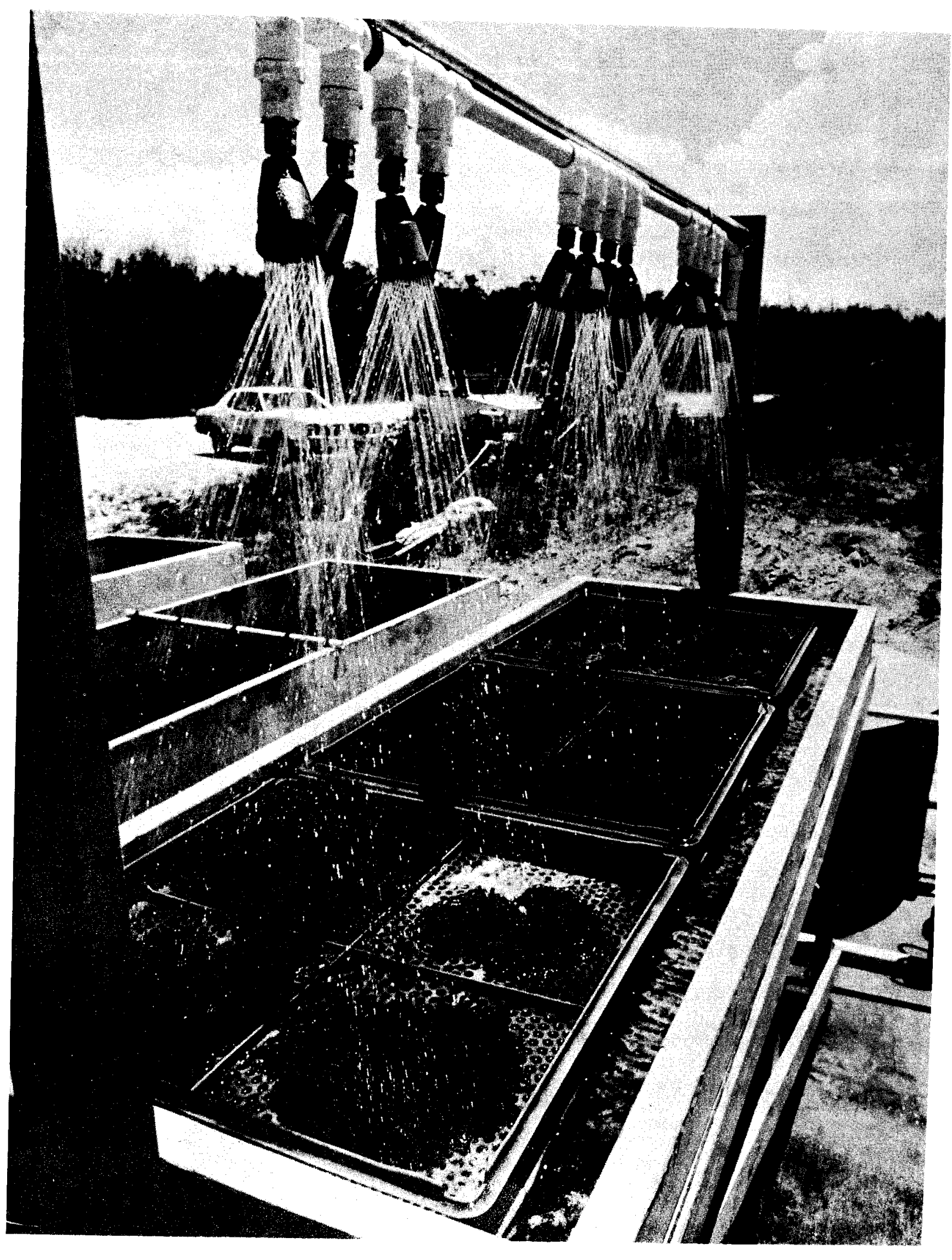

Figure 3. Spray-culture of Gracilaria. 


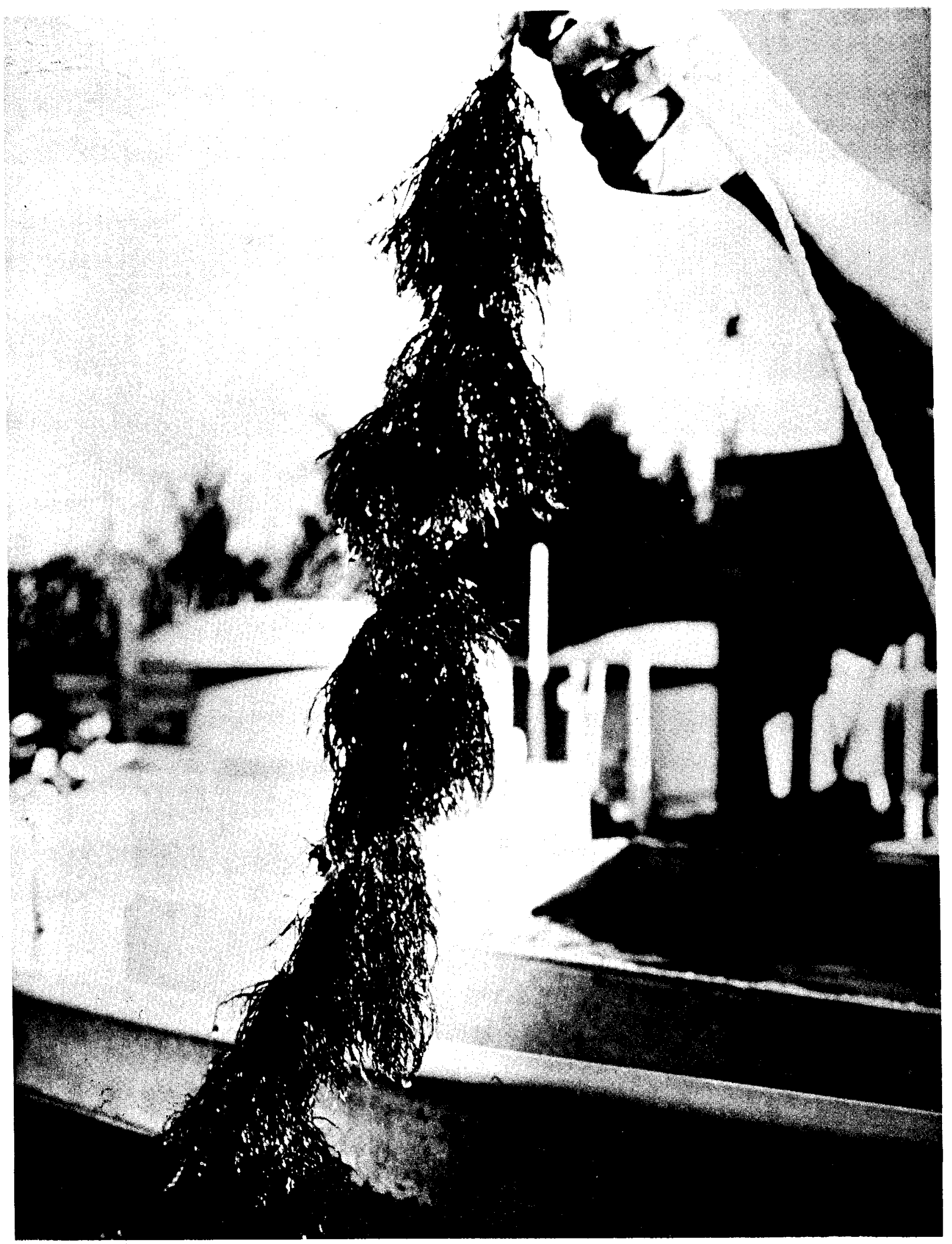

Figure 4. Rope-culture of Gracilaria. 
between the surface and bottom. Both enriched and unenriched seawater were circulated through the ponds, in different experiments, at exchange rates of one to two volumes per day. In every case the Gracilaria became heavily epiphytized, failed to grow, and eventually died.

3) Bottom culture (Fig. 5). The best success to date with non-intensive Gracilaria culture has been achieved by spreading the seaweed over the bottom of the pond through which seawater is slowly circulated. The method is essentially the same as that used for commercial Gracilaria culture in Taiwan (see Progress Report for 1978-1979, also Shang, 1976). However, variation of this technique produced rather different results, 1.e.:

A) In cultures receiving two exchanges of seawater/day, continuous enrichment of the seawater with $100 \mu$ moles/1 $\mathrm{NO}_{3}-\mathrm{N}, 10$ umoles/1 $\mathrm{PO}_{4}-\mathrm{P}$ and trace metals resulted in severe infestation with epiphytes, low yields of Gracilaria, and eventual loss of the culture.

B) Cu1tures receiving two exchanges of unenriched seawater/day were provided with "pulsed" nutrients. Every two weeks, the flow of seawater was stopped for two days at which time $36.4 \mathrm{~g} \mathrm{NaNO}_{3}, 5.1 \mathrm{~g}$ $\mathrm{Na}_{2} \mathrm{HPO}_{4} \cdot \mathrm{H}_{2} \mathrm{O}, 30 \mathrm{ml}$ trace metal mix (Sunniland), and $15 \mathrm{ml}$ chelated iron (Vigoro liquid iron) per $\mathrm{m}^{2}$ of pond bottom were added. Based on nitrogen as an index, that amount of nutrient addition was calculated to be sufficient to support a mean growth rate over the two-week period of $12 \mathrm{~g}$ ash-free $\mathrm{dry} w \mathrm{wt} / \mathrm{m}^{2}$.day. In addition the 


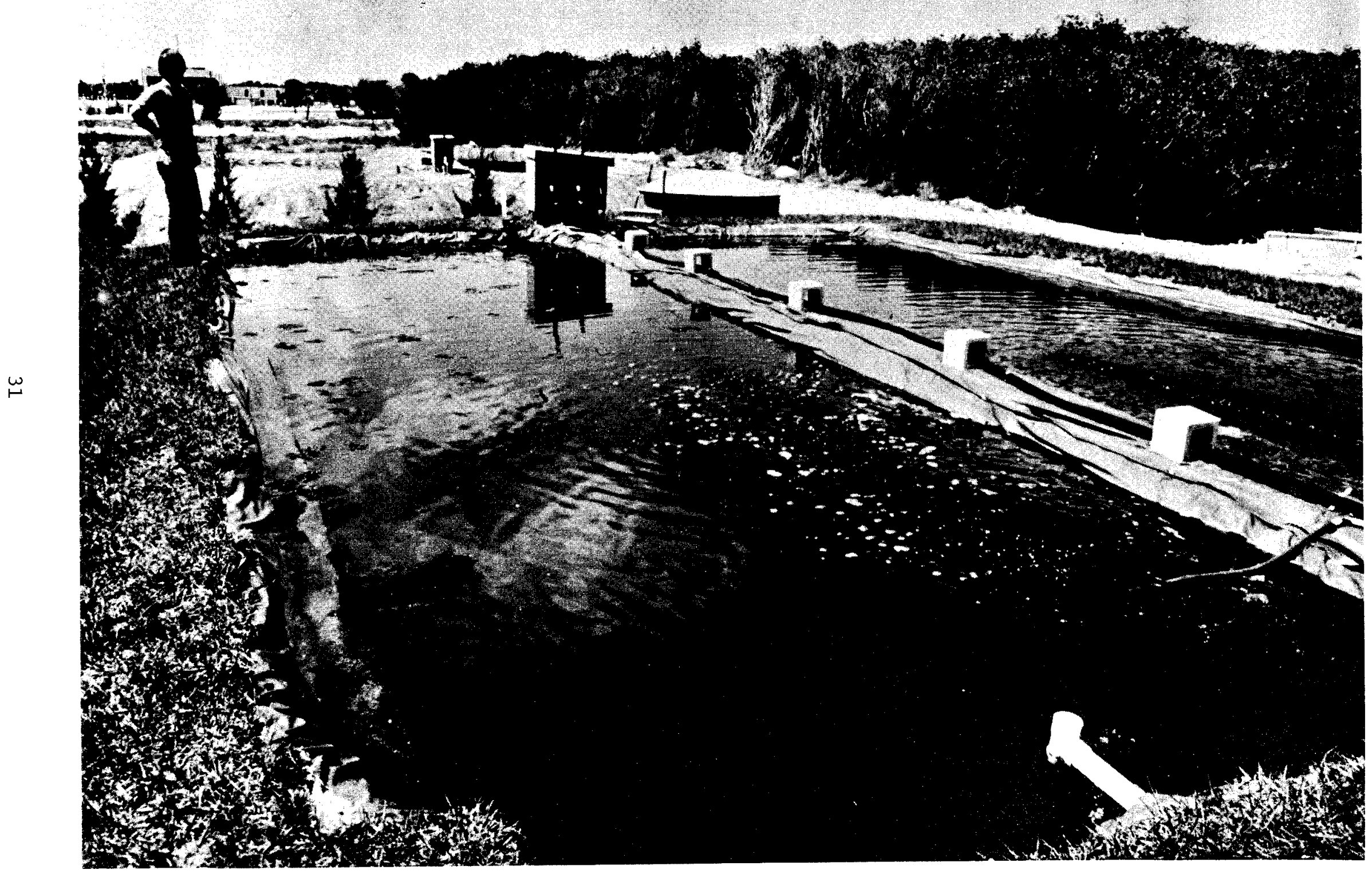

Figure 5. PVC-lined ponds used for pond-bottom culture of Gracilaria. 
nutrients present in the seawater that would pass through the cultures during the two weeks was calculated to be sufficient to support an addition production of $6 \mathrm{~g}$ afdw $/ \mathrm{m}^{2}$. day for a total of $18 \mathrm{~g} \mathrm{afdw} /$ $\mathrm{m}^{2} \cdot \mathrm{day}$.

The cultures that were enriched with "pulsed" nutrients have remained, for the most part, free of epiphytes and have grown successfully since the method was first employed.

C) Shallow, nutrient-pulsed ponds $(40 \mathrm{~cm})$ supported poor growth of Gracilaria in summer (June-September) with a mean yield of $0.5 \pm 0.2 \mathrm{~g}$ afdw/m $\mathrm{m}^{2}$.day but much better growth in spring and fall (March-May, OctoberNovember), with mean yield of $4.5 \pm 0.7 \mathrm{~g} \mathrm{afdw} / \mathrm{m}^{2}$.day. Deep ponds $(80 \mathrm{~cm})$ produced more consistent ylelds that were intermediate in value, averaging $3.2 \pm 0.9$ and $2.9 \pm 0.8 \mathrm{~g} \mathrm{afdw} / \mathrm{m}^{2}$. day in springfall and in summer, respectively.

i) The use of and-1oam bottom on the PVC pond liners, considered an essential ingredient in the Taiwanese Gracilaria culture operations (see 1978-79 report), had no effect on yields of Gracilaria in the present experiments.

E) At two volume exchanges per day, the ponds became strongly thermally stratified in summer and the incoming seawater did not mix with the pond volume. Gentle aeration from an airline that extended longitudinally the length of the bottom on its bottom provided mixing of the seawater around and through the seaweed but did not move or disturb the plants themselves. Such aeration proved 
essentlal for growth of Gracilaria in summer but has not been found necessary in fall, when thermal stratification of the ponds disappeared.

Tentative conclusions that may be drawn to date on the best operating procedures for non-intensive shallow pond culture of Gracilaria are:

1) Slow exchange (1-2 volumes/day) of unenriched seawater.

2) Pulsed nutrient addition every two weeks for ca. 2 days with seawater flow stopped.

3) Use of shallow water depth $(0.4 \mathrm{~m})$ in fall, winter and spring and greater depth $(0.8 \mathrm{~m})$ in summer.

4) Gentle aeration in summer.

5) Although unconfirmed by controlled experimentation, the use of a relatively high density of seaweed (ca. $5 \mathrm{~kg}$ wet $\mathrm{wt} / \mathrm{m}^{2}$ or more) appears to be beneficial in pond culture practices, though the reason for this is not yet understood and will be studied further.

Mean yields from the more successful pond cultures during the period of March-October, 1979 have been roughly $3 \mathrm{~g}$ afdw/m $\mathrm{m}^{2}$.day, equivalent to some $10 \mathrm{t} / \mathrm{ha}$.year or about $4 \mathrm{t} / \mathrm{acre}$ year.

In September, 1979, two PVC-1ined, concrete-wall ponds each measuring $77 \times 12 \mathrm{~m}\left(10,000 \mathrm{ft}^{2}\right.$ or roughly one-quarter acre) were completed (Fig. 6). These ponds are intended to serve as demonstration units for aquatic plant production on a scale large enough that engineering design evaluation and economic and energy cost-effectiveness 


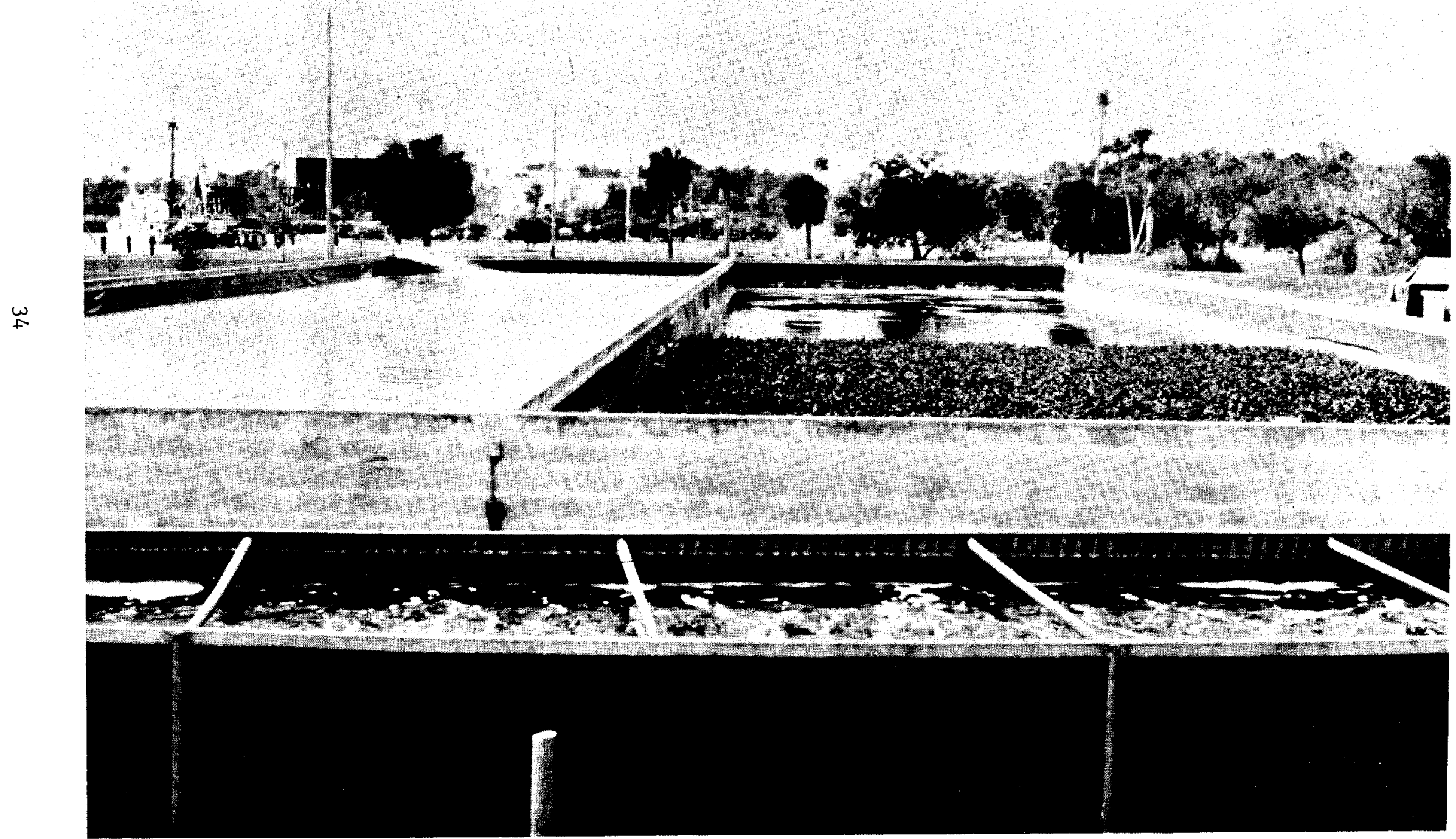

Figure 6. One-quarter-acre $\left(10,000 \mathrm{ft}^{2}\right)$ concrete ponds used for Gracilaria culture (left) and water hyacinth culture (right). 
analyses may be carried out. One pond is designated for Gracilaria cultivation and was stocked in early November, 1979 with ca. one ton of the seaweed collected from the Indian River. A1though it was initially planned to use the "ORCA" clone of $\mathrm{G}$. tikvahiae that has been successfully maintained in culture for'two years, it was estimatad that over a year's time would be required to produce the necessary material from the available experimental cultures to fully stock the large demonstration unit.

During the balance of the present contract year, an attempt will be made to grow Gracilaria from the wild stock in the large pond, using the techniques that have been developed to date in the shallow experimental ponds over the past six months.

References:

Lapointe, B. E. and J. H. Ryther. 1978. Some aspects of the growth and yield of Gracilaria tikvahiae in culture. Aquaculture 15: 185-193.

Lapointe, B. E. and J. H. Ryther. (In press) The effects of nitrogen and seawater flow rate on the growth and biochemical composition of Gracilaria foliifera $v$. angustissima in mass outdoor cultures. Botanica Marina.

Ryther, J. H., J. A. DeBoer and B. E. Lapointe. 1979. Cultivation of seaweeds for hydrocolloids, waste treatment and biomass of energy conversion. Proc. 9th Internat. Seaweed Symp., Santa Barbara, CA, August 20-27, 1977. Ed. by Arne Jensen and Janet R. Stein, Science Press, Princeton. pp. 1-16.

Shang, Y. C. 1976. Economic aspects of Gracilaria culture in Taiwan. Aquaculture 8: 1-7. 


\section{Freshwater macrophyte culture}

by

Thomas A. DeBusk

In contrast to the effort in seaweed culture, where several important problems remained to be resolved, relatively little time was devoted in 1979 to freshwater macrophyte culture. A few studies that had been in progress at tht end of the past contract year were completed and some new problem areas were addressed, but the major questions had, it was believed, already been answered. Eichhornia crassipes, the water hyacinth, remains the most promising freshwater plant for biomass production by a wide margin over other species that have been studied, with the constraint, however, that it is tropical and unable to grow at temperate latitudes.

A comparison of water hyacinth yields in the culture facility at Harbor Branch Foundation with that of a natural stand of the plants in a euthropic fire ditch adjacent to the Kissimmee River near Okeechobee, Florida (see Progress Report for 1978-79), that was started in April. 1978, was continued through August, 1979 (Fig. 1). Only in late winter and early spring were yields from the two locations comparable. For the rest of the year, the growth of the cultures at Harbor Branch Foundation, where the plants were exposed to a continuous flow of enriched we11 water, was several times that of the natural populations. Thus the premise made in the previous report, that water hyacinth yields obtained at the HBF aquaculture facility approach or equal the maximum potential biomass production of the species at the latitude and in the climate of central Florida, is further substantiated. 


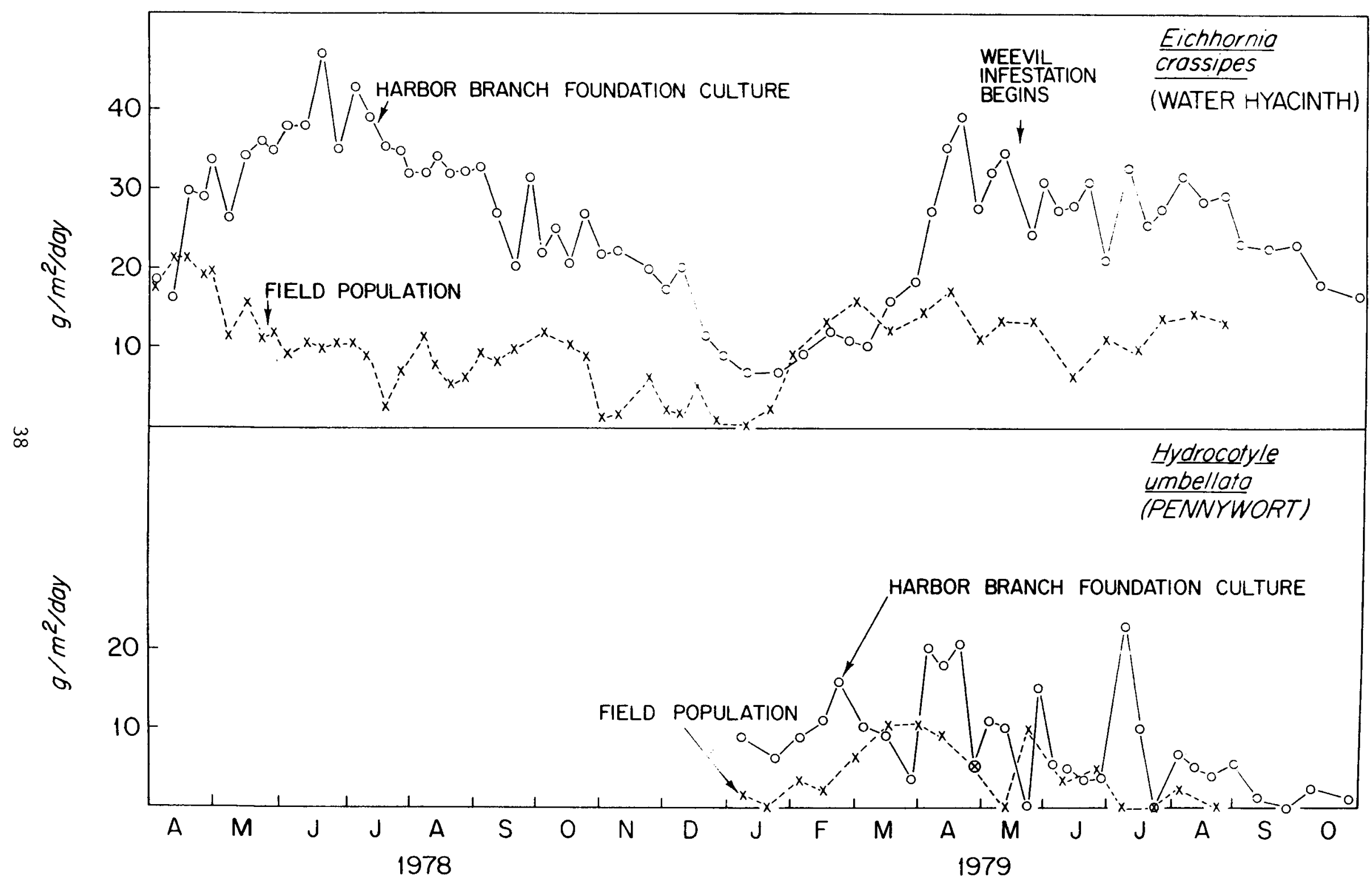

Figure 1. Yields of water hyacinth (Eichhornia crasslpes) and pennywort (Hydrocotyle umbellata) in the field and at the Harbor Branch Foundation aquaculture facility. 
The previously reported average yield of water hyacinth over a one-year period from $12 / 21 / 77-12 / 13 / 78$ was $19.8 \mathrm{~g}$ ash free dry weight $/ \mathrm{m}^{2}$.day, equivalent to 72 tons/ha.year ( $29 \mathrm{t} / \mathrm{acre}$ year). For the period 3/30/78-3/30/79, the mean production was $25.7 \mathrm{~g}$ afdw/ $/ \mathrm{m}^{2}$.day or $94 \mathrm{t} / \mathrm{ha}$ year ( $37 \mathrm{t} / \mathrm{acre}$ year), about one-third higher than the earlier values. The difference between the two estimates reflects differences in the levels of solar radiation and temperature for the periods, particularly in winter, and is an example of the kind of year-to-year variability that may be expected, particula rly for a plant growing near the northern limit of its distribution.

In the first experiments with the cultivation of water hyacinths, reported in the 1977-78 Progress Report and referred to in the 197879 Progress Report, the plants grown in a culture medium of we 11 water enriched with nitrate, phosphate and a commercial, inorganic trace-metal mix ${ }^{*}$ eventually became chlorotic and stopped growing. The problem was partly resolved by spraying the trace metal solution directly onto the foliage of the plants. It had earlier been reported by Phillips (1978) that water hyacinths grew much more successfully in a culture medium containing chelated iron than in an inorganic iron salt $\left(\mathrm{FeCl}_{3}\right)$. This observation was subsequently confirmed when the culture medium at Harbor Branch Foundation was supplemented with

\footnotetext{
*Sunniland "Nutri-spray", Chase Chemical Co., Sanford, FL.
} 
a commercial preparation of chelated Lron (le-lit)TA) "lable 1 shows the growth of water hyacinths during a four-month experiment in which the plants were grown in the original culture medium (i.e., with Sunniland "Nutri-spray" trace metal mix added to the water), with the same trace metal mix sprayed on the foliage of the plants, and with the chelated iron added to the original enrichment medium in the water. The results clearly show that inorganic iron $\left(\mathrm{FeCl}_{3}\right)$ added to the water is unavailable to the plants, presumably because tt prectpitates as an insoluble hydroxide or other compounds. The Iron was equally available to the plants, however, if sprayed on the leaves as $\mathrm{FeCl}_{3}$ or if added to the water as Fe-EDTA.

In May, 1979, the water hyacinths in culture at Harbor Branch Foundation became infested with weevils of the genus Neochetina, either or both $\underline{N}$. eichhorniae or $\underline{N}$. bruchi. These insects, native to South America and host specific to water hyacinth, have been Introduced to Florida by the U.S. Department of Agriculture specifically for the purpose of water hye cinth control (B. D. Perkins, unpublished reports, DeLoach, 1976; DeLosch and Cardo, 1976). According to Perkins, the weevil is unlikely to kill and eradicate large stands of water hyacinths by itself, but the insect is able to stress and debilitate the plants sufficiently that other control methods may then prove more effective.

*Vigoro "Liquid-Iron", Swift Agricultural Chemical Corp., Chicago, IL. 
Table 1. (irowth or lifchhornia crassipes (waler hyacinth) with (1) an Inorganic trace metal mix added to the water, (2) the same trace metal mix sprayed on the plant foliage, and (3) the inorganic trace metal mix and a chelated iron supplement both added to the water (growth in $g$ afdw $/ \mathrm{m}^{2}$.day).

\begin{tabular}{|c|c|c|c|}
\hline $\begin{array}{l}\text { Dates } \\
(1979)\end{array}$ & $\begin{array}{l}\text { (1) Inorganic trace } \\
\text { metals in water }\end{array}$ & $\begin{array}{l}\text { (2) Inorganic trace } \\
\text { metals sprayed }\end{array}$ & $\begin{array}{l}\text { (3) Inorganic trace } \\
\text { metals plus } \\
\text { chelated iron } \\
\text { in water }\end{array}$ \\
\hline $1 / 19-1 / 30$ & 5.0 & 4.8 & 6.4 \\
\hline $1 / 30-2 / 6$ & 2.9 & 4.7 & 5.8 \\
\hline $2 / 6-2 / 14$ & 3.1 & 5.1 & 4.1 \\
\hline $2 / 14-2 / 20$ & 11.8 & 8.0 & 10.5 \\
\hline $2 / 20-3 / 1$ & 8.4 & 7.5 & 9.8 \\
\hline $3 / 1-3 / 8$ & 9.8 & 15.2 & 17.0 \\
\hline $3 / 8-3 / 21$ & 2.3 & 5.2 & 6.1 \\
\hline $3 / 21-3 / 28$ & 1.8 & 19.1 & 12.6 \\
\hline $2 / 28-4 / 4$ & 2.5 & 15.1 & 19.8 \\
\hline $4 / 4-4 / 11$ & 1.8 & 17.3 & 19.4 \\
\hline $4 / 11-4 / 18$ & 0.0 & 20.2 & 20.6 \\
\hline
\end{tabular}


The weevil infestation of the llarbor Branch Foundation water hyacinth cultures visibly affected the plants and may have quantitatively reduced their yields. As soon as the problem was diagnosed, the plants were aerially sprayed with a systemic organophosphate insecticide (Cygon $2 \mathrm{E}^{*}$ ) which eventually brought the infestation under partial control. However, it has proved impossible to eradicate the pest completely by insecticide application and the latter is therefore currently used routinely to keep growth of the weevils checked. Some reduction in the growth of hyacinths from the time the weevil infestation was first noted to the present has been observed, with yields some 12\% lower than for the comparable period in 1978 ( $27.3 \mathrm{vs} .31 \mathrm{~g}$ afdw $/ \mathrm{m}^{2}$.day). The reduction may be caused by the Insects, possibly by the insecticide application, or it may result from other causes such as natural year-to-year varlability. However, weevil control now appears to be a continuous problem that will, at the least, adversely affect the economics of water hyacinth blomass production.

Previous studies of the other freshwater macrophytes Lemna minor (duckweed) and Hydrilla verticillata had shown them to be poor competition with water hyacinths as candidate species for biomass production. The only freshwater plant that had been studied up to the time of the 1978-79 Progress Report that appeared possibly to rival Eichhornia was the pennywort, Hydrocotyle umbellata, attractive because it resembles water hyacinth in habit but appeared

\footnotetext{
*American Cyanamid Co., Princeton, NJ.
} 
to be somewhat more cold-tolerant and would perhaps survive and grow in climates that would not support water hyacinth.

Hydrocotyle has now been grown in culture at the Harbor Branch Foundation for most of one year, from January through October, 1979. It is apparent from the yield data (Fig. 1) that the earlier promise of the species was 111 -founded. Mean ash-free dry weight yield for the above 10 -month period was only $7.9 \mathrm{~g} / \mathrm{m}^{2}$.day, about onethird that of water hyacinth for the same period.

In the preceding report, the mean annual yield of duckweed (Lemna minor) was given as $2.6 \mathrm{~g}$ afdw/m $\mathrm{m}^{2}$.day $(3.7 \mathrm{~g}$ total dry wt/ $m^{2}$.day). It was postulated that higher yields of that small floating species could not be obtained because the plants completely covered the water surface at an extremely low density after which further growth would result in self-shading and other adverse effects of over-crowding (DeBusk et al., in press). Subsequently, Culley et al. (in press) reported that yields of duckweed could be increased by a factor of more than threefold if the new growth were harvested daily rather than weekly, thereby maintaining the plants at a lower mean density. A variation of that experiment was later carried out at Harbor Branch Foundation. The yield of cultures measured once at the end of 4-10 day growth periods was compared with that of cultures from which 13 , 19 and $42 \%$ of the daily growth was also harvested each day, thereby maintaining them at progressively lower average densities throughout the growth period. The results of that experiment (Table 2) show no 
Table 2. Ylelds of duckweed grown In concrete vaults with a continuous flow of enriched we11 water (residence 0.5 days) in cultures with plants weighed once at the end of the growth perlod compared with cultures in which various fractlons of the stocked biomass were also harvested each day (yields in $g$ afdw $/ \mathrm{m}^{2}$.day).

Duration of Exp.

Unharvested

Harvested dally

(days)

(at $13 \%$ of stocked biomass)

\begin{tabular}{ccc}
8 & 6.4 & 5.3 \\
8 & 5.7 & 5.5 \\
8 & 3.7 & 3.6 \\
\hline Mean & -3.3 & 4.8
\end{tabular}

(at $19 \%$ of stocked biomass)

\begin{tabular}{rrr}
8 & 4.0 & 2.9 \\
8 & 5.3 & 4.7 \\
8 & 5.7 & 5.9 \\
10 & 4.1 & 4.4 \\
10 & 4.6 & 4.9 \\
\hline Mean & 4.7 & 4.6
\end{tabular}

(at $42 \%$ of stocked biomass)

\begin{tabular}{ccc}
5 & 5.1 & 5.0 \\
4 & 4.6 & 3.8 \\
5 & 3.7 & 3.9 \\
\hline Mean & $\frac{3.7}{44}$ & 4.2
\end{tabular}


significant difference between yields of the unharvested cultures and those from which increasing fraction of the incremental growth was harvested daily, thus failing to reproduce the results of Culley et $a 1$.

Water lettuce, Pistia stratiotes, has been grown for a short time in late 1979, from October 7 until November 26, when this report was prepared (Fig. 2). Its cultivation was part of a related study of the chemical composition of various aquatic weeds, but the species has some attractive features including a high protein content (mean nitrogen content $=4.53 \%$, nearly twice that of water hyacinth). Pistia is another introduced tropical species, like water hyacinth, and is reputedly even more sensitive to cold than is Eichhornia, but it appears to be reasonably productive and could have other advantages over hyacinths (i.e., it is smaller and perhaps more easily managed, harvested, processed, etc.).

Yields of Pistia are shown in Table 3 over the two months it has been in culture, with the plants held at four densities by harvesting incremental growth at each weighing. Culture methods are essentially the same as those previously described for water hyacinths. The best yields, at a density of $160 \mathrm{~g}$ afdw $/ \mathrm{m}^{2}$, averaged $14.4 \mathrm{~g} \mathrm{afdw} / \mathrm{m}^{2}$.day, about the same as the yields of water hyacinths during the same perfod of time (data not available in this report). As the data show, the yields have decreased by nearly half over the the two-month fall 


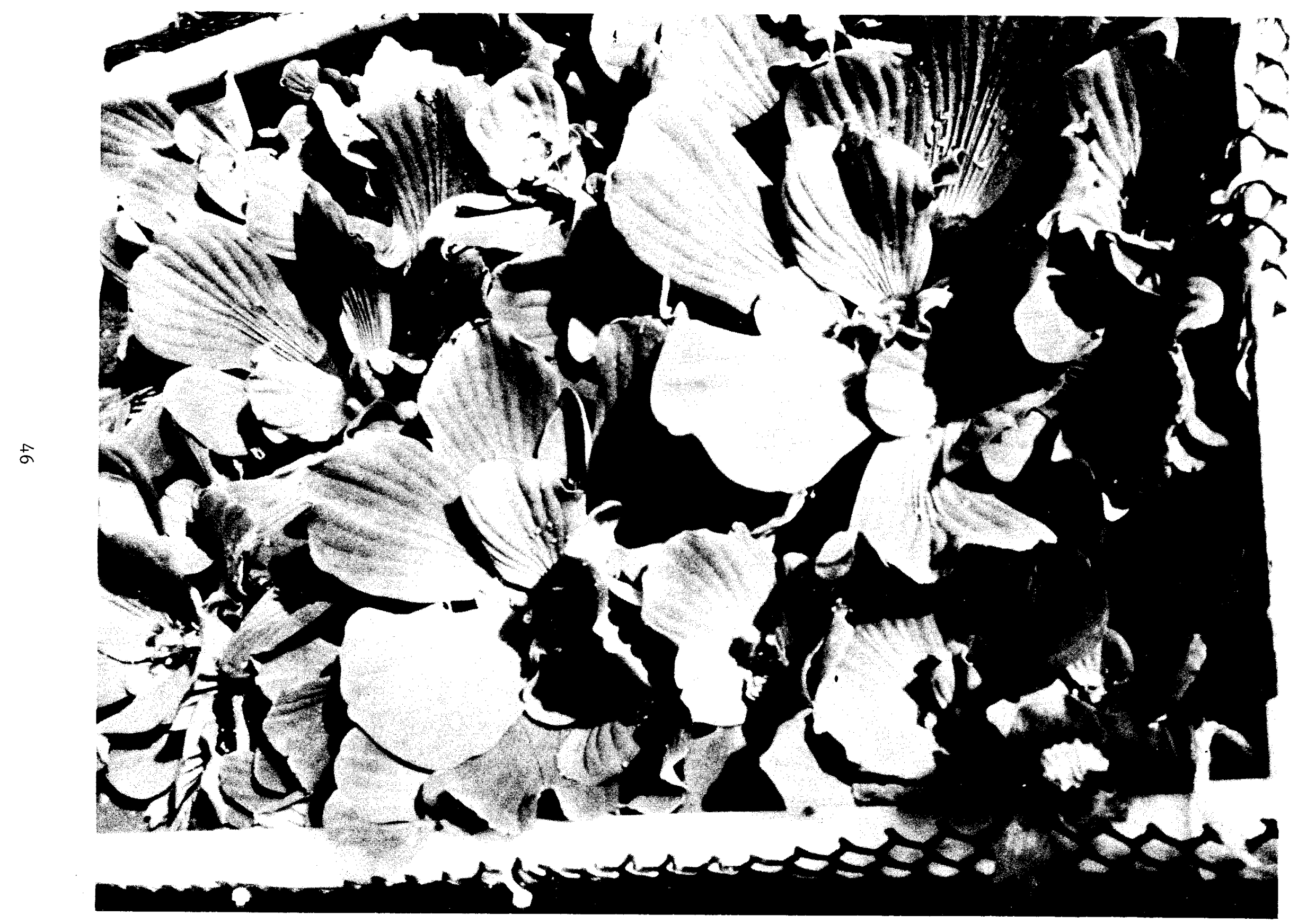

Figure 2. Water lettuce (Pistia stratiotes) in culture at Harbor Branch Foundation. 
Table 3. Ylelds of water lettuce, Pistia stratiotes, grown at four densities. Yields in $g$ ash-free dry $\mathrm{wt} / \mathrm{m}^{2}$. day averaged over the indicated periods.

\begin{tabular}{ccccc} 
Dates & \multicolumn{5}{c}{ Density } & $(\mathrm{g}$ afdw/m & \\
$(1979)$ & 32 & 96 & 160 & 256 \\
& & Yield & & \\
$10 / 7-10 / 15$ & 11.8 & 17.4 & 19.2 & 16.1 \\
$10 / 16-10 / 21$ & 12.6 & 18.2 & 18.8 & 15.2 \\
$10 / 22-10 / 29$ & 13.5 & 17.3 & 19.9 & 19.6 \\
$10 / 30-11 / 5$ & 10.9 & 13.0 & 16.1 & 12.9 \\
$11 / 6-11 / 12$ & 8.9 & 10.3 & 9.7 & 9.0 \\
$11 / 13-11 / 19$ & 4.6 & 6.1 & 5.2 & 2.8 \\
$11 / 20-11 / 26$ & 9.5 & 11.7 & 11.7 & 11.2 \\
Mean & 10.3 & 13.4 & 14.4 & 12.4 \\
\hline
\end{tabular}

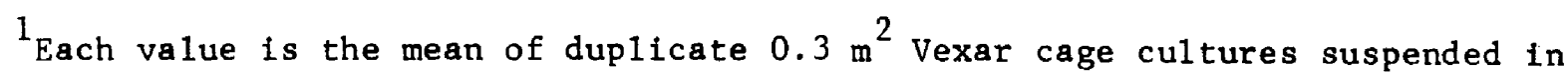
vaults containing enriched flowing wel1 water. 
period. Its cultivation will be continued, if it survives the winter, for an entire year and its annual yield compared with that of water hyacinth and other freshwater macrophytes.

A second PVC-1ined, concrete-wa11, one-quarter-acre $\left(10,000 \mathrm{ft}^{2}\right)$ pond, contiguous with that to be used for Gractlaria culture, was also completed in the late summer of 1979 (see Chapter II, Fig. 6) and will be used as a demonstration unit to assess the economic and energy cost:benefit ratio of a water-hyacinth-based energy farm with digester residue and treated wastewater serving as its nutrient supply.

The pond was stocked with approximately three tons (wet wt) of water hyacinths collected from a wild population during SeptemberOctober, 1979, and the plants had grown to the extent that they covered approximately half of the pond surface at the time this report was prepared (Fig. 3). 


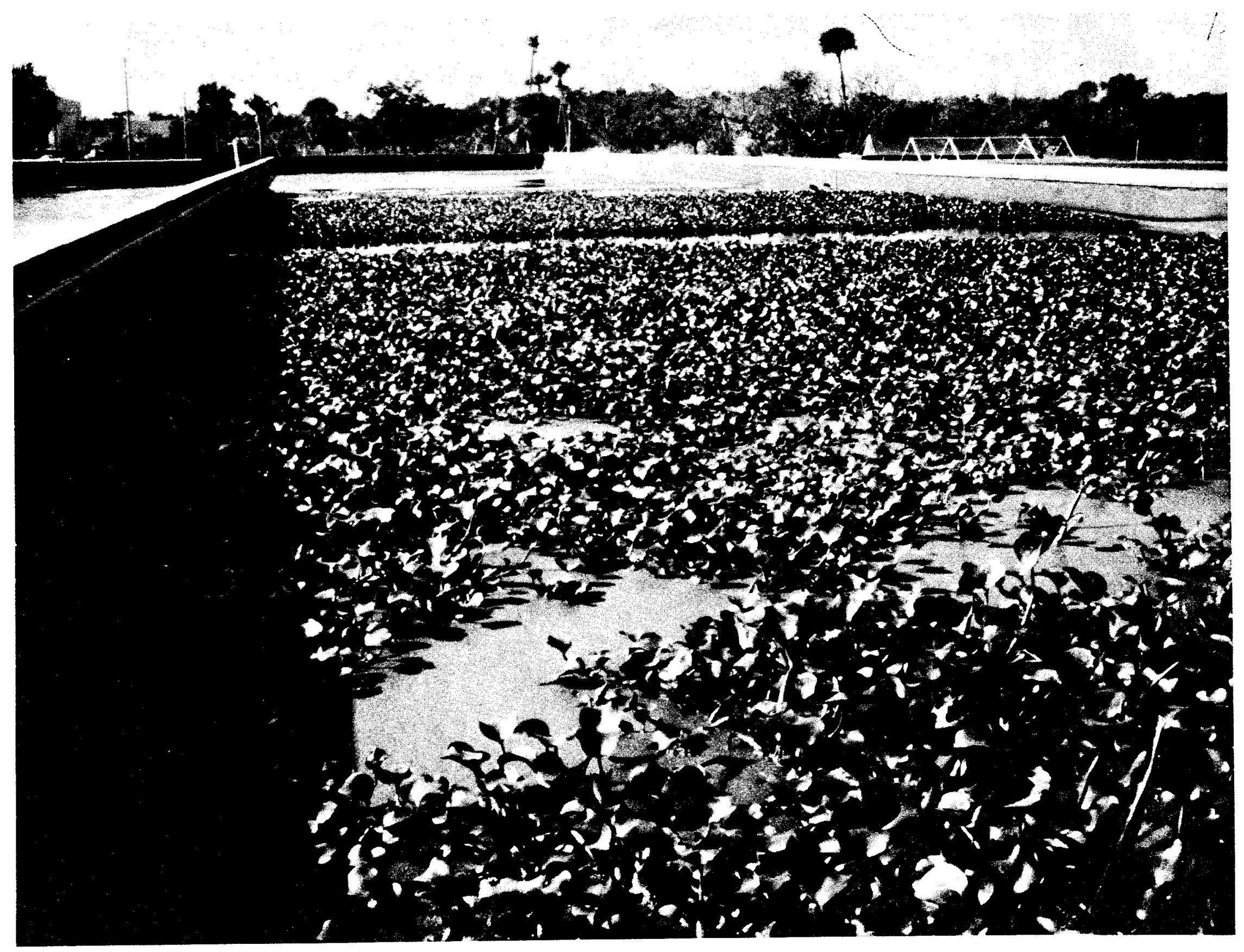

Figure 3. One-quarter-acre pond partia11y filled with water hyacinths. 
DeBusk, T. A., M. D. Hanisak, L. D. Williams and J. H. Ryther. (In press) Primary production of some freshwater macrophytes: annual cycle and density effects. Aquatic Bot.

DeLoach, C. J. 1976. Neochetina bruchi, a biological control agent of water hyacinth: Host specificity in Argentina. Ann. Ent. Soc. Am. 69: 635-642.

DeLoach, C. J. and H. A Cordo. 1976. Life cycle and biology of Neochetina bruchi, a weevil attacking water hyacinth in Argentina, with notes on $\underline{N}$ eichhorniae. Ann. Ent. Soc. Am. 69: 643-652.

Culley, D. D., L. C. Standifer, Z. Said, R. W. Myers, E. A. Epps and S. A. Boney. (In press) Effect of harvest rate, waste loading and stocking density on the yield of duckweeds. Proc. Ann. Mtg. World Mariculture Soc., Honolulu, January, 1979.

Perkins, B. D. (Unpublished ms.) Host specificity and biology studies of Neochetina eichhorniae Warner, an insect for the biological control of water hyacinths. Aquatic Plant Mgt. Lab., Agr. Res. Serv., U.S.D.A., 3205 S.W. 70th Avenue, Ft. Lauderdale, FL 33314.

Perkins, B. D. (Unpublished ms.) Enhancement of effect of Neochetina elchhorniae for biological control of water hyacinths. Aquatic Plant Mgt. Lab., Agr. RES. Serv., U.S.D.A., 3205 S.W. 70th Ave., Ft. Lauderdale, FL 33314.

Phillips, J. M. (Unpublished ms.) Controlled environmental systems for the production of vascular aquatic plant biomass for conversion to 1iquid and gaseous fuel. Env. Res. Lab., U. Arizona, Tucson, AZ. 
IV. Effects of seasonality, nitrogen form and availability and plant stand density on the chemical composition and nutritive value of water hyacinth (Elchhornia crassipes).

by

Craig S. Tucker

Introduction

Preliminary experiments on biogas production during anaerobic decomposition of the water hyacinth, Eichhornia cressipes, indicated that the rate and ultimate volume of gas produced is related to the nutritive quality of the plants. This was expected as other microbially mediated processes such as digestion of plant material by ruminant herbivores (Van Soest, 1966) and the decomposition of organic material in solls (Alexander, 1961) are highly dependent upon such factors as cellulose, lignin, and nitrogen content.

Results of studies on the mineral content (Boyd and Vickers, 1971; Knlp1ing et a1., 1970) and proximate composition (Boyd, 1969a; Royd and Blackburn, 1970) have Indicated that water hyacinth is generally of good nutritive quality. Average values for cellulose, non-structural carbohydrate, and protein content compare favorably with many high quality terrestrial forages. However, considerable variation in the composition of water hyacinths is found from site to site (Boyd, 1969a), and there are indications of considerable seasonal variation (Boyd and Blackburn, 1970). Studies conducted during the past year have dealt with factors which may affect the nutritive quality of water hyacinths. The effects of season, nitrogen fertility and stand. density were investigated. 


\section{Materials and Methods}

Seasonal study:

Two stands of water hyacinths were sampled every two weeks from November 15, 1978 to October 10, 1979. S1te 1 was located in a sma11 canal adjacent to the Kissimmee River, near Okeechobee, Florida. Site 2 was a small $\left(10,0001,30 \mathrm{~m}^{2}\right)$ PVC-1ined pond located on the aquaculture facility at Harbor Branch Foundation near Fort Pierce, Florida. Nutrient concentrations and water levels were subject to natural fluctuations at site 1 . At site 2, nutrient levels were maintained as constant as possible by the inflow of an enriched nutrient solution at two-volume-turnovers per day. The approximate composition of the inflowing solution is given in Table 1.

At both sites three $1-\mathrm{m}^{2}$ Vexar cages were filled with water hyacinths to a density of $10 \mathrm{~kg}$ wet $\mathrm{wt} / \mathrm{m}^{2}$. At two-week intervals the cages were weighed after being drained of excess water for 4 minutes and the incremental growth removed. A sample of 2 or 3 plants was welghed, dried at $70^{\circ} \mathrm{C}$ for 48 hours and reweighed to provide a ratio of dry weight to wet weight. An additional three plants were retained for chemical analyses. These plants were thoroughly washed in deionized water and dried for 48 hours at $70^{\circ} \mathrm{C}$. After drying, the plants were ground to a fine powder in a food blender and stored for later analysis. 
Table 1. Approximate composition of enriched culture solution flowing into pond at site 2 .

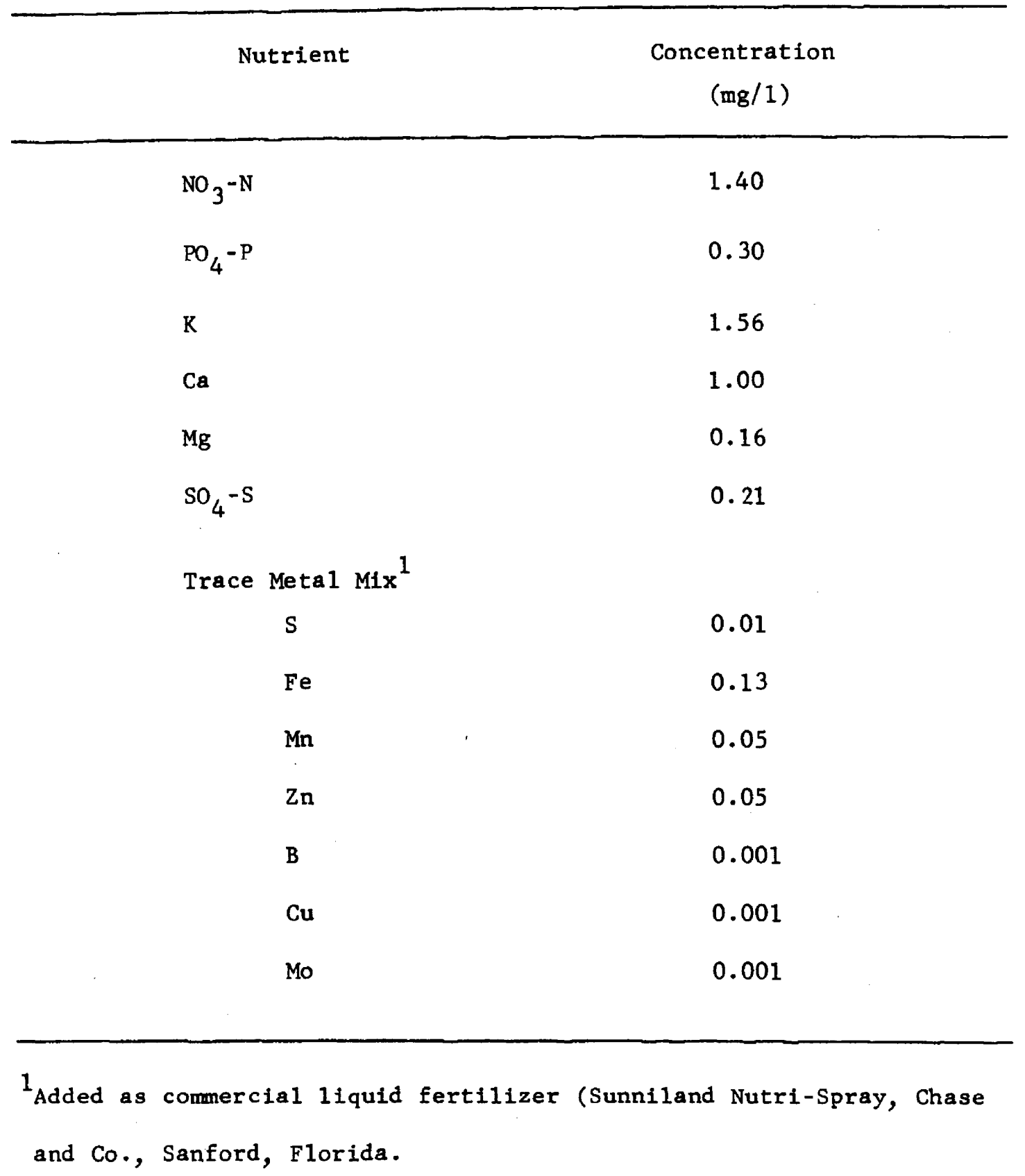


Nitrogen fertility study:

Work was conducted at the aquaculture facility at the Harbor Branch Foundation during the spring of 1979. Water hyacinths were cultured outdoors in 201 styrofoam containers having a surface area of $0.11 \mathrm{~m}^{2}$. The composition of the nitrogen-free nutrient solution used is given in Table 2. To 201 of the nitrogen-free media, a concentrated solution of $\mathrm{NaNO}_{3}$ or $\mathrm{NH}_{4} \mathrm{Cl}$ was added to give initial nitrogen concentrations of $14,7,3.5$, and $1.75 \mathrm{mg} / 1$. Each treatment was duplicated. Containers were drained and refilled with fresh nutrient solution twice weekly.

On April 12, two small water hyacinths (approximately $30 \mathrm{~g}$ wet wt each) were placed in each container. Within one month plants covered the water surface in all treatments. On May 10 plants were harvested back to an initial density of $7.25 \mathrm{~kg}$ wet wt/m $\mathrm{m}^{2}$. At twoweek intervals plants were removed, drained of excess water for 4 minutes, weighed and the incremental growth removed. Samples of 2 or 3 plants for dry matter determination were weighed, dried at $70^{\circ} \mathrm{C}$ for 48 hours and rewelghed.

On Iune 21 all plants were harvested after the final weighing. 'Three plants from each container were washed in deionized water, dried, ground to a fine powder, and stored for later analysis. Density study:

This study was conducted at the Harbor Branch Foundation aquaculture facility during August and September, 1979. Water hyacinths 
Table 2. Composition of nitrogen-free culture medium used in experiments on nftrogen nutrition of water hyacinth.

Nutrient

$\mathrm{K}$

$\mathrm{Ca}$

$\mathrm{Mg}$

$S$

$\mathrm{Fe}^{1}$

Mn

B

$\mathrm{Zn}$

$\mathrm{Cu}$

Mo

\section{Concentration}

$(\mathrm{mg} / 1)$

3.1

23.5

8.0

4.9

6.4

5.0

0.5

0.19

0.05

0.03

0.005

${ }^{1}$ Iron was added as $1 \mathrm{mg} \mathrm{Fe} / 1$ as $\mathrm{FeCl}_{3} \cdot 6 \mathrm{H}_{2} \mathrm{O}$ and $4 \mathrm{mg} \mathrm{Fe} / 1$ as EDTA chelated iron. 
were cultured outdoors in six $0.3-\mathrm{m}^{2}$ Vexar cages, three each in two 9001 cement vaults. Vaults were drained and refilled weekly with fresh nutrient solution, the composition of which is given in Table 3. In each vault a series of three water hyacinth densities was established. Initial densities were 5,10 , and $20 \mathrm{~kg}$ wet $\mathrm{wt} / \mathrm{m}^{2}$. Plants were cultured for eight weeks. Each week the cages were removed from the vault, drained of excess water for 4 minutes and weighed. The incremental growth was removed, returning plant density to the correct initial value. At the end of eight weeks, three plants from each cage were washed in deionized water, dried and ground.

Chemical analyses:

Total nitrogen was determined using a Perkin-Elmer 240 elemental analyzer. Ce11-wall fraction was estimated as neutral detergent fiber (Van Soest and Wine, 1967) and lignocellulose as acid detergent fiber (Van Soest, 1963). Crude neutral and acid detergent fiber values were corrected for ash content and artifact lignin (Van Soest, 1965). Nonstructural carbohydrates were extracted in $0.2 \mathrm{~N} \mathrm{H}_{2} \mathrm{SO}_{4}$ (Smith et al., 1964) and measured using the Shaeffer-Somogyi copperiodometric titration procedure (Heinze and Murneek, 1940). Ash values were obtained by igniting the plant material at $550^{\circ} \mathrm{C}$ for 4 hours in a muffle furnace. Inorganic nitrogen was extracted from $0.25 \mathrm{~g}$ of dry plant material in $50 \mathrm{ml}$ of distilled water for 24 hours at $5^{\circ} \mathrm{C}$ (Larsen and Tensen, 1957). Solutions were then filtered through 
Table 3. Composition of culture medium used in experiments on effect of stand density on water hyacinth composition.

\begin{tabular}{|c|c|}
\hline Nutrient & $\begin{array}{c}\text { Concentration } \\
(\mathrm{mg} / 1)\end{array}$ \\
\hline $\mathrm{NO}_{3}-\mathrm{N}$ & 14.0 \\
\hline $\mathrm{PO}_{4}-\mathrm{P}$ & 3.1 \\
\hline $\mathrm{K}$ & 23.5 \\
\hline $\mathrm{Ca}$ & 8.0 \\
\hline $\mathrm{Mg}$ & 4.9 \\
\hline $\mathrm{SO}_{4}^{-\mathrm{S}}$ & 6.4 \\
\hline $\mathrm{Fe}^{1}$ & 4.0 \\
\hline \multicolumn{2}{|c|}{ Trace metal mix ${ }^{2}$} \\
\hline $\mathrm{s}$ & 1.5 \\
\hline $\mathrm{Fe}$ & 2.0 \\
\hline $\mathrm{Mn}$ & 0.75 \\
\hline $\mathrm{Zn}$ & 0.75 \\
\hline B & 0.02 \\
\hline $\mathrm{Cu}$ & 0.01 \\
\hline Mo & 0.009 \\
\hline
\end{tabular}

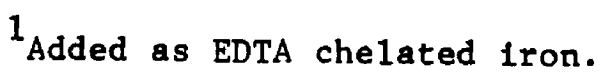

2 Added as commercial liquid fertilizer (Sunniland Nutri-Spray, Chase and Co., Sanford, Florida). 
Whatman No. 42 filter paper and diluted to $100 \mathrm{ml}$. Ammonia in the extract was determined by the phenate method (American Public Health Association, 1971). Nitrate was reduced to nitrite by cadmiumcopper reduction which was then diazotized and measured colorimetrically (Strickland and Parsons, 1972). The analyses for ammonia and nitrate in water samples were conducted as for the extracts. Soluble orthophosphate was determined by the ascorbic acid method (American Pub1ic Hea1th Association, 1971).

\section{Results and Discussion}

Seasonal study:

Obviously only results obtained at site 2 reflect the effects of season alone on the composition of water hyacinths. Both nutrient concentration (Fig. 1) and water flow varied during the year at site 1. During the week of December 26 through 31 all aquatic plants naturally occurring in the canal at which site 1 was located were mechanically harvested and piled along the bank by conservation workers. Subsequent decomposition of the harvested plants and leaching by rainfall resulted in increased concentrations of nutrients during lanuary and February. Other than this one period of elevated nutrient concentrations, the water at site 1 was rather nutrient deficient, especially when compared to the artificially enriched system at site 2. The summer (June-September) average for total inorganic nitrogen at site 1 was approximately $0.06 \mathrm{mg} / 1$ and that for 


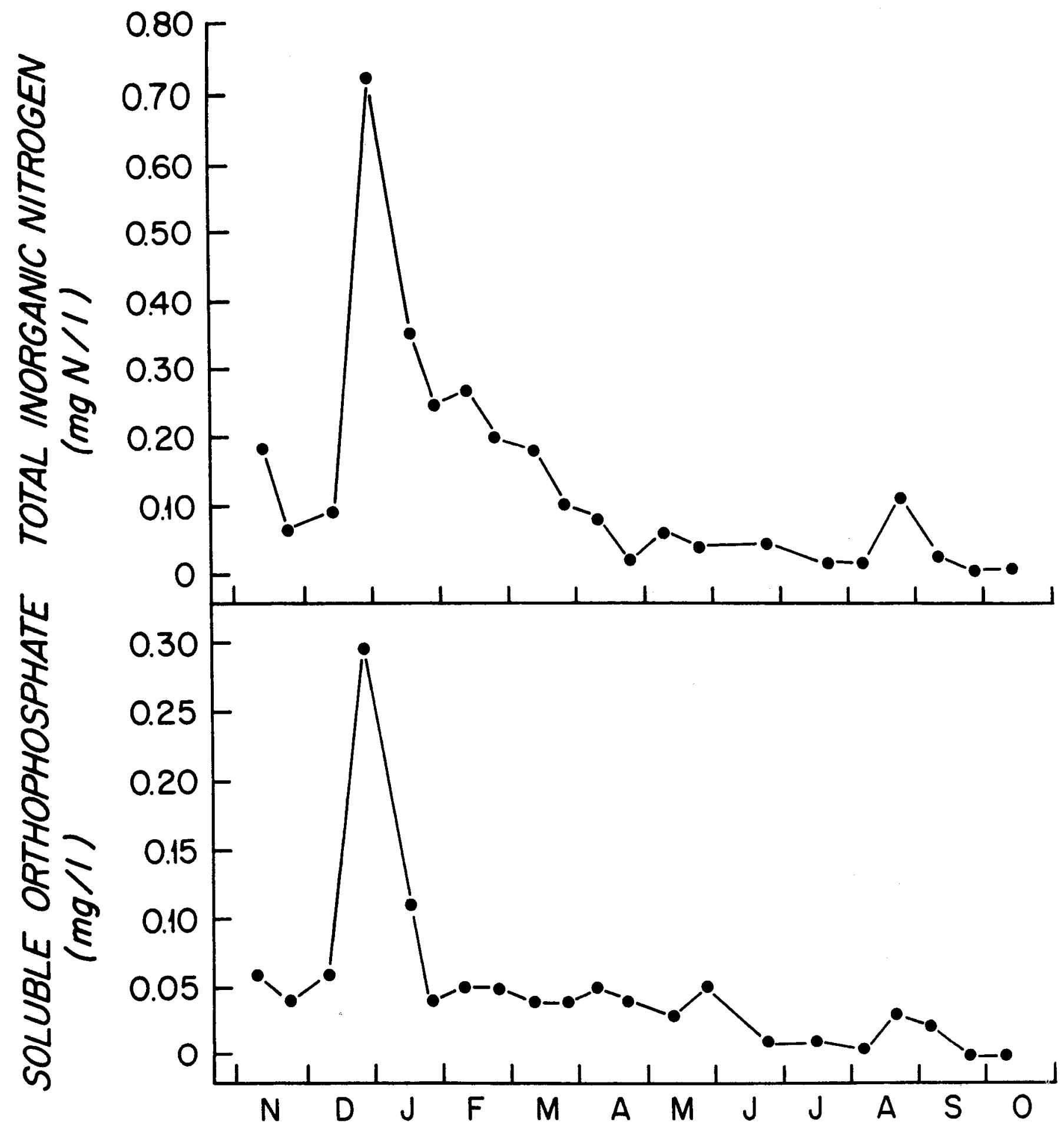

Figure 1. Concentrations of total inorganic nitrogen $\left(\mathrm{NO}_{3}-\mathrm{N}+\mathrm{NO}_{2}-\mathrm{N}+\mathrm{NH}_{4}-\mathrm{N}\right)$ and soluble orthophosphate occurring at site 1 during the study period. 
soluble orthophosphate $0.02 \mathrm{mg} / 1$. This is to be compared to 0.84 $\mathrm{mg} / 1$ tota 1 inorganic nitrogen and $0.22 \mathrm{mg} 1$ orthophosphate as site 2 . The ash-free dry weight yield of water hyacinths from the two sites reflects the difference in nutrient availability (Fig. 2). Seasonal average yield for site 1 was 8.1 and that for site $2,17.6 \mathrm{~g}$ ash-free dry $w t / \mathrm{m}^{2} / \mathrm{day}$.

Definite seasonality of growth was evident at both sites (Fig. 2). Lowest rates of growth occurred during late December, Tanuary, and February. The effect of water quality was seen even at this time however, as the yield of water hyacinths at site 2 was significantly higher than that at site 1 during December and January.

Changes in the composition of water hyacinths at site 2 followed a seasonal trend similar to that for growth. As the rate of growth decreased during November and December, tota 1 nitrogen increased (Fig. 3). At the same time lignocellulose and nonstructural carbohydrate levels decreased (Fig. 4). Maximum nitrogen content for plants at site 2 was $3.6 \%$ on February 8 . Minimum nonstructural carbohydrate content (6.3\%) occurred on February 26 and minimum 1ignocellulose (23\%) on March 22 . As photosynthetic rates and dry matter production increased starting in mid-March, nitrogen levels decreased and carbohydrate fractions increased. Nitrogen levels continued to decrease until early May, approximately the same time at which yield ceased increasing. Levels of lignocellulose increased until well into the sumer, reaching a maximum value of $33 \%$ of dry wt on August 14 for site 2 . 


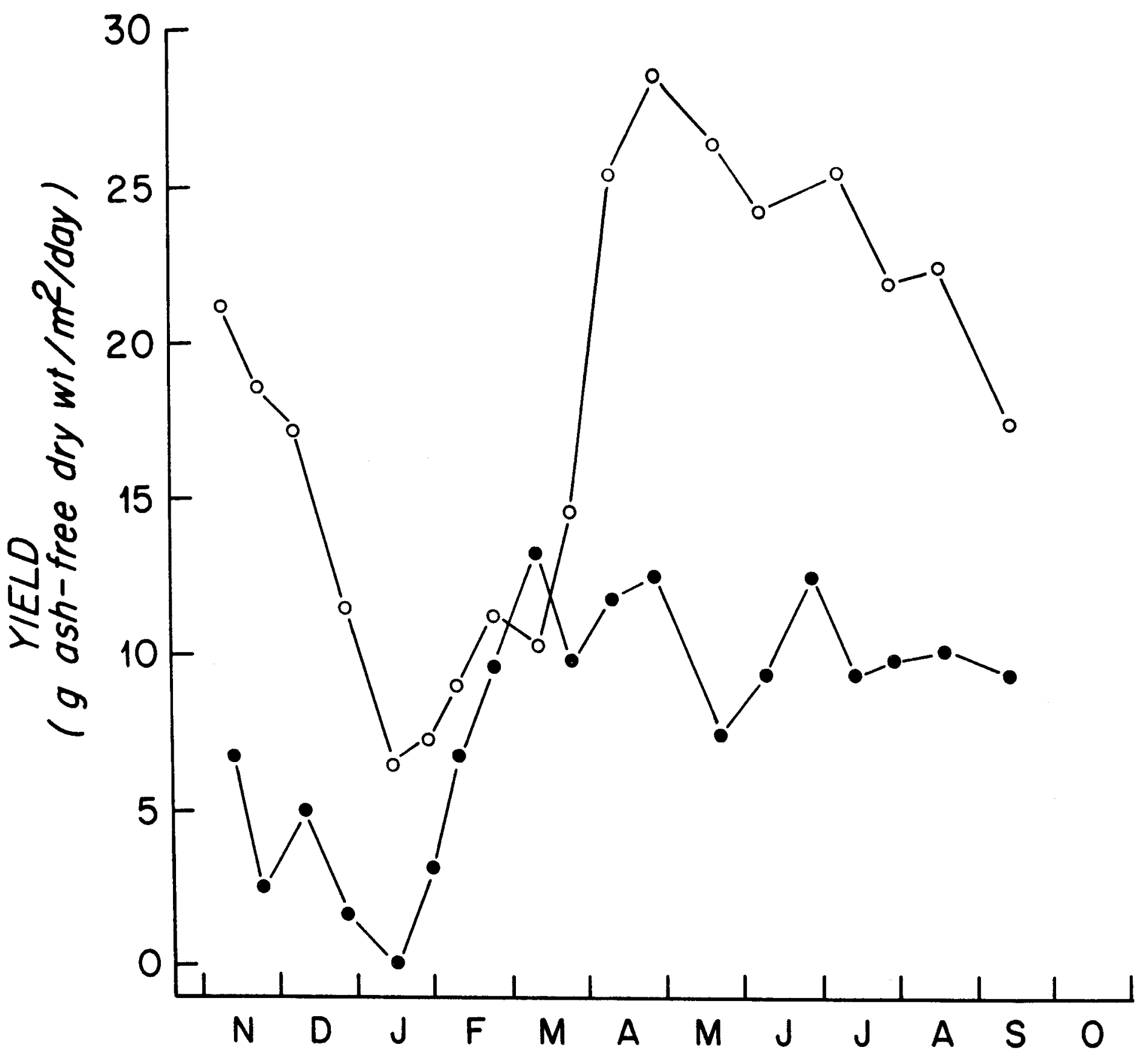

Figure 2. Mean daily yields of water hyacinths at site 1 (closed circles) and site 2 (open circles). 

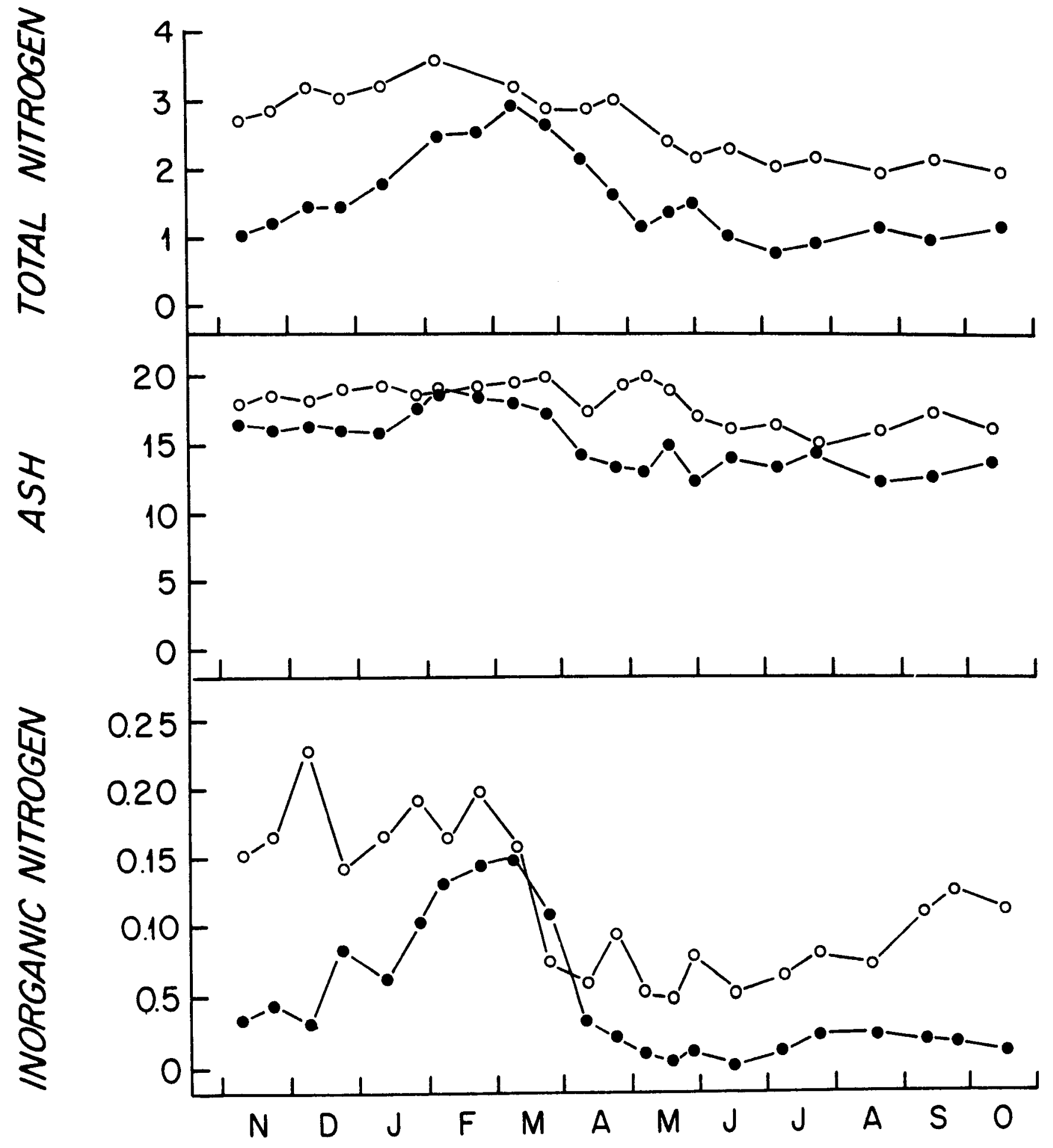

Figure 3. Seasonal changes in total nitrogen, ash and inorganic nitrogen content of water hyacinths from site 1 (closed circles) and site 2 (open circles). Values are as \% of dry weight. 


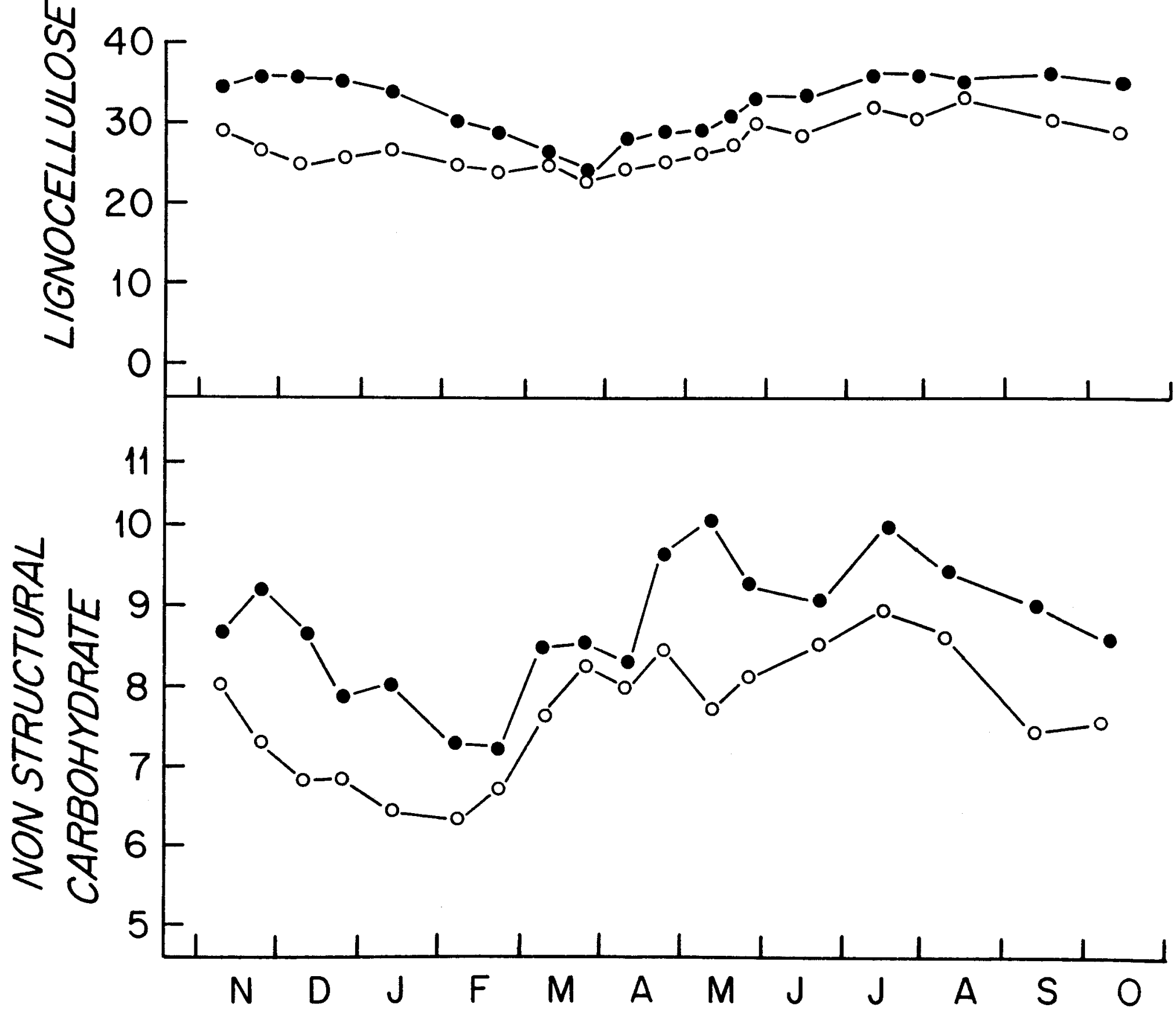

Figure 4. Seasonal changes in lignocellulose and nonstructural carbohydrate content of water hyacinths from site 1 (closed circles) and site 2 (open circles). Values are as $\%$ of dry weight. 
Boyd and Blackburn (1970) found water hyacinth crude protein (\% nitrogen $\times 6.25$ ) increased and cellulose content decreased as the growing season progressed. The plants examined were from a natural stand and undoubtedly subject to varlations in nutrient availability. Trends in composition of water hyacinths in this type of situation may not truly represent seasonal variation only. In a later study, Boyd (1976) cultured water hyacinths in a pond fertilized biweekly with inorganic nutrients and found decreasing tissue nitrogen content during the summer months. The conditions under which these plants were grown would produce plants which would more nearly reflect only seasonal variation in composition.

Many terrestrial forages (Russe11, 1973) and rooted emergent aquatic plants (Boyd, 1969b, 1970) al so show a decrease in nitrogen content as the growing season progresses and nitrogen supplies in the soil or sediment are diminished. In the present study nitrogen availability remained constant throughout the year at site 2 , and results are more comparable to those of Nichols and Keeney (1976). The total nitrogen content of Myriophyllum spicatum was lowest in the summer despite the fact that avallable nitrogen in the sediments was highest at that time. Apparently nitrogen accumulation continues during periods of low growth rates in the winter leading to increased levels of nitrogen in the plant. As the season progresses and nitrogen 
supplies remain constant, nitrogen uptake may not keep pace with the vigorous spring and summer dry matter production. Changes in the amount of inorganic nitrogen extracted from tissues of dried water hyacinths (Fig. 3) are particularly interesting in this respect. The increasing levels of inorganic nitrogen during the winter months Indicate that uptake of nitrogen was occurring at a rate somewhat faster than it could be incorporated into organic products. As photosynthetic rates increased in the spring, increased amounts of carbohydrate were made avallable for synthesis of organic nitrogen compounds and inorganic nitrogen content of plants rapldly decreased.

Two growth forms of water hyacinth are recognized, small plants with swollen petioles and larger plants with elongated, nonswollen petioles (Penfound and Ear1, 1948; Musil and Breen, 1977a). Generally the larger plants occur in dense communities where growth is restricted to a vertical direction only. Although water hyacinths were harvested back to a density of $10 \mathrm{~kg}$ wet $w / \mathrm{m}^{2}$ every two weeks, the final density of plants immediately before each harvesting was much greater during the summer months than winter due to the greater rate of growth. As the density achieved prior to harvesting increased during the spring and summer, plant growth was increasingly restricted to a vertical direction only. The percentage of lignocellulose (Fig. 4) increased as the need for more supportive tissue arose during the spring and summer . 
Changes in the composition of water hyacinths from site 1 were very similar to those occurring at site 2 . The increase in nutrient concentration during January and February (Fig. 1) had noticeable effects however. Varlation in total and inorganic nitrogen content was much greater at site 1 due to the increased availability of nitrogen in the winter. Similarly, ash content was seen to increase markedly at this time. Lignocellulose content also decreased during this perfod even though yield was increasing. In contrast to the case at site 2 where nutrient availability remained constant, the decreasing lignocellulose content at site 1 may have been the result of increased nitrogen availability. As nitrogen supplies Increase, carbohydrates are converted to organic nitrogen compounds and less is available for deposition as cell wall material (Russell, 1973).

Nitrogen fertility study:

In the present study nitrogen fertility is expressed as the average amount of nitrogen made available per unit plant biomass per day. For example, the highest initial nitrogen concentration used was $14 \mathrm{mg} / 1$. At this concentration $280 \mathrm{mg} \mathrm{N}$ was added to 201 containers twice a week, or an average of $80 \mathrm{mg} \mathrm{N} /$ day was available to the hyacinths. The initial biomass of hyacinths in each container averaged $0.044 \mathrm{~kg}$ dry weight. The available nitrogen for the highest level of nitrogen fertility is thus $1.82 \mathrm{~g} \mathrm{~N} / \mathrm{kg}$ dry wt/day. Similarly, available nitrogen for the other treatment levels were $0.91,0.46$ and $0.23 \mathrm{~g} \mathrm{~N} / \mathrm{kg}$ dry wt/day. 
lixpressing nitrogen fertflity in this manner rather than in concentration units, such as $\mathrm{mg} / 1$, allows for comparison with other culture systems. The same total nitrogen can be made available to a fixed biomass of plants by doubling the volume of the culture solution and halving the total amount of nitrogen added. Similar variations in plant biomass and frequency of nutrient addition can be made without changing the average amount of nitrogen available per plant biomass per day. However, this ignores the limiting role of diffusion of nutrients at high volumes and low concentrations. Also ignored is the effect of extreme fluctuations of nutrient concentration on plant growth when culture solution volume is sma11 compared to plant density or when the nutrient solution is changed infrequent ly.

At all treatment levels virtually all of the nitrogen added to culture solution's was taken up by the plants. Less than $0.01 \mathrm{mg} \mathrm{N} / 1$ remained at any level of either $\mathrm{NO}_{3}-\mathrm{N}$ or $\mathrm{NH}_{4}-\mathrm{N}$ when sampled immediately prior to changing nutrient solutions.

The relationships between nitrogen availability and total and ash-free dry matter yield of water hyacinth are presented in Fig. 5 . Analysis of vartance indicated significant differences in total dry matter yield due to level of nitrogen availability $(P<0.05)$. However, when expressed on an ash-free basis, dry matter yields did not differ $(P>0.05)$ whether plants were cultured on $\mathrm{NO}_{3}-\mathrm{N}$ or on $\mathrm{NH}_{4}-\mathrm{N}$. This is in disagreement with Musil and Breen (1977b) who suggested 


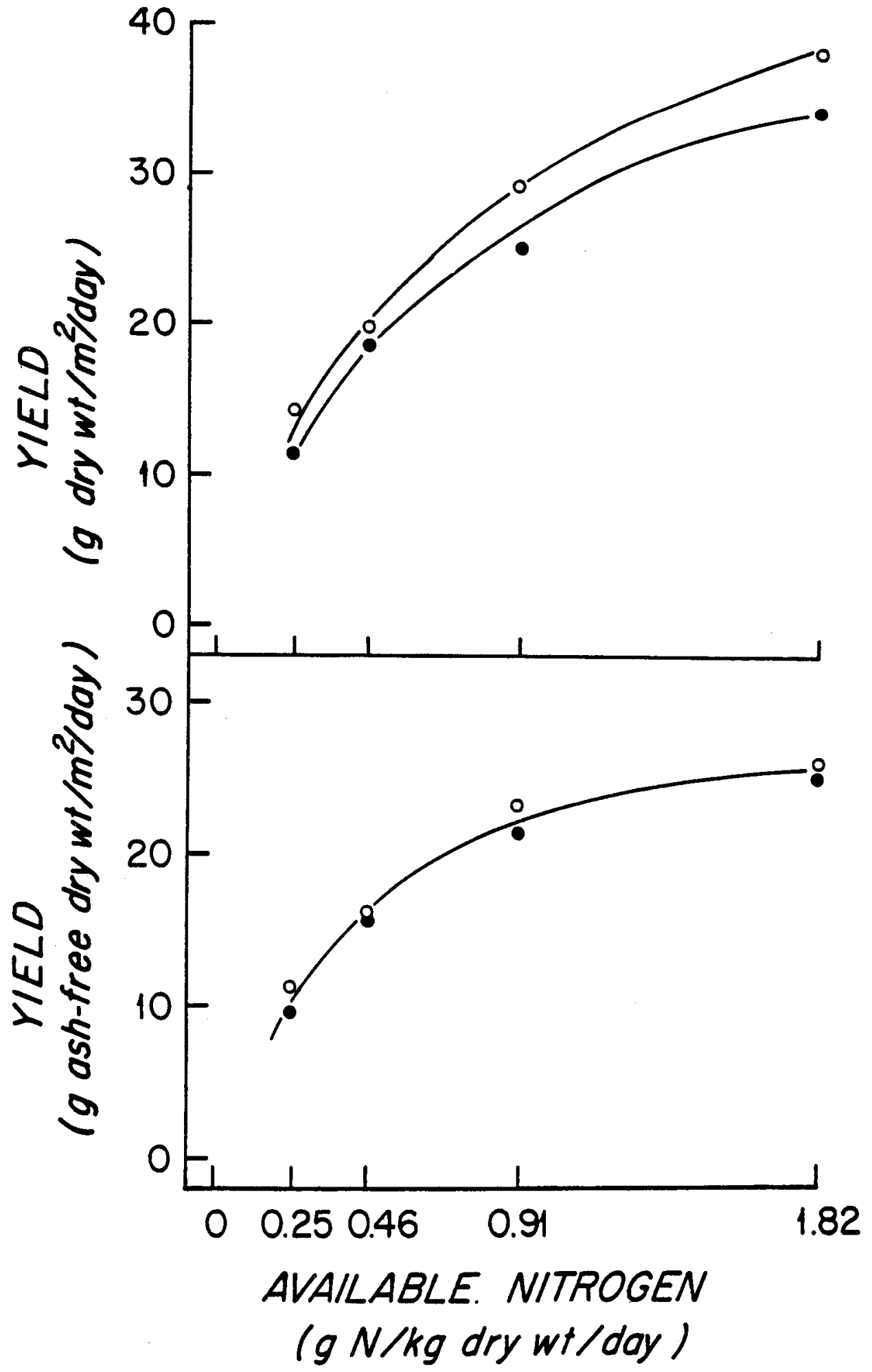

Figure 5. Mean daily dry welght and ash-free dry weight yields of water hyacinth cultured on four levels of nitrogen availability. Nitrogen was supplied as either ammonium (closed circles) or nitrate (open circles). 
that $\mathrm{NH}_{4}-\mathrm{N}$ cannot serve as a nitrogen source for the growth of water hyacinth. No interaction of the two factors, form and level of nitrogen, was indicated $(P>0.05)$ for efther total or ash-free dry matter yield.

Little nitrification of the $\mathrm{NH}_{4}^{+}$added to culture solutions occurred. Analysis of water samples taken at daily intervals after addition of $\mathrm{NH}_{4} \mathrm{Cl}$ to the nitrogen-free media falled to indicate the presence of $\mathrm{NO}_{3}^{-}$. Furthermore, no $\mathrm{NO}_{3}^{-}$was detectable in water extracts of plants grown at any level of $\mathrm{NH}_{4}-\mathrm{N}$ (Fig. 6). If plants in the $\mathrm{NH}_{4}-\mathrm{N}$ solutions were utilizing $\mathrm{NO}_{3}^{-}$produced by nitrification, $\mathrm{NO}_{3}^{-}$should appear in water extracts of dried plants as considerable $\mathrm{NO}_{3}^{-}$occurs In tissues of plants grown in even the lowest level of $\mathrm{NO}_{3}-\mathrm{N}$.

When compared to plants grown in the $\mathrm{NO}_{3}-\mathrm{N}$ media, those cultured in $\mathrm{NH}_{4}-\mathrm{N}$ contained a greater percentage nitrogen at the same solution nitrogen level (Fig. 6). Percentage nitrogen was affected by both forms of nitrogen added $(P<0.05)$ and level of nitrogen $(P<0.01)$. There was no interaction of the two factors $(P>0.05)$. At the same leve1 of nitrogen, less inorganic nitrogen was extracted from tissues of plants grown on $\mathrm{NH}_{4}-\mathrm{N}$ than from plants grown on $\mathrm{NO}_{3}-\mathrm{N}$ (Fig. 6). It appears that once in the plant, $\mathrm{NH}_{4}^{+}$is more rapidly incorporated into organic nitrogen compounds than is $\mathrm{NO}_{3}-\mathrm{N}$.

Although the nitrogen available at the highest level was eight times greater than that at the lowest level, there was only a twofold difference in the nitrogen content of plants grown in those two 


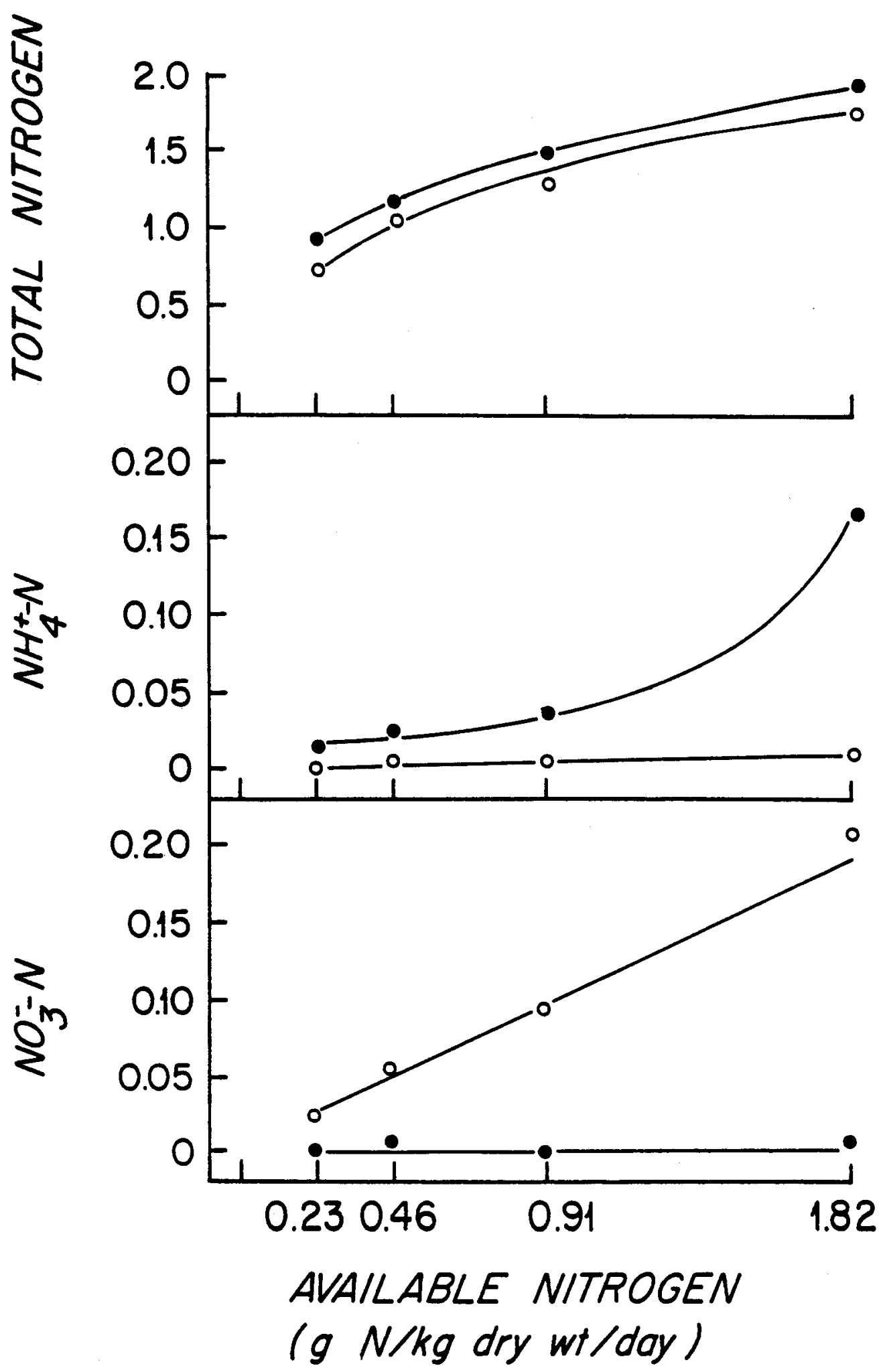

Figure 6. Total nitrogen, nitrate, and ammoniun content of water hyacinths cultured on four levels of nitrogen avallability. Nitrogen was supplied as either anmonium (closed circles) or nitrate (open circles). Values are as $\%$ of dry weight). 
solutions. This phenomenon has been noted in certain terrestrial forages (Russe11, 1973). The extra dry matter production stimulated by the added nitrogen tends to "dilute" the nitrogen taken up by the plant. The amount of nitrogen taken up per unit area per day more closely reflects nitrogen availability. Using average yield and nitrogen content for plants grown on $\mathrm{NH}_{4}-\mathrm{N}$, an average of 0.10 $\mathrm{gN} / \mathrm{m}^{2} /$ day was taken up by plants at the lowest level of nitrogen. At the highest level $0.70 \mathrm{gN} / \mathrm{m}^{2} /$ day was taken up by the plants. The sevenfold difference in nitrogen accrual on an aerial basis reflects the difference in nitrogen availability within limits of experimental error.

It has generall.y been noted that water hyacinths grown in fertile environments contain significantly more ash than plants grown under less fertile conditlons (M. D. Hanisak, Harbor Branch Foundation, personal communication). In the present study only nitrogen level was varied and concentrations of other nutrients remained constant in all treatments. Ash content decreased as $\mathrm{NH}_{4}-\mathrm{N}$ availability increased and remained essentially unchanged as $\mathrm{NO}_{3}-\mathrm{N}$ levels increased (Table 4). This may be due to the same "dilution" factor discussed above in relation to nitrogen content. Furthermore, $\mathrm{NH}_{4}^{+}$al so decreases uptake of other cations, particularly calcium (Beeson, 1946), and this may be one factor contributing to the decrease in ash content as $\mathrm{NH}_{4}-\mathrm{N}$ levels increase. With increasing nitrogen availability 
Table 4. Ash content of water hyacinths grown at four levels of available nitrogen. Nitrogen was supplied as either ammonium or nitrate.

\begin{tabular}{ccc}
\hline $\begin{array}{c}\text { Avaflable nitrogen } \\
(\mathrm{g} \mathrm{N} / \mathrm{kg} \text { dry wt/day) }\end{array}$ & \multicolumn{2}{c}{ Ash of dry wt $)$} \\
& $\mathrm{NH}_{4}-\mathrm{N}$ grown & $\mathrm{NO}_{3}-\mathrm{N}$ grown \\
\hline 0.23 & $16.3 \mathrm{a}^{1}$ & $16.8 \mathrm{a}$ \\
0.46 & $15.5 \mathrm{a}$ & $17.2 \mathrm{a}$ \\
0.91 & $14.3 \mathrm{ab}$ & $17.7 \mathrm{a}$ \\
1.82 & $12.8 \mathrm{~b}$ & $17.6 \mathrm{a}$ \\
\hline
\end{tabular}

${ }^{1}$ Values designated by different letters were determined to be significantly different at the 0.05 level of probability by Duncan's New Multiple Range Test (vertical comparisons only). 
Lotal accrual of minerals on an aerial basis obviously increased as yield increased considerably and percentage ash changed little.

A11 carbohydrate fractions measured were affected by nitrogen availability. The percentage nonstructural carbohydrates (Fig. 7) in water hyacinths decreased as nitrogen level increased $(P<0.05)$. Amount of nonstructural carbohydrate was not affected by the form of nitrogen added ( $P>0.05)$ and there was no interaction of the two factors $(P>0.05)$.

Percentage structural carbohydrates also varied as nitrogen availability changed, with water hyacinths becoming increasingly fibrous as nitrogen levels decreased. Both lignocellulose and cellwall fraction were affected by availability of nitrogen ( $P<0.01$ ). Neither fiber values were affected by form of nitrogen ( $P>0.05)$ nor was there any interaction of level and form of nitrogen ( $P>0.05)$. Van Soest and coworkers developed the system of plant fiber analysis based on solubility in solutions of detergent (Van Soest, 1966). Plant matter insoluble in acid detergent consists of relatively pure lignocellulose and results have been found to give a satisfactory estimate of digestibility by ruminant animals (Van Soest, 1963). The neutral detergent technique separates plant material into cel1-wal1 and noncel1-wa11 fractions (Van Soest and Wine, 1967). Digestibility of plant material by nonruminant consumers is correlated with noncel1wall fraction. The difference between neutral and acid detergent fiber gives a crude estimate of the hemicellulose content of the plant 


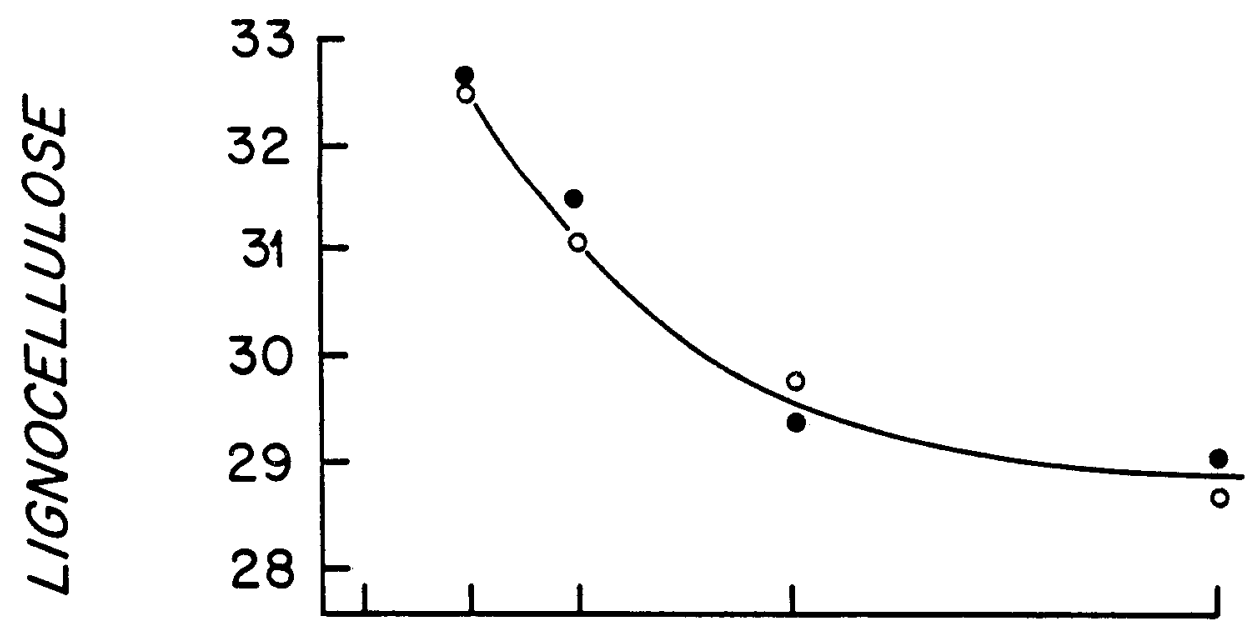

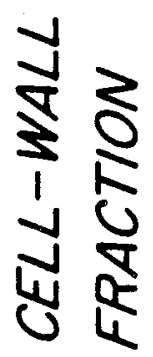

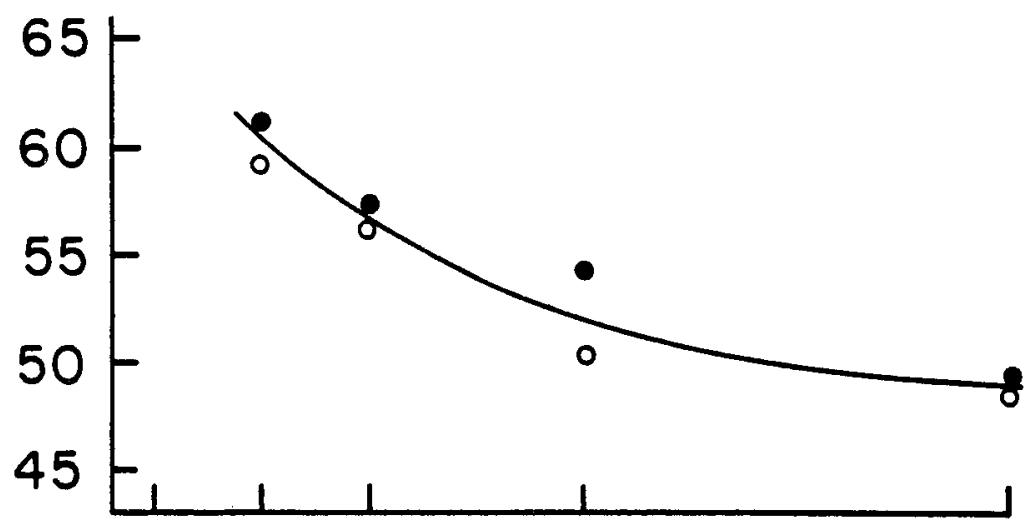

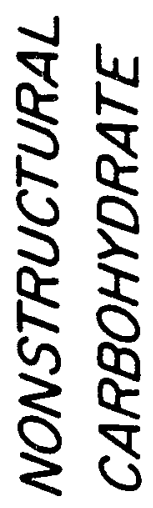

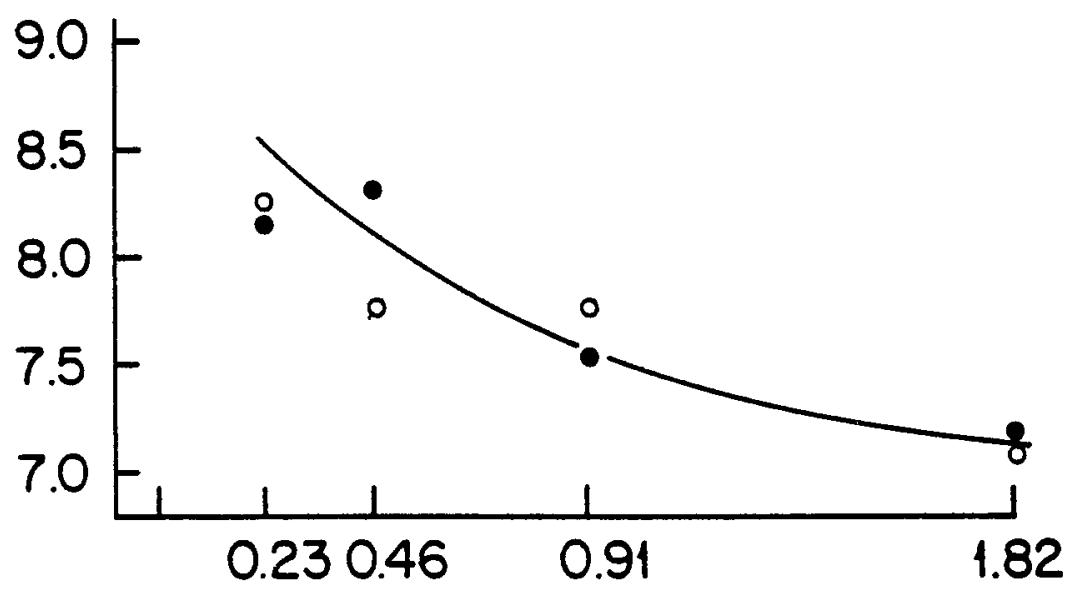

AVAILABLE NITROGEN

(g N/kg dry wt/day)

Figure 7. Lignocellulose, cell-wall fraction, and nonstructural carbohydrate content of water hyacinths cultured on four levels of nitrogen availability. Nitrogen was supplied as either ammonium (closed circles) or nitrate (open circles). Values are as $\%$ of dry weight. 
As stand density increases and growth is restricted predominantly to a vertical direction, the need for supportive tissue arises. Data in Table 5 demonstrate the trend for increased cell-wall material as density increases. The increase in cell-wall material is accounted for by the increase in lignocellulose, as the percentage of hemicelluloses (ce11-wall fraction minus lignocellulose) remained fairly constant. The other carbohydrate fraction, the nonstructural carbohydrates, showed no definite trend as density changes.

Ce11-wa11 material, as measured by the neutral detergent technique, consists primarily of hemicelluloses, cellulose, and low-nitrogen lignins (Van Soest, 1966). The decrease in percentage nitrogen as these low-nitrogen compounds increase is not surprising. Similarly ash content decreases with increasing stand density.

Blogas production during anaerobic decomposition of water hyacinths of differing nutritional quality.

Water hyacinths were obtained from two sites during May, 1979. One batch, collected from a natural stand located near Okeechobee, Florida, was growing under nutrient deficient-high stand density conditions. These w111 be designated "low" quality. The other plants were obtained from a culture growing at the aquaculture facility at the Harbor Branch Foundation. These water hyacinths were growing at a maintained density of $10 \mathrm{~kg}$ wet $\mathrm{wt} / \mathrm{m}^{2}$ in the nutrient solution given in Table 3 . These will be designated "high" quality. Several plants from each batch were analyzed as described earlier. These results are presented in Table 6. 
material (Van Soest, 1966). Polisini and Boyd (1972) recognized the value of these methods in estimating non-nutritive residues of aquatic plants. Boyd and Goodyear (1971) suggest crude protein and neutral detergent solubility as two important indicators of the nutritive quality of plant material

The trends in levels of structural and nonstructural carbohydrates of water hyacinth as nitrogen availability varies are similar to those in terrestrial forages (Russell, 1973; Tisdale and Nelson, 1975). Increased nftrogen supplies not only increase the yield of water hyacinths but also produces plants of greater nutritive value. As nitrogen availability increases, synthesized carbonhydrates are more rapidly converted to proteins and less carbohydrate is available for deposition as cell-wall material. The consequence is plants with a higher proteln content and a lower percentage of non-nutritive residue which should increase digestibility and nutritive value for both ruminant and nonruminant consumers.

Density study:

Morphological characteristics of water hyacinths grown under the same conditions but at different densities are presented elsewhere in this report (Chapter 5, Table 3). One of the more obvious trends is the increase in plant height or stem length as plant density increases. The presence in nature of two growth forms of hyacinth has been noted earlier and appears to be a plant density-related phenomenon. 
Table 5. Partial breakdown of the composition of water hyacinths cultured at three stand densities. Each value is the average of two samples from separate culture vaults. All values are as $\%$ of dry weight.

\begin{tabular}{lccc}
\hline Component & \multicolumn{3}{c}{$\begin{array}{c}\text { Density } \\
\text { (kg wet weight/m }\end{array}$} \\
& 5 & 10 & 20 \\
\hline Total nitrogen & 3.8 & 3.9 & 3.2 \\
Cell-wall material & 38.1 & 42.2 & 46.5 \\
Lignocellulose & 22.7 & 24.3 & 29.8 \\
Hemicelluloses & 15.4 & 17.9 & 16.7 \\
$\begin{array}{l}\text { Nonstructural } \\
\text { carbohydrate }\end{array}$ & 6.5 & 7.0 & 5.8 \\
Ash & 19.3 & 18.4 & 16.7 \\
\hline
\end{tabular}


Table 6. Partial composition of water hyactnths used in biogas production study.

\begin{tabular}{lcc}
\hline Component & \multicolumn{2}{c}{ Water hyacinth batch } \\
& "low" quality & 2.98 \\
\hline "high" quality \\
L1gnocellulose (\% dry wt) & 0.98 & 25.6 \\
Ash (\% dry wt) & 34.7 & 19.3 \\
Dry matter (\% wet wt) & 17.0 & 4.9 \\
\hline
\end{tabular}


Approximately $4 \mathrm{~kg}$ of plants from each batch were ground in a garden shredder. The ground plant material was added to 41 digesters at rates indicated in Table 7. A total of four digesters were used, two each for both "low" and "high" quality water hyacinths. An inoculum of $50 \mathrm{ml}$ of liquid effluent from an established methane-producing digester was added to each 41 digester. Blogas production was determined daily as described elsewhere (Chapter 6).

The results of the 30 -day trial are presented in Fig. 8. Obviously there is a considerable difference in both rate and volume of biogas produced during the 30 -day operational period. Although results show only biogas production, gas from a11 four digesters sustained a flame when samples taken at day 15 were ignited indicating methane production. Further studies will be conducted to examine the relative importance of nitrogen content and fibrous material and their role in bringing about the differences in digestibility. 
Table 7. Amount of water hyacinth loaded into 4-1 anaerobic digesters.

\begin{tabular}{lcc}
\hline Weight basis & \multicolumn{2}{c}{$\begin{array}{c}\text { Amount added (g) } \\
\text { "high" quality }\end{array}$} \\
\hline Wet weight & 1500 & 1900 \\
Dry weight & 93 & 93 \\
Volatile solids & 77.2 & 75.3 \\
\hline
\end{tabular}




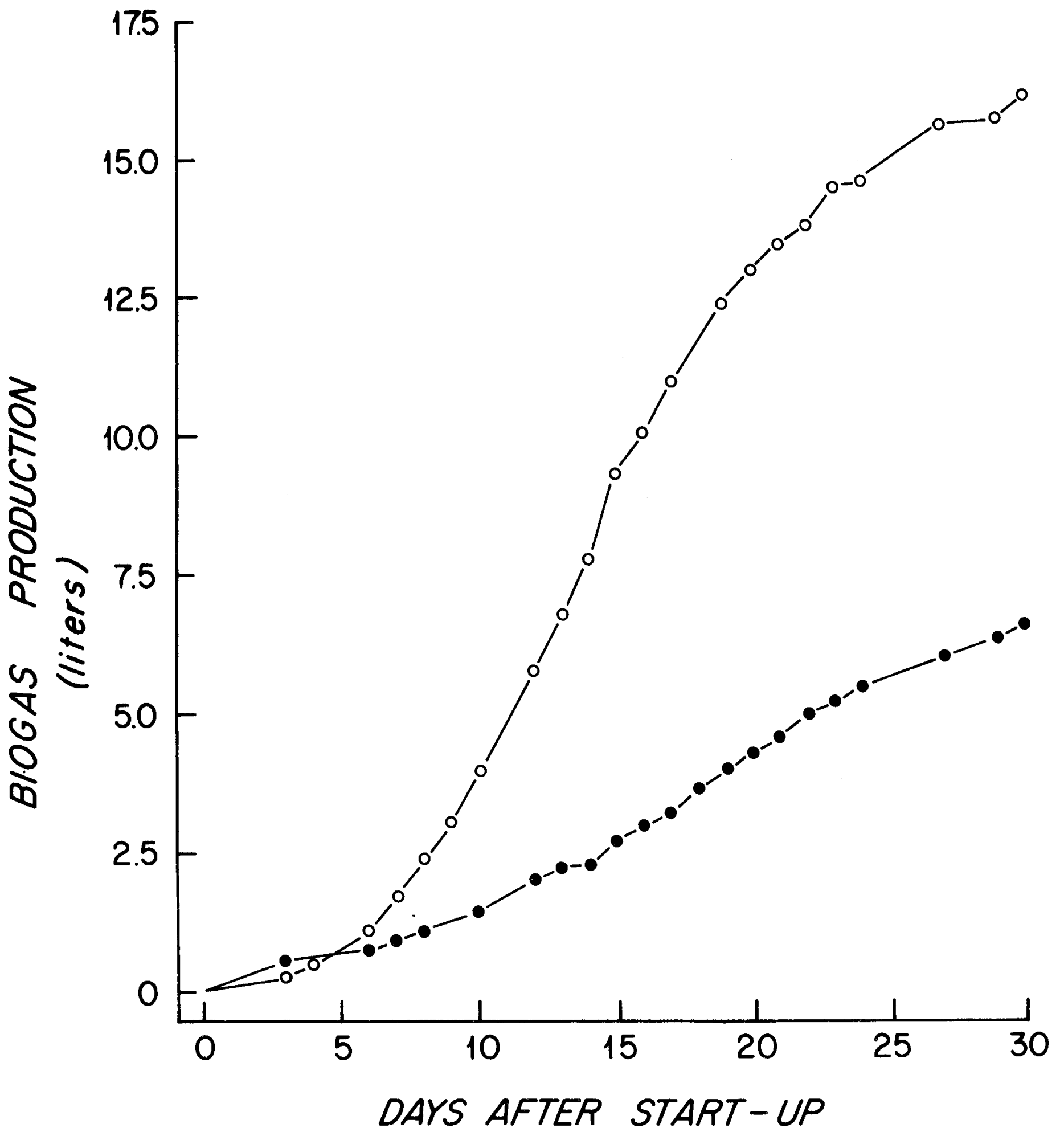

Figure 8. Cumulative biogas production from anaerobic decomposition of "low' (closed circles) and "high" (open circles) quality water hyacinth: Each point is the average of gas produced from two digesters.

81 
Summary :

Preliminary work at this facility indicated a considerable difference in biogas production during anaerobic decomposition of water hyacinths of differing nutritional quality. Low nitrogenhigh fiber plants produced considerably less gas within a 30-day period than high nitrogen-1ow fiber plants. Work is continuing to determine the relative importance of nitrogen and the various cell-wal1 components in bringing about this difference in digestibility. However, results of studies on the factors affecting the composition of water hyacinth indicated that nitrogen and fiber vary together inversely. Therefore a range of quality is to be found with high fiber-low nitrogen plants at one end and low fiber-high nitrogen plants at the other.

Under conditions of constant density and nutrient availability, highest quality plants are produced in the cooler months in central Florida. This is fortuitous as the increased biogas production when these higher quality plants are digested should partially offset the decreased plant yield also occurring at this time. Ignoring the effect of season, highest quality plants are the result of culture in waters and moderate to high nitrogen availability (0.91-1.82 $\mathrm{g}$ $\mathrm{N} / \mathrm{kg}$ dry wt/day) and at low to moderate density $\left(5-10 \mathrm{~kg}\right.$ wet $\left.\mathrm{wt} / \mathrm{m}^{2}\right)$. The effect of density on composition must be weighed against its effect on yield. Although highest quality plants are produced at lowest densities, DeBusk et al. (in press) showed that $20 \mathrm{~kg}$ wet wt/ $\mathrm{m}^{2}$ was near optimum for maximum water hyacinth dry matter productivity. 
References:

Alexander, M. 1961. Introduction to Soil Microbiology. John Wiley and Sons, New York, N.Y. 473 pp.

American Public Health Association. 1971. Standard Methods for the Examination of Water and Wastewater. Am. Pub1ic Health Assoc., New York, N.Y. 874 pp.

Beeson, K. C. 1946. The effect of mineral supply on the mineral concentration and nutritional quality of plants. Bot. Rev. 12: 424-455.

Boyd, C. E. 1969a. The nutritive value of three species of water weeds. Econ. Bot. 23: 123-127.

Boyd, C. E. 1969b. Production mineral nutrient absorption, and biochemical assimilation by Justicia americana and Alternanthera

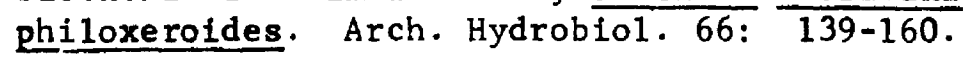

Boyd, C. E. 1970. Production, mineral accumulation, and pigment concentrations in Typhe latifolia and Scirpus americanus. Ecology 51: 285-290.

Boyd, C. E. 1976. Accumulation of dry matter, nitrogen and phosphorous by cultivated water hyacinths. Econ. Bot. 30: 51-56.

Boyd, C. E. and R. D. Blackburn. 1970. Seasonal changes in the proximate composition of some common aquatic weeds. Hyacinth Cont. Jour. 8: $42-44$.

Boyd, C. E. and C. P Goodyear. 1971. Nutritive quality of food in ecological systems. Arch. Hydrobio1. 69: 256-270.

Boyd, C. E. and D. H. Vickers. 1971. Variation in the elemental content of Eichhornia crassipes. Hydrobiologia 38: 409-414.

DeBusk, T. A., M. D. Hanisak, L. D. Williams and J. H. Ryther. 1979. Primary production of some freshwater macrophytes. Aquatic Bot. In press.

Heinze, P. H. and A. E. Murneek. 1940. Comparative accuracy and efficiency in determination of carbohydrates in plant material. Missouri Agric. Exp. Sta. Bu1l. 314.

Knipling, E. G., S. H. West and W. T. Haller. 1970. Growth characteristics, yield potential, and nutritive content of water hyacinths. Proc.

Soll and Crop Sci. Soc. Florida 30: 51-63. 
Larsen, B. and A. Jensen. 1957. The determination and nitrate and nitrite in algal material, and the seasonal variations in the nitrate content of some Norwegian seaweeds. Norwegian Institute of Seaweed Research Report No. 15. 22pp.

Musil, C. F. and C. M. Breen. 1977a. The influence of site and position in the plant community on the nutrient distribution in, and content of Eichhornia crassipes (Mart.) Solms. Hydrobiologia 53: $67-72$.

Musil, C. F. and C. M. Breen. 1977b. The application of growth kinetics to the control of Elchhornia crassipes (Mart.) Solms through nutrient removal by mechanical harvesting. Hydroblologia 53: $165-171$.

Nichols, D. S. and D. R. Keeney. 1976. Nitrogen nutrition of Myriophyllum spicatum:variation of plant tissue nitrogen concentration with season and site in Lake Wingra. Fresh. Biol. 6: 137-144.

Penfound, W. T. and T. T. Earle. 1948. The biology of the water hyacinth. Eco1. Monogr. 18: 447-472.

Polisini, J. M. and C. E. Boyd. 1972. Relationships between ce11wall fractions, nitrogen and standing crop in aquatic macrophytes. Ecology 53: 484-488.

Russell, E. W. 1973. Soil Conditions and Plant Growth. Longman Group, Ltd. T.ondon. $848 \mathrm{pp}$.

Smith, D., G. M. Paulson and C. A. Raguse. 1964. Extraction of total avatlable carbohydrates from grass and legume tissue. Plant Physio1. 39: 960-962.

Strickland, J.D.H. and T. R. Parsons. 1972. A Practical Handbook of Seawater Analysis. Fisheries Research Board of Canada, Ottawa. 310 pp.

Tisdale, S. L. and W. L. Nelson. 1975. Soil Fertility and Fertilizers. Macmillan, Inc. New York, N.Y. 694 pp.

Van Soest, P. J. 1963. Use of detergents in the analysis of fibrous feeds. II. A rapid method for the determination of fiber and lignin. Jour. Ass. Offic. Agr. Chem. 46: 829-835. 
Van Soest, P. .T. 1965. Use of detergents in the analysis of fibrous feeds. III. Study of effects of heating and drying on yield of fiber and lignin in forages. Jour. Ass. Offic. Agr. Chem. 48: 785-790.

Van Soest, P. J. 1966. Non nutritive residues: a system of analysis for the replacement of crude fiber. Jour. Ass. Offic. Agr. Chem. 49: 546-551.

Van Soest, P. J. and R. H. Wine. 1967. Use of detergents in the analysis of fibrous feeds. IV. Determination of plant cel1-wall constituents. Jour. Ass. Offic. Agr. Chem. 50: 50-55. 
V. Growth and yield of aquatic plants

by

John H. Ryther

Farmers and ecologists are familiar with the concept of plant productivity or yield - the amount of material produced per unit of area and time. Short-term yields are usually expressed as $\mathrm{g} / \mathrm{m}^{2}$.day, seasonal or annual crops as metric tons/hectare.year (or the more familiar, to many, British units of short tons/acre.year, which are 0.36 times the metric units). Ecologists interested in the comparative productivity of different kinds of plant species or communities usually express yields in dry weight, often in ash-free dry welght, which is to say the strictly organic fraction of the plant production.

Other botanists concerned with physiological processes of organisms think in terms of the specific growth rate of plants. This may be expressed as $g$ increase/g.day or, more often, \% increase/day or doubling time in days.

Growth and yield are, of course, closely related, yleld being the product of growth rate and plant density. But the relationship is not constant because growth rate is itself a variable function of density. This is illustrated for four quite different kinds of aquatic plants in Fig. 1. Original data were obtained for the marine diatoms, from Goldman and Ryther (1), for the red seaweed Gracilaria, from Ryther et a1. (2), and for the two freshwater macrophytes, from DeBusk et al. (3).

The diatoms were grown in Woods Hole, MA in 20001 (2.3 m diameter $0.5 \mathrm{~m}$ deep) continuous cultures of seawater enriched with $2^{\circ}$ treated 

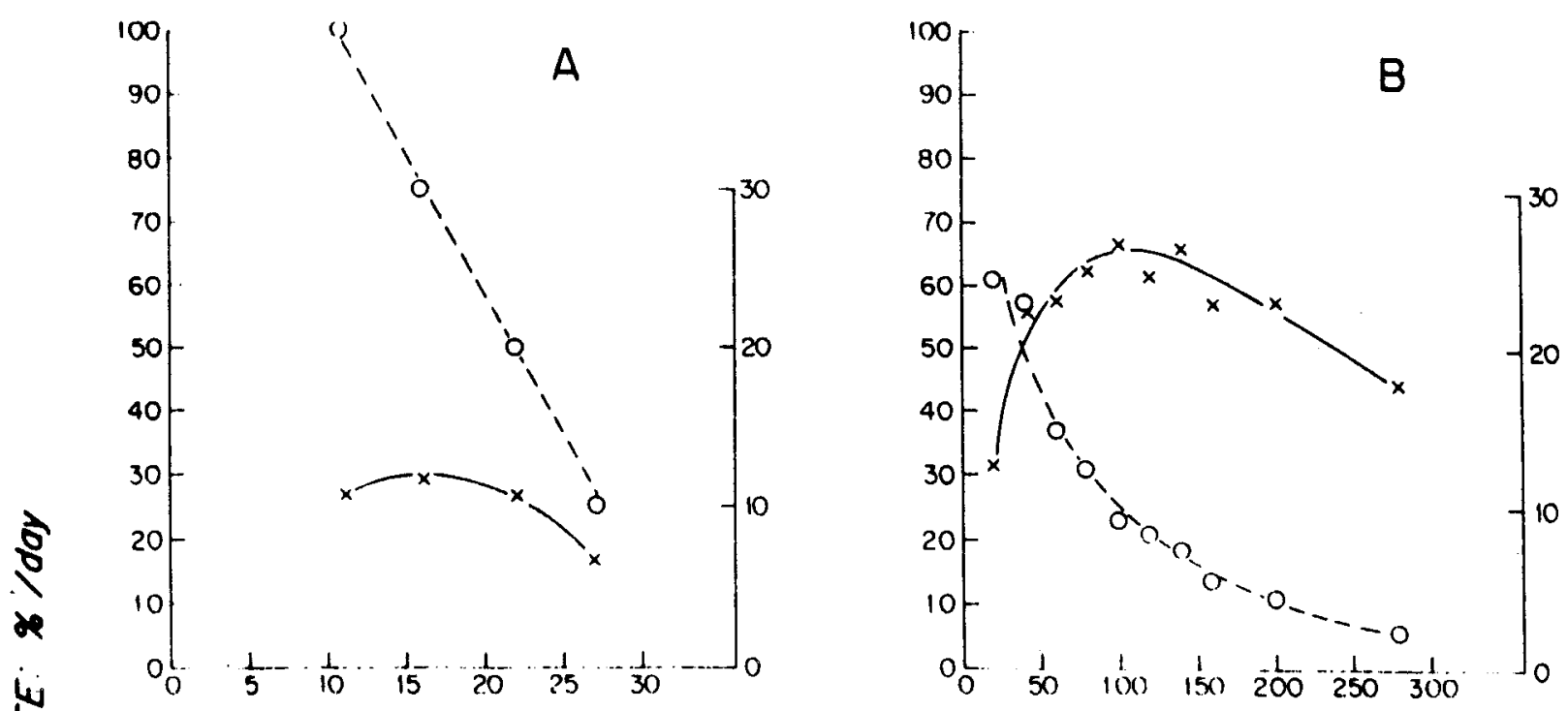

ถั
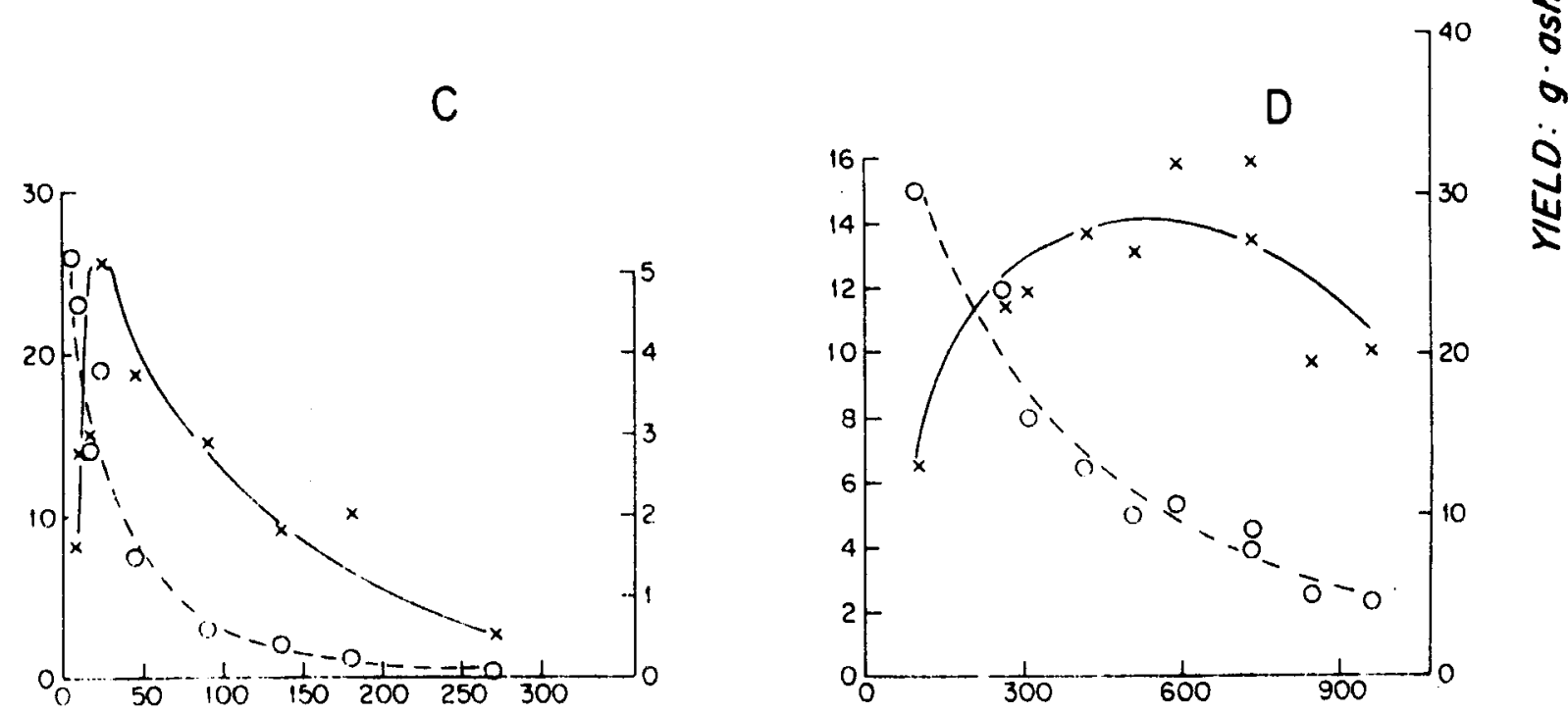

PLANT OENSITY: $g \cdot$ ash-free dry wt. $/ \mathrm{m}^{2}$

Flgure 1. Growth rate (broken line) and yleld (solid line) of marine diatoms (A), the red seaweed Gracllaria tikvahiae (B), and the freshwater macrophytes, ducksweed (Lemna minor) (C), and water hyacinth (EIchhornia crassipes (D) as a function of plant density. Note that both horizontal and vertical scales differ for the respective spectes. 
sewage effluent. In steady state, growth rate was considered equivalent to dilution rate, density was measured as particulate organic carbon and doubled to give total ash-free dry weight, and yield calculated as the product of density and dilution rate. The diatoms were essentially monocultures of Phaeodactylum tricornutum, Amphipora sp., and Amphora sp. which succeeded each other as dominants during the course of the experiment.

The Gracilaria was grown in Fort Pierce, FL in 50 I outdoor cultures in which the plants were suspended by aeration and through which enriched seawater was circulated at an exchange rate of 20 volumes/day. The culture was removed from the water, drained and weighed at weekly intervals. Ash-free dry weight was considered at $5.0 \%$ of wet weight. Density is expressed as the mean of the starting and final weight for each one week interval.

The freshwater macrophytes duckweed (Lemna minor) and water hyacinth (Eichhornia crassipes) were also grown in Fort Pierce, F1 in $25,0001\left(30 \mathrm{~m}^{2}\right.$ area, $0.5 \mathrm{~m}$ deep) PVC-lined earthen ponds through which enriched well water was exchanged at one volume/day.

The water hyacinths were held in Vexar-mesh cages ranging in size from one to $2.3 \mathrm{~m}^{2}$. At intervals of one week the cages with the contained plants were lifted from the water, allowed to drain, and weighed. Duckweed was grown loose in the pond. Each week, the plants were netted from the water, drained and weighed. Ash-free dry weights of Lemna and Elchhornia were considered to be $9.0 \%$ and $4.25 \%$ of wet weight respectively. 
Yields of the three macrophytes are expressed as the mean daily increase in ash-free dry weight/m ${ }^{2}$ for each weekly interval and mean growth rate for that interval obtalned by dividing yield by mean density.

A11 of the above studies were carried out over a period of four to six months during late spring, summer and early fall. Growth rates and ylelds were at or near their annual maxima and are not typical or representative of average conditions throughout the year. However, the relationships between the three variables appear, on the basis of preliminary evidence, to be the same in winter as in summer.

In every case, growth rate decreased with increasing plant density. Yleld, the product of the two, was greatest at an intermediate density. The reason for the decline in growth rate is not clear, but is probably assoeiated with effects of overcrowding-self-shading, nutrient limitation, accumulation of metabolites, etc. If so, there is presumably a density below which no interaction between individual plants and no change in gorwth rate occurs, but that threshold was not observed in the experiments reported here. One can say only that the phenomenon appears to be a general characteristic of aquatic plants, possibly of all plants. The photosynthetic portions of both duckweed and water hyacinth are, after all, air-borne the same as terrestrial plants. Watson (4) obtained a very similar relationship between the yfeld of kale and its leaf-area index, a unit that is proportional to total plant density. Optimal yield was obtained at an intermediate leaf-area index above and below which it declined rapidly. Davidson 
and Donald (5) described a similar relationship in clover, and Kasanaga and Monsei (6) developed a numerical mode1 to predict optimal leafarea index for maximum plant production.

The relationship described above is of considerable importance in the context of current research programs investigating the potential of plant biomass as a source of energy. The most sensitive factor in assessing the economic or energy cost-effectiveness of such biomass systems is that of organic yield. In that connection, growth rate is often confused with yield. Duckweeds, for example, have, due to their "phenomenal reproduction rate" been credited as being "more productive than terrestrial agricultural crops" (7) and able to "grow at least twice as fast as other higher plants" (8). But it may be seen in Fig. IC that the highest growth rate of duckweed occurs at a very low density and that actual yields of the species are relatively low when compared to the better agricultural crops, grasslands, and forests (e.g., 9).

The yields of food and fiber crops may be determined simply by welghing the seasonal or annual harvest. No such expedient is possible with plant populations that are not commercially grown and utilized. In order to assess the potential yield of such species there is no substitute to cultivating them throughout the year or growing season in either natural or experimental plots and harvesting and weighing the resulting crop. For species in mild climates that are able to grow continuously in a vegetative mode, such as all four of the 
examples shown in Fig. 1, it is necessary to harvest the new growth frequently enough to maintain the density of plants at or near its optimum for maximum yield, if the full potential of the species for blomass production is to be determined.

Such experiments are difficult and time consuming and tend to be replaced by simpler but more crude yleld estimates. One such approach has been to measure the growth rate of a given species experimentally, in the field or laboratory, and to apply such growth rates to a measured or estimated density of natural stand of the plants to obtain annual yield values. In some cases short-term growth rates have been used to calculate annual ylelds, thereby Ignoring seasonal effects. This general approach has been used to estimate the annual production of several kinds of aquatic plants Including rockweeds and kelps in Nova Scotia (10), giant kelp off California (11), seagrasses (12), and water hyacinths (13). Reference to Fig. 1 clearly shows how the use of independent values of dafly growth rate and density and extrapolation of the resulting dafly to annual yields may result in greatly exaggerated projections. Using the maximum growth rates and densities for the seaweed Gracllaria and the freshwater Eichhornia as given in Fig. $1 \mathrm{~B}$ and $1 \mathrm{D}$, for example, would result in annual yield estimates in excess of 500 ash-free dry tons/ha.yr. Actual measured ylelds of sma1l, experimental cultures of the two species maintained under the best possible conditions throughout the year in Central Florida were respectively 63 and 75 ash-free dry tons/ha.yr $(2,3)$. 
To put these figures in perspective, the best commercial yields of sugar cane, the world's most productive agricultural crop, are rough1y 63 ash-free tons/ha.yr (14). Commercial seaweed production ranges from about one ash-free ton/ha.yr from the harvest of natural beds of glant kelp off California to some 25 ash-free tons/ha.yr for the small kelp, Laminaria japonica, that is cultivated in Northern China (15)

Thus Wolverton and McDonald's estimate (13) of 154 dry tons (ca. 131 ash-free dry tons) of water hyacinths/ha. for a seven-month growIng season in Mississippi, obtained from separate measurements of growth rate and density, must be considered as suspect. Also untenable is the projection, similarly obtained, of up to 262 ash-free dry tons of giant kelp/ha.yr from the ocean energy farm that is presently in the pilot-testing phase by General Electric Corp., under contract from the Gas Research Institute and the Department of Energy (16).

Such lavish estimates have tended to create an unrealistic opinion of the potential role of aquatic plants as a biomass source for energy. This could prove unfortunate, since many aquatic species are, in fact, comparable to the most productive terrestrial crops in their organic yields and do not need exaggerated projections to justify their consideration 
References and Notes

1. J. C. Goldman and J. H. Ryther, J. Environ. Eng. Div., ASCE 101, 351 (1975). The same relationship has been demonstrated for these and other data concerning unicellular algae by J. C. Goldman, Water Res. 13, 1 (1979)

2. J. H. Ryther, J. A. DeBoer, B. E. Lapointe, Proc. 9th Internat. Seaweed Symp. 9, 1 (1978).

3. T. A. DeBusk, M. D. Hanisak, L. D. Williams, J. H. Ryther, Aquatic Botany, In press.

4. D. J. Watson, Ann. Bot. N.S. 22, 37 (1958).

5. J. L. Davidson, C. M. Donald, Aust. J. Agr. Res. 9, 53 (1958).

6. H. Kasanaga, M. Monsi, Jap. J. Bot. 14, 304 (1954).

7. Nat. Acad. Sci. Rep. Ad Hoc Panel of Adv. Comm. on Tech. Innov. "Making aquatic weeds usefu1", 175 pp. (1976).

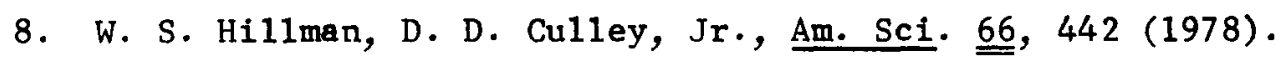

9. D. 0. Hall, FEBS Letters 64, 6 (1976).

10. K. H. Mann, Mar. Biol. 14, 199 (1972).

11. K. A. Clendenning, Nova Hed. 32 (Supp1.), 259 (1971).

12. A. Thorhaug, M. A. Roessler, Aquaculture 12, 253 (1977).

13. B. C. Wolverton, R. C. McDonald, NASA-ERL Rept. No. 171 (1978).

14. E. S. Lipinsky, T. A. McClure, R. A. Nathan, T. L. Anderson, W. J. Sheppard, W. T. Lawhon, Battelle Columbus Lab. Task 77 Final Rep. BMI-1957 (Vo1. 2) (1976). Ash-free dry weight of sugar cane is considered equivalent to the sum of "fermentable solids" and combustable organics", which is equal to $80 \%$ of "total dry matter". 
15. J. H. Ryther, Oceanus $\underline{2}$, 21, (1979). Seaweed harvest statistics are given as total dry weight, of which ash-free dry weight is considered to be roughly half.

16. Testimony of Dr. Ab Flowers, Director, Gas Supply Research, Gas.

Res. Inst. before Subcomittee on Oceanogr., Comm. on Merchant

Mar. and Fish., U.S. House Rep., Sept. 26, 1979. 
VI. Evapotranspiration of some emergent freshwater plants by

Thomas A. DeBusk

One of the possible constraints to the use of freshwater plants for biomass production is the potential loss of freshwater, already In critically short supply in many parts of the country, through evaporation or, in the case of emergent species, evapotranspiration. The latter has been reported as being as much as 3-4 times the water loss from evaporation alone (i.e., from water surfaces where no plants are present) in such spectes, for example, as water hyacinths (Eichhornia crassipes) (e.g., Penfound and Earle, 1948; Timmer and Weldon, 1967; Holm et a1., 1969). However, many of the earlier studies had not been performed out-of-doors under natural conditions, where the plants would be exposed to the prevailing meteorological and climatic conditions. One study in which the plants were studied under natural conditions showed that evapotranspiration of water hyacinths was only 1.26 times evaporation alone (Brezny et a1., 1973). Because that study was done in India, where the climate may have been quite different from Southern United States, and because the results of the Indian study were rather different from those reported for the same species in the United States, additional research on the subject was carried out at the Harbor Branch Foundation, Fort Pierce, Florida over a nine-month period in 1979.

Water hyacinth (E1chhornia crassipes), duckweed (Lemna minor), and pennywort (Hydrocotyle umbellata) were grown in 4001 polyethy1ene cylindrical tanks (Fig. 1). At intervals of one to two weeks, the 


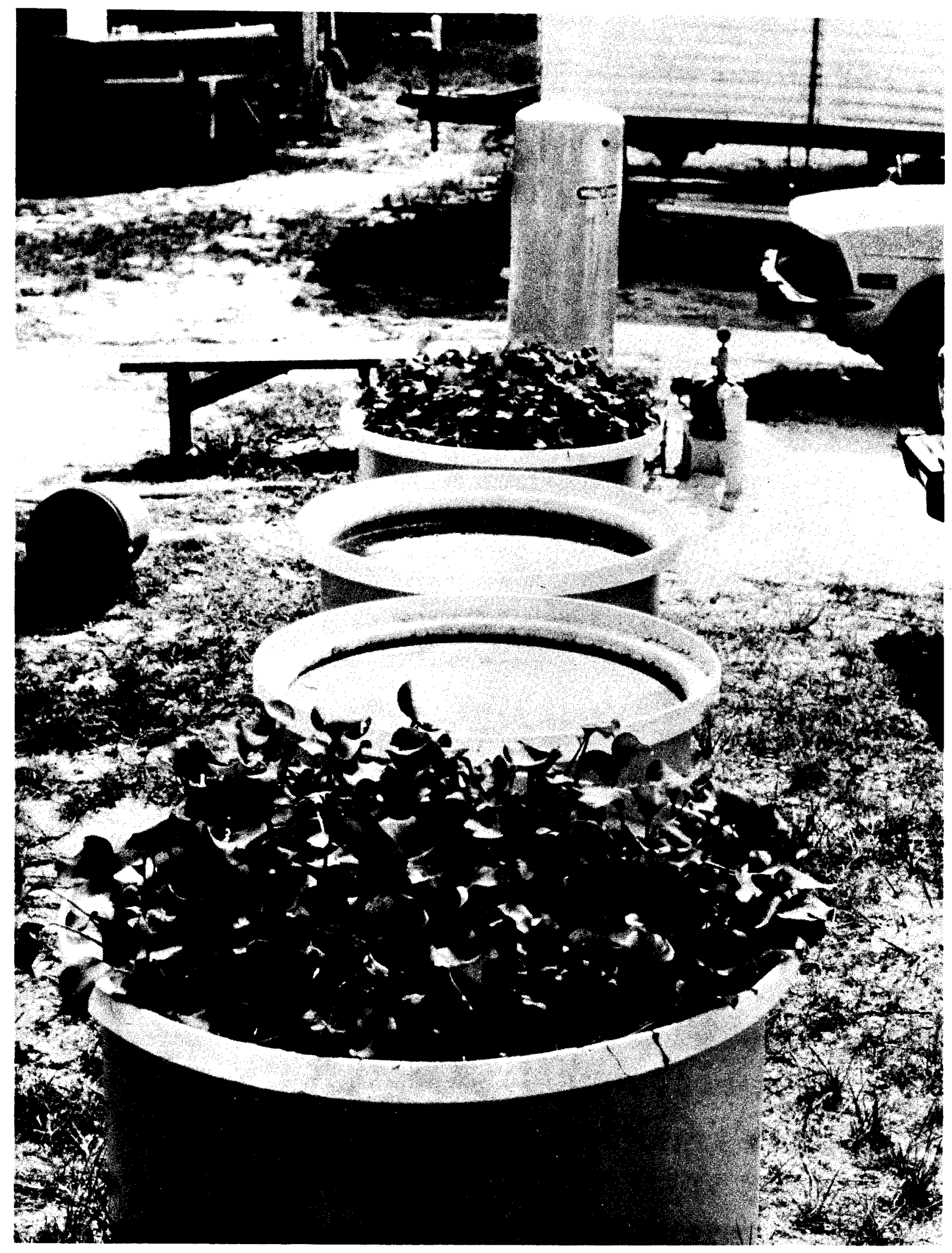

Figure 1. Cylindrical tanks used for measurement of evapotranspiration rates of freshwater macrophytes. 
plants were removed from the contalners, drained, and weighed. New growth since the last weighing was harvested, returning the plants to a constant initial density of 400,25 , and $800 \mathrm{~g}$ ash-free dry $w t / m^{2}$ for the hyacinths, duckweed and pennywort respectively. At that time, the water in the tanks was replenished with a measured volume, considered equivalent to evapotranspiration minus the water content of the harvested plants. The refilled containers were then enriched with $1500 \mu$ moles/1 $\mathrm{NO}_{3}-\mathrm{N}, 150 \mu$ moles/l $\mathrm{PO}_{4}-\mathrm{P}$, and a commercial mixture of trace metals and chelated iron ${ }^{*}$. A fourth tank containing only freshwater was used as a control to monitor evaporation alone.

The studies reported here were carried out from January 17September 26, 1979, and are presently being continued to complete a full year of observation. Studies with pennywort were not started until March 27, 1979. Accompanying these experiments, solar radiation has been monitored with an Epply 50-junction pyroheliometer mounted at the plant culture facility at the Harbor Branch Foundation. Average daily air temperature (from readings every four hours), wind speed (from hourly readings) and relative humidity (from twice daily readings) were compiled from data collected at Vero Beach Municipal Airport, located approximately 12 miles from the laboratory. Those

\footnotetext{
*Sunniland "Nutri-spray", Chase Chemical Co., Sanford, FL and Vigoro "Liquid Iron", Swift Agricultural Chemical Corp., Chicago, IL.
} 
daily averages were then averaged again over the one-two week intervals over which the plant growth and water loss was monitored.

In separate studies with just water hyacinths, water loss was monftored in four cultures in which the plants were maintained at four different densities of $200,400,800$ and $1200 \mathrm{~g}$ ash-free dry weight $/ \mathrm{m}^{2}$ respectively.

The mean dally meteorological data, plant yields and water losses from evaporation and evapotranspiration are all shown in Fig. 2. The cumulative water losses from the water surface and from the three plant cultures are shown in Fig. 3. From the latter, mean daily water losses and the ratio of evapotranspiration to evaporation alone $(E T / E)$ for the three spectes were calculated over the duration of the experiment. These data, presented in Table 1, as we11 as an inspection of Fig. 3, show that evapotranspiration in water hyacinths is 1.7 times that of evaporation from a bare water surface alone, in rather close agreement with the value of 1.3 reported by Brezny et al. (1973). The value of ET/E of 0.9 for duckweed indicates that a cover of that plant serves as a method of water conservation, as had earlier been reported by Seybold (1930). Pennywort is the most extravagant user of water of the three species tested, losing almost as much in 132 days as did water hyacinth in 209 days (see Fig. 3) and averaging a ET/E value of 2.0 . 


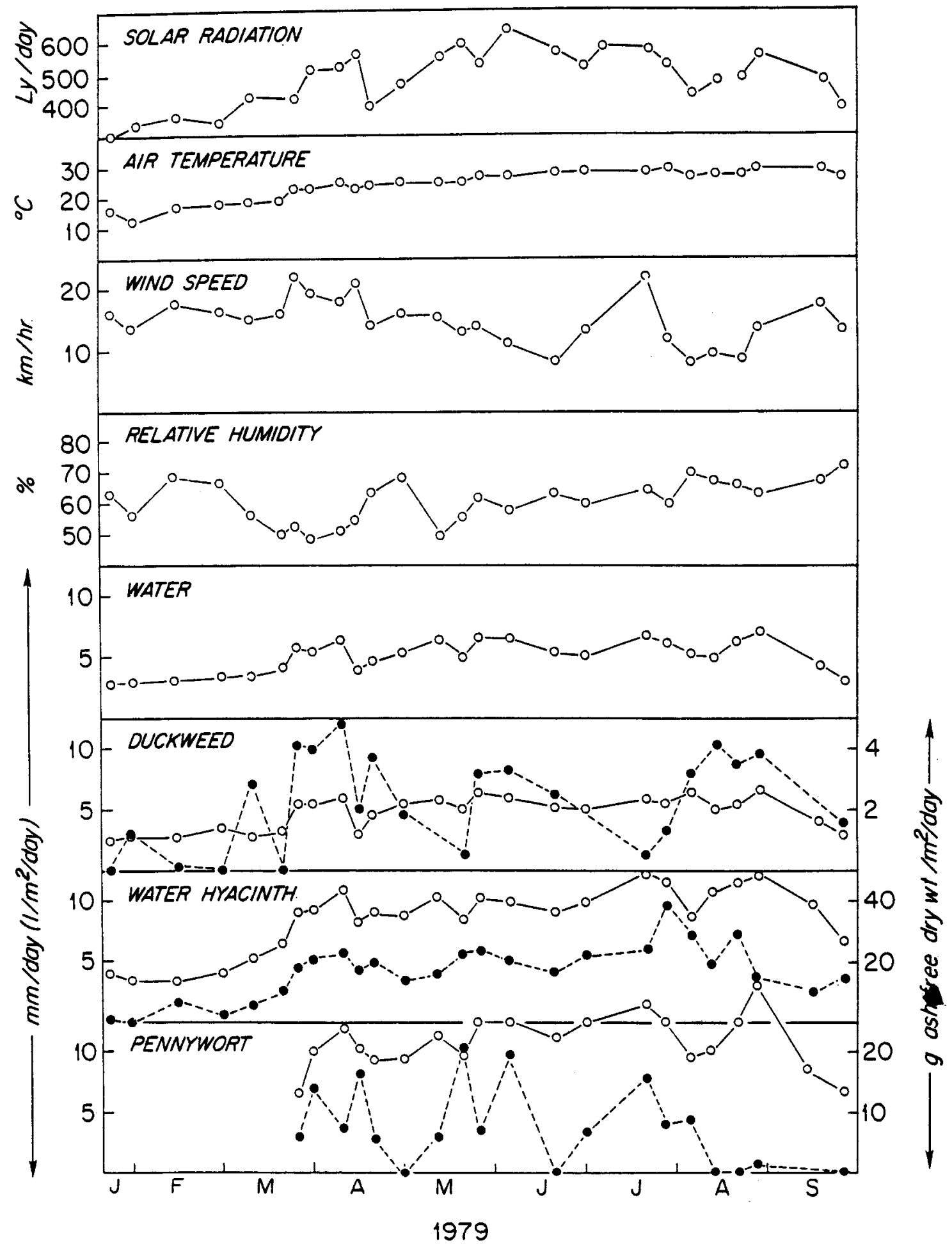

Figure 2. Evapotranspiration rates (open circles) and yields (closed circles) of freshwater macrophytes, evaporation rate from bare water surface, and related environmental factors. 


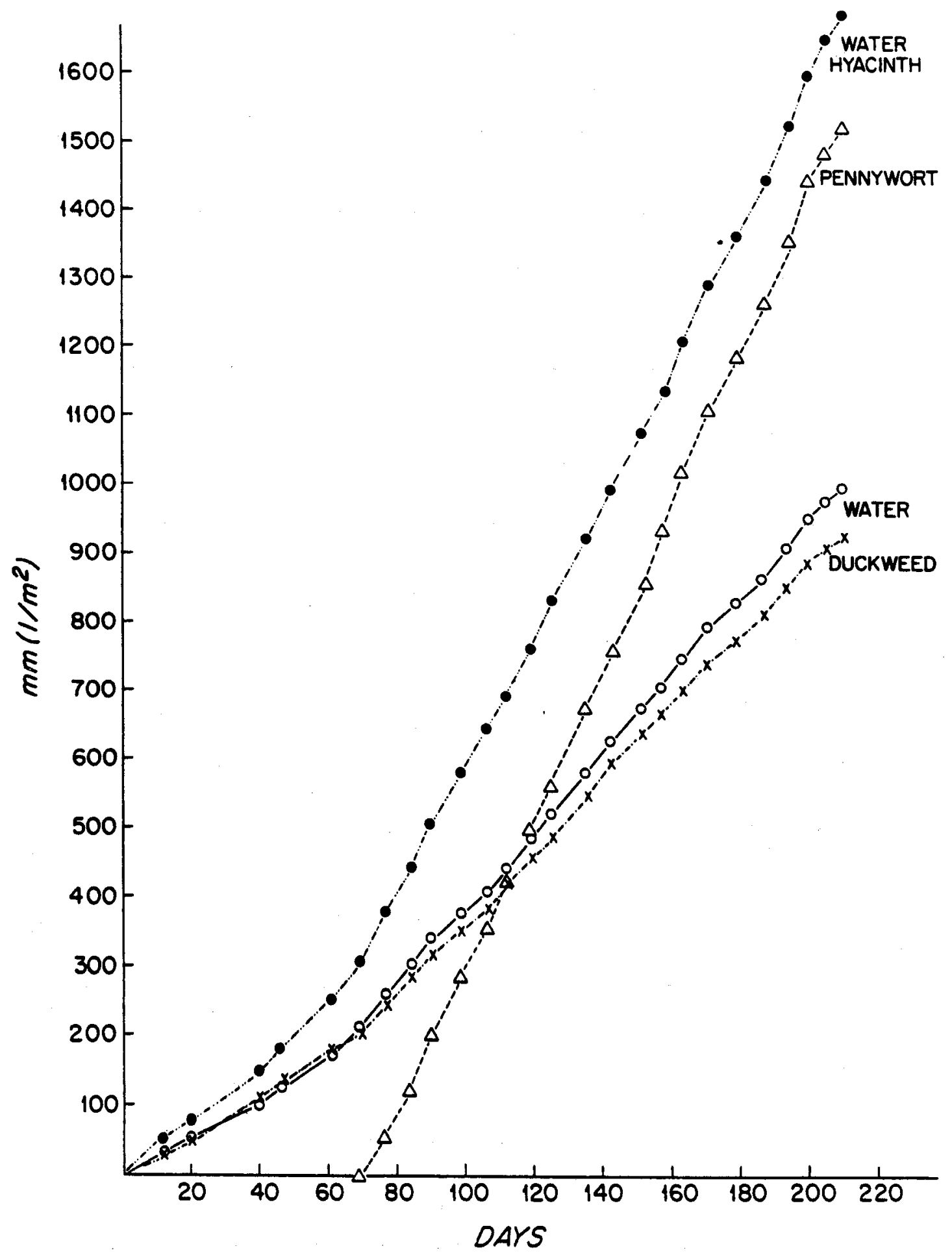

Figure 3. Cumulative water loss from freshwater macrophyte cultures and bare water surface from January 17 through September 26, 1979. 
I'ahle 1. Nverage water loss in $\mathrm{mm} / \mathrm{day}$ or $1 \mathrm{iters} / \mathrm{m}^{2}$.day and the ratio of evapotranspiration: open water evaporation ( ${ }^{\mathrm{ITT}} / \mathrm{E}$ ) for duckweed and water hyacinth from 1/17-9/26/79, and for pennywort from $3 / 27$ to $9 / 26 / 79$.

\begin{tabular}{lcc}
\hline & $\begin{array}{c}\text { Mean water loss } \\
\left(\mathrm{mm} / \text { day or } 1 / \mathrm{m}^{2} \text {.day) }\right.\end{array}$ & ET $/ \mathrm{E}$ \\
\hline Control (water) & 4.7 & \\
Duckweed & 4.4 & 0.9 \\
Water hyacinth & 8.0 & 1.7 \\
Pennywort & 10.8 & 2.0 \\
\hline
\end{tabular}


In the above experiments, water loss from evaporation or evapotranspiration is reported as mm/day, as appears to be conventional in such studies. For the interest of those concerned with absolute water loss, one mm surface reduction is equivalent to a volume loss of one 1 iter $/ \mathrm{m}^{2}$ of surface (as also indicated on the tables and graphs) or approximately one thousand gallons/acre. Thus, the cumulative water $10 \mathrm{ss}$ from water hyacinths shown in Fig. 3, if extrapolated to a year, would result in an annual loss of about three million gallons of freshwater per acre, of which about 1.2 million ( $41 \%$ ) is in excess of the amount that would be lost from open water alone.

An attempt was made, by simple linear regression analyses, to determine which of the factors monitored were chiefly responsible for the evapotranspiration losses by the three plant species (Table 2). As would be expected, water loss from all three plant species was highly correlated with incident solar radiation. For both water hyacinth and duckweed, loss is also highly correlated with air temperature and yield, but the meaningfulness of the latter is questionable since yleld is also strongly influenced by solar radiation and temperature. Only pennywort, which appears to grow Irregularly with a rhythm characterized by pulses followed by omplete cessation of growth (see Fig. 2) falled to show a correlation between water loss and yield. 
Table 2. Simple linear correlations between evapotranspiration by three aquatic plants and air temperature, solar radiation, wind speed and relative humfdity. A1so correlations between evapotransplration and ash free dry weight yields of the three species.

No.

r

$t$

A. Air temperature

$\begin{array}{llll}\text { duckweed } & 26 & 0.72 & 5.10^{1} \\ \text { water hyacinth } & 26 & 0.88 & 9.16^{1} \\ \text { pennywort } & 20 & 0.45 & 2.14^{2}\end{array}$

B. Solar radiation

$\begin{array}{llcc}\text { duckweed } & 26 & 0.92 & 11.54^{1} \\ \text { water hyacinth } & 26 & 0.83 & 7.29^{1} \\ \text { pennywort } & 20 & 0.61 & 3.27^{1}\end{array}$

C. Wind speed

duckweed

water hyacinth

D. Relative humidity

duckweed
water hyacinth
pennywort

E. Yield

$$
\begin{aligned}
& \text { duckweed } \\
& \text { water hyacinth } \\
& \text { pennywort }
\end{aligned}
$$

23

26

19
0.58

0.79

0.07
3. $28^{1}$

$6.33^{1}$

$0.29^{3}$

1 Significant at $1 \%$ level.

${ }^{2}$ Significant at $5 \%$ level.

${ }^{3}$ Not significant. 
An inverse relationship existed between water loss and both wind speed and relative humidity. There was less wind in summer when evapotranspiration was greatest for reasons mentioned above, and evaporation is inversely proportional to humidity. However, the correlation with those two environmental factors was not significant.

Since density of the plants was held constant, as closely as possible, by routine harvesting of the cultures back to the same inftial stocking density, the effects of that factor on evapotranspiration could not be evaluated in the studies thus far reported. For that reason a special study was made of the effect of density of water hyacinths on their water loss, with an attempt to separate the effects of density per se from those of the growth and yield of the plants. As indicated in Table 3, the greater the density of the plants ( $1 . e .$, expressed as ash-free dry weight per unit of water surface area), the greater the amount of leaf and stem foliage area that is exposed to the air and to evapotranspiration losses, expressing such areas in the units conventionally used in plant physiology. As may be seen in Table 4, the greater the density of water hyacinths, the greater the ${ }^{E T} / E$ ratio, which nearly doubled (from 1.35 to 2.27) with an increase in density from 200 to $800 \mathrm{~g} \mathrm{afdw} / \mathrm{m}^{2}$. However, yield also doubled with the same increase in density, so it is not clear whether the increase in $E T / E$ was caused by more plant surface or more metabolic activity, or both. Further studies will be made of the effect of water hyacinth density on the rate of evapotranspiration during the remainder of the year. 
Table 3. Morphological characteristics of water hyacinths cultivated at four different densities (in $g$ ash-free dry $w t / \mathrm{m}^{2}$ ).

\begin{tabular}{|c|c|c|c|c|c|}
\hline Density & $\begin{array}{c}\text { Leaf area } \\
\text { Index }{ }^{1}\end{array}$ & $\begin{array}{c}\text { Stem area } \\
\text { Index }\end{array}$ & $\begin{array}{l}\text { Mean No. } \\
\text { Stems } / \mathrm{m}^{2}\end{array}$ & $\begin{array}{l}\text { Mean leaf } \\
\text { Size }\left(\mathrm{cm}^{2}\right)\end{array}$ & $\begin{array}{l}\text { Mean stem } \\
\text { Length }(\mathrm{cm})\end{array}$ \\
\hline 200 & 3.4 & 4.0 & 631 & 54.5 & 21.1 \\
\hline 400 & 4.8 & 6.3 & 559 & 86.4 & 28.4 \\
\hline 800 & 6.0 & 11.3 & 655 & 91.0 & 42.7 \\
\hline 1200 & 7.8 & 13.7 & 817 & 95.2 & 42.0 \\
\hline
\end{tabular}

${ }^{1}$ Area of leaf surface/area water surface.

${ }^{2}$ Area of stem surface/area water surface. 
Table 4. Mean ash-free dry weight yields $\left(\mathrm{g} / \mathrm{m}^{2}\right.$.day) and evapotranspiration: open water evaporation ratios $(E T / E)$ of water hyacinths grown at four different densities ( $g$ ash-free dry $w t / m^{2}$.

\begin{tabular}{ccc}
\hline Density & Yield $^{1}$ & ET/E \\
\hline 200 & $14.6 \mathrm{a}$ & $1.35 \mathrm{a}$ \\
400 & $24.7 \mathrm{a}, \mathrm{b}$ & $1.76 \mathrm{~b}$ \\
800 & $32.5 \mathrm{~b}$ & $2.27 \mathrm{c}$ \\
1200 & $26.8 \mathrm{~b}$ & $2.10 \mathrm{c}$ \\
\hline
\end{tabular}

${ }^{1}$ Values in each column followed by the same letter do not differ significantly at the $5 \%$ level as determined by Duncan's New Multiple Range Test. Each value is the mean of four trials. 
References

Brezny, 0., I. Mehta and R. M. Sharma. 1973. Studies on evapotranspiration of some aquatic weeds. Weed Sci. 21: 197-204.

Ho1m, L. G., L. W. We1don and R. D. B1ackburn. 1969. Aquatic Weeds. Sci. 166: 699-709.

Otis, C. H. 1914. The transpiration of emersed water plants: its measurement and its relationships. Bot. Gaz. 58: 457-494.

Penfound, W. T. and T. T. Earle. 1948. The biology of the water hyacinth. Eco1. Monogr. 18: 448-472.

Seybold, A. 1930. Die pflangliche transpiration. I. $\mu$. II. Frgeb. Bio1. 5:29 (quoted in Brezny et a1., 1973, but not read by the present authors).

Timmer, C. E. and L. W. Weldon. 1967. Evapotranspiration and po1lution of water hyacinth. Hyacinth Control J. 6: 34-37. 
VII. Recycling digester residues as a source of nutrients for the growth of water hyacinths (Elchhornia crassipes).

$$
\text { by }
$$

M. Dennis Hanisak and L. D. Williams

Several digesters (Fig. 1) with overall dimensions of $45 \mathrm{~cm} \mathrm{x}$ $45 \mathrm{~cm} \times 80 \mathrm{~cm}$ (total volume $=1621$ ), were constructed from $0.5 \mathrm{~cm}$ sheet plastic. Their lids were made from $0.3 \mathrm{~cm}$ thick sheet polyvinyl chloride (PVC) reinforced with $1.3 \mathrm{~cm}$ plywood and bolted to the digester after being sealed alrtight with weatherstripping caulk. Loading and discharge ports were made of $10 \mathrm{~cm}$ PVC pipe with screwcap ends and two smaller $(2.5 \mathrm{~cm})$ PVC pipes with valves were provided for removal of 1 iquid residue. Due to the location of the loading and discharge ports, the functional volume (that which actually contained digesting materia1) was about 1201 for each digester. One side of each digester contained a Plexiglass window for visual observation of the digester's contents. Gas lines led from the tops of the digester to inverted, submerged 2081 stee1 drum manometers where the gas was collected and its volume measured.

The water hyacinths that were digested had been grown in ponds containing nutrient-enriched water (1). In order to facilitate handling of the plant material and loading of the digesters, the water hyacinths were shredded (Sears Roebuck Electric Yard and Garden Shredder), producing a greenish-black slurry that had the consistency and texture of wet mud when wet and of peat moss when dry. The plants were chopped immediately after harvest and removal from the 


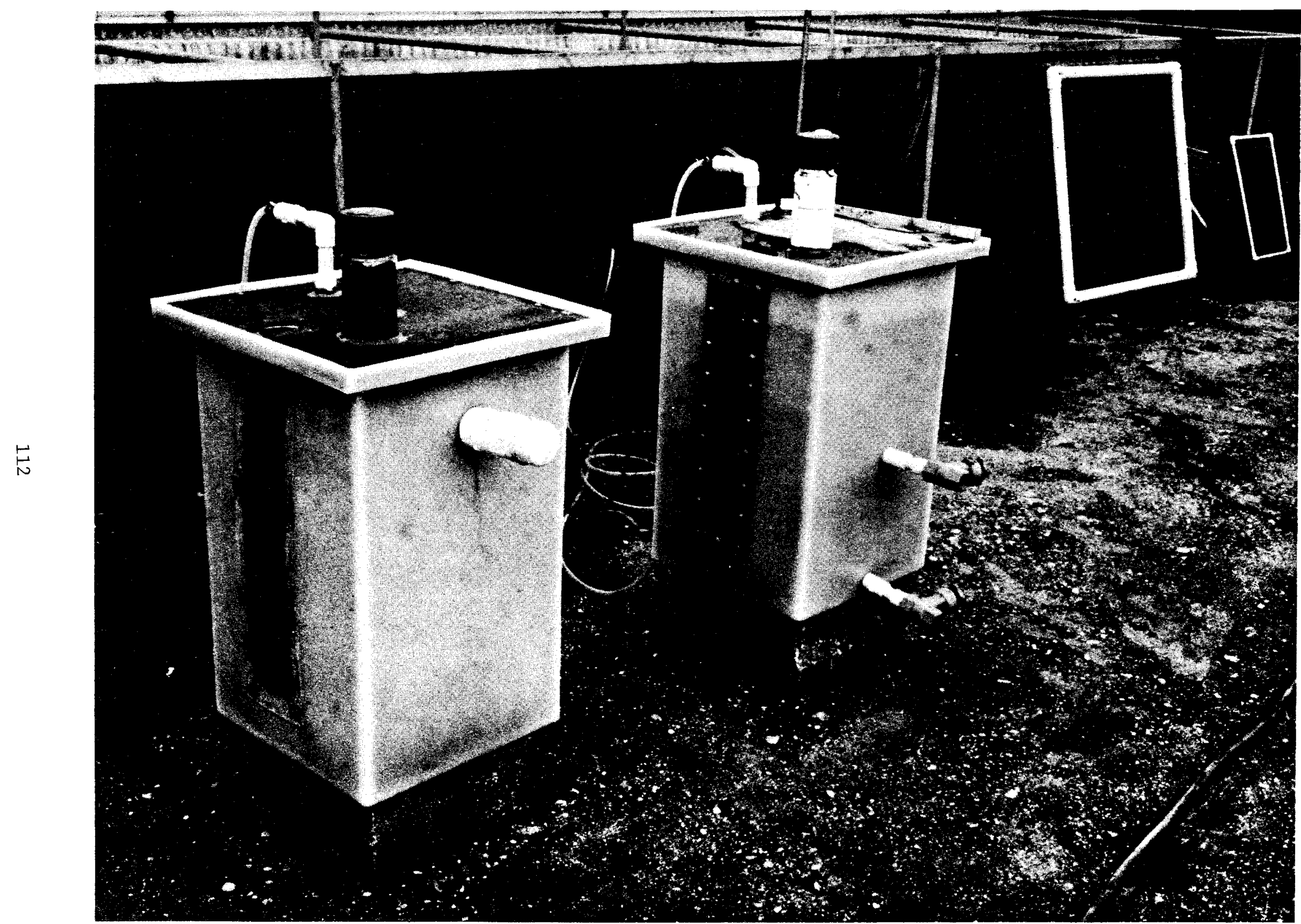

Figure 1. Anaerobic digesters used for fermenting water hyacinths. 
water. Even partial drying rendered the plant material tough, fibrous, and resistent to shredding; soaking in water did not reconstitute the plant material to a suitable form for shredding.

Digestion of water hyacinths could be initiated by two methods. In the first, fermenting dairy manure was used as an inoculum and was gradually replaced with water hyacinths. Shredded water hyacinths were added three times a week at a loading rate equivalent to 1.10 to $1.38 \mathrm{~g}$ volatile solids/1 digester volume/day (residence time of 30-38 days). Alternatively, water hyacinths could be digested in a "batch" mode in which $100 \mathrm{~kg}$ wet weight of water hyacinths were loaded into a digester. No pretreatment of the biomass was required for fermentation to occur. Gas production began in about 30 days. After the initiation of gas production, the digester could be loaded on a routine basis or continued in a batch mode without any further addition of biomass until gas production ceased (in 90-120 days). The start-up time for batch digesters could be decreased by adding $20 \%$ liquid effluent from another water hyacinth digester to the initial inoculum. The observations in this communication refer specifically to two digesters that were loaded on a regular basis for more than one year (April, 1978-May, 1979).

These two digesters were loaded 1-3 times a week with a loading rate equivalent to $0.74 \mathrm{~g}$ volatile solids/1/day (15 $\mathrm{kg}$ wet weight of shredded water hyacinths) and a mean residence time of eight 
weeks. Gas production was not affected by changinghe loading regimen from three smaller loads a week to one larg' weekly load. Each time the digesters were loaded, an equivalent lume of liquid residue was removed from the digester. The content of the digester were not stirred, and the solid fraction floated athe surface above the liquid fraction. To prevent the solids fm plugging the discharge port, a screen was inserted below theischarge port in order to trap the solids.

The digesters were kept at ambient temperature $30^{\circ} \mathrm{C} \pm 5^{\circ} \mathrm{C}$ ) during most of the year. During the cooler months, the year (November-March), the digesters were kept partiallyubmerged in a 38001 circular water tank which was kept at apprimately $30^{\circ} \mathrm{C}$ by an immersion heater.

To investigate the suitability of the digesteresidue as a nutrient source for growing water hyacinths, three tch cultures of this species, maintained at a density of $10 \mathrm{~kg} w$ weight $/ \mathrm{m}^{2}$, were grown in Vexar plastic mesh cages $\left(1.2 \mathrm{~m}^{2}\right.$ ) thathad been placed in concrete tanks ( $2.20 \times 0.80 \times 0.45 \mathrm{~m}$ and $1.70 \mathrm{~m}^{2} \mathrm{n}$ water area) containing approximately 7501 of water (Fig. 2). ( these three cultures, the first was grown on unenriched well war, the second on water enriched with a nutrient medium normally ud to grow water hyacinths (Table 1), and the third received liquid gester residue. Tnitially 51 of this effluent was added three timea week, but this was changed to 101 (during the winter when grth was reduced) 


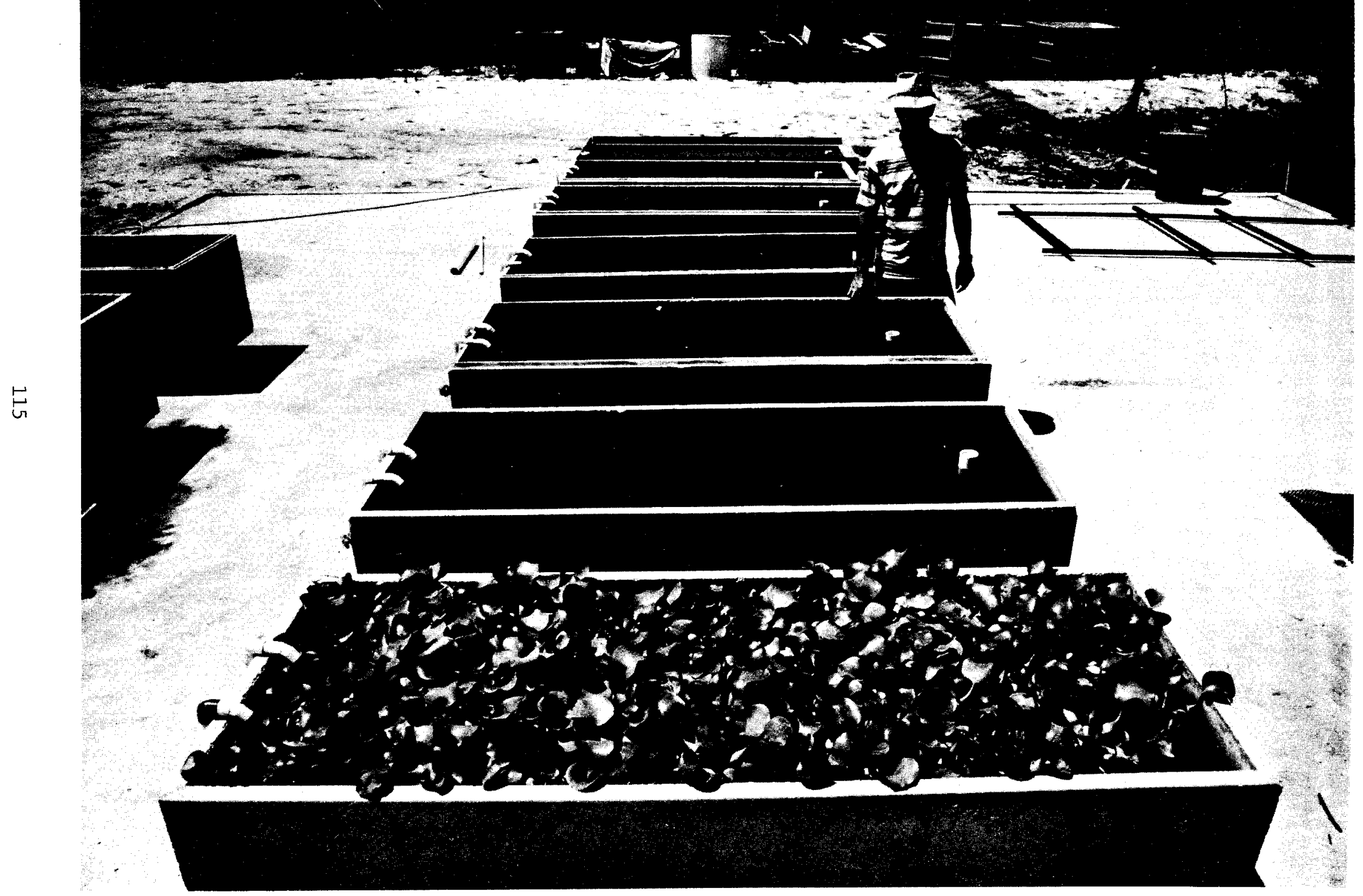

Figure 2. Concrete vaults containing culture of water hyacinths in foreground. 
Table 1. Final composition of enrichment medium used for growing water hyacinths.

\begin{tabular}{cl}
$\mathrm{NaNO}_{3}$ & $76.6 \mathrm{mg} / 1$ \\
$\mathrm{KNO}_{3}$ & 60.8 \\
$\mathrm{CaCl}_{2} \cdot{ }^{2 \mathrm{H}_{2}{ }^{0}}$ & 55.5 \\
$\mathrm{Na}_{2}{ }^{\mathrm{HPO}}{ }_{4} \cdot \mathrm{H}_{2}{ }^{0}$ & 24.0 \\
$\mathrm{MgSO}_{4} \cdot 7 \mathrm{H}_{2}{ }^{0}$ & 23.8 \\
$\mathrm{Trace} \mathrm{meta1}^{\mathrm{mix}}$ & \\
$\mathrm{Fe}$ & 2.0 \\
$\mathrm{~S}$ & 1.5 \\
$\mathrm{Mn}$ & 0.75 \\
$\mathrm{Zn}$ & 0.75 \\
$\mathrm{Cu}$ & 0.10 \\
$\mathrm{~B}$ & 0.02 \\
$\mathrm{Mo}$ & 0.01 \\
\hline
\end{tabular}

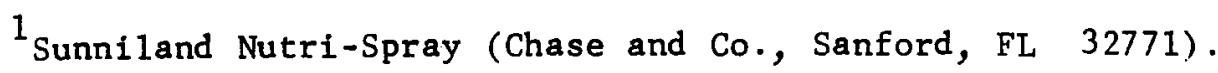


or 151 (after growth increased from its winter minfmum) added weekly at the same time that the digesters were loaded. The recycling of the liquid residue began four months after the start-up of the digesters (a time period believed to be more than ample for steady state to have been achieved).

After a month, the artifically enriched culture became chlorotic and unhealthy in appearance and these plants were sprayed weekly with additional trace elements (Nutri-spray, Table 1) which restored them to a norma1 appearance. It was subsequently found that this spraying was not necessary if chelated iron was added to the water. The water in the first two cultures was changed weekly; the unenriched culture grew slowly for 15 weeks and was subsequently terminated. The water in the culture grown in liquid effluent was not exchanged nor did the plants receive the trace element spray or any other form of enrichment than the liquid digester residue. Approximately every three months, the digesters were opened and the solid residue (i.e., sludge) that floated on the surface was removed and weighed. Studies were initiated to recycle the nutrients contained in this solid residue in a fashion similar to that described for the liquid residue, with the exception being that it was added only once evf ry four weeks (12 kg sludge/four weeks). Growth of the water hyacinths was determined by weekly lifting the Vexar baskets containing the cultures out of the tanks, draining them for four minutes, and weighing them with a spring 
scale. Incremental growth was removed from the cultures and the cultures were returned to their tanks. Productivity was expressed as mean daily yield of dry weight $/ \mathrm{m}^{2}$ for each weekly interval assuming a dry weight equivalent to $5 \%$ of the wet weight. These methods of messuring primary productivity are discussed more completely elsewhere (1).

Levels of nitrate, nitrite, ammonium, phosphate and total nitrogen were monitored (2) in the tanks prior to and after the additions of digester residues. The nitrogen and carbon contents of plants or solid residue were determined with a Perkin-E1mer Model 240 Elemental Analyzer. The amount of organic matter (1.e., volatile solids) of plants or solid residue was determined after ashing dried samples (dried at $60^{\circ} \mathrm{C}$ for $48 \mathrm{hrs}$ ) for four hours at $550^{\circ} \mathrm{C}$ in a muffle furnace.

Stable, continuous anaerobic digestion of water hyacinths was maintained for longer than a year, with an average gas production of $0.41 / \mathrm{g}$ volatile solids, at $60 \%$ methane (Table 2). The heat of combustion of water hyacinths was determined by Boyd (3) to be approximately $3.8 \mathrm{kcal} / \mathrm{g}$ dry weight which would be equal to $4.6 \mathrm{kcal} / \mathrm{g}$ ash-free dry weight (since water hyacinths were on average $18 \%$ ash) or $19 \mathrm{~kJ} / \mathrm{g}$ volatile solids. Since pure methane has an energy content of approximately $37 \mathrm{~kJ} / 1$, the above methane production represents an average bioconversion efficiency of about $47 \%$. 
Tahle 2. Characteristics of stable, continuous anaerobic digestion of water hyacinths.

$\begin{array}{ll}\begin{array}{l}\text { Temperature } \\ \text { Agitation }\end{array} & 30^{\circ} \mathrm{C} \pm 5{ }^{\circ} \mathrm{C} \\ \text { Load composition } & \begin{array}{l}\text { none } \\ \text { chopped water hyacinths at } 5 \% \\ \text { volatile solids }\end{array} \\ \text { Mean loading rate } & \begin{array}{l}0.73 \mathrm{~g} \text { volatile solids } / 1 \\ \text { digester/day }\end{array} \\ \text { Mean residence time } & 56 \text { days } \\ \text { Normal pH range } & 6.8-7.3 \\ \text { Gas production } & 0.41 / \mathrm{g} \text { volatile solids, at } \\ \end{array}$


Both the liquid and the solid digester residues were a good source of nutrients for the growth of water hyacinths (Table 3). Cultures grown on these residues were consistently more productive than that which was chemically enriched, with an average productivity of $65 \%$ and $47 \%$ higher over the entire period for the liquid residue and the solid residue respectively. The yields of the chemically enriched culture and that of the liquid residue were two and three times higher, respectively than that of the unenriched control. All of these differences were determined to be statistically highly significant $(P<0.01)$ by the Student's t test using paired observations. The growth of water hyacinths grown on solid residue was $89 \%$ of those grown on liquid residues during the nine weeks these cultures were monitored concurrently. This difference was not statistically significant $(P>0.05)$.

Water hyacinths grown on digester residues have compositions similar to those grown on chemically enriched medium in terms of percentage ash, carbon, and nitrogen. Cultures that did not receive nutrient enrichments had reduced levels of ash and nitrogen but enhanced carbon content and carbon: nitrogen ratios (Tabla 4).

An approximate balance of the nitrogen recycled through the culture-digester-culture was made. Over the 39-week experimental period, one digester was loaded with a total of $532 \mathrm{~kg}$ wet weight of water hyacinths. This biomass was $21.3 \mathrm{~kg}$ in ash-free dry weight and contained $577 \mathrm{~g} \mathrm{~N}$. Of this $\mathrm{N}, 48 \%(276 \mathrm{~g} \mathrm{~N})$ was recovered in the 
Table 3. Mean monthly yields ( \pm standard error) of water hyacinths (Eichhornia crassipes) grown in unenriched water, in chemically-enriched medium, and in liquid and solid digester residues).

\begin{tabular}{|c|c|c|c|c|}
\hline \multirow[t]{2}{*}{ Month } & \multicolumn{4}{|c|}{ Mean monthly yield (g ash-free dry weight $/ \mathrm{m}^{2} /$ day) } \\
\hline & Unenriched & Chemical medium & Liquid residue & Solid residue \\
\hline August 1978 & $14.25 \pm 4.40$ & $19.76 \pm 5.90$ & $24.68 \pm 4.27$ & ---- \\
\hline September 1978 & $6.72 \pm 1.30$ & $11.38 \pm 2.68$ & $19.05 \pm 1.70$ & --- \\
\hline October 1978 & $2.24 \pm 0.59$ & $10.10 \pm 2.55$ & $14.74 \pm 1.39$ & $-\cdots$ \\
\hline November 1978 & $1.68 \pm 123$ & $9.66 \pm 1.44$ & $13.77 \pm 1.42$ & --- \\
\hline December 1978 & ---- & $1.54 \pm 0.68$ & $6.81 \pm 1.09$ & $\cdots$ \\
\hline January 1979 & --- & $2.03 \pm 1.36$ & $4.02 \pm 1.58$ & -- \\
\hline February 1979 & ---- & $2.23 \pm 1.15$ & $8.23 \pm 2.27$ & $---\infty$ \\
\hline March 1979 & $\cdots$ & $10.51 \pm 1.75$ & $13.31 \pm 1.60$ & $11.15 \pm 2.19$ \\
\hline Apr11 1979 & --- & $13.29 \pm 1.59$ & $24.48 \pm 1.71$ & $22.45 \pm 2.45$ \\
\hline $\begin{array}{c}\text { Time-we Ighted } \\
\text { mean }\end{array}$ & $5.79 \pm 1.59$ & $8.67 \pm 1.06$ & $14.25 \pm 1.25$ & $18.78 \pm 2.56$ \\
\hline $\mathrm{n}$ & 15 & 39 & 39 & 9 \\
\hline
\end{tabular}


Table 4. Mean (t standard error) ash, organic, carbon, and nltrogen composition and carbon nitrogen ratio of water hyacinths (Eichhornia crassipes) grown in unenriched water, in chemicaliy enriched medium, and in liquid and solid digester residues.

\begin{tabular}{lcccc}
\hline & \multicolumn{4}{c}{$\%$ of dry weight } \\
\cline { 2 - 5 } Unenriched & Chemical medium & Liquid residue & Solid residue \\
\hline Ash & $15.46 \pm 0.66$ & $21.21 \pm 0.29$ & $20.70 \pm 0.23$ & $19.89 \pm 0.43$ \\
Organic & $84.54 \pm 0.66$ & $78.79 \pm 0.29$ & $78.30 \pm 0.23$ & $80.11 \pm 0.43$ \\
Carbon & $39.00 \pm 0.62$ & $36.06 \pm 0.24$ & $37.08 \pm 0.21$ & $37.40 \pm 0.30$ \\
Nitrogen & $1.04 \pm 0.04$ & $3.04 \pm 0.07$ & $2.65 \pm 0.07$ & $2.75 \pm 0.20$ \\
Carbon:Nitrogen & $38.36 \pm 1.55$ & $12.19 \pm 0.35$ & $14.58 \pm 0.44$ & $14.16 \pm 1.03$ \\
$n$ & 15 & 39 & 39 & 9
\end{tabular}


liquid residue and $52 \%(303 \mathrm{~g} \mathrm{~N}$ ) was recovered in the solid residue. In $a 11,5251$ of 1 fquid effluent was removed containing an average of $526 \mathrm{mg} \mathrm{N} / 1$ (a total of $276 \mathrm{~g} \mathrm{~N}$ ), of which about $50 \%$ was in the form of $\mathrm{NH}_{4}-\mathrm{N}$ and the remainder was organic $\mathrm{N}$ of an unknown identity. Addition of this liquid effluent to cultures of water hyacinths produced $4.7 \mathrm{~kg}$ ash-free dry weight which contained $179 \mathrm{~g} \mathrm{~N}$ over a 39-week period, recycling efficiency of $65 \%$. A total of $120.4 \mathrm{~kg}$ of solid residue was removed from the digester. This was equivalent to $4.6 \mathrm{~kg}$ ash-free dry weight and contained $303 \mathrm{~g} \mathrm{~N}$. Recycling $24 \mathrm{~kg}$ wet weight (equivalent to $0.9 \mathrm{~kg}$ ash free dry weight and containing $60 \mathrm{~g} \mathrm{~N}$ ) of this material produced $1.1 \mathrm{~kg}$ ash-free dry weight containing $39 \mathrm{~g} \mathrm{~N}$ over an eight-week period, a recycling efficiency of $64 \%$.

In summary (Fig. 3), for every $100 \mathrm{~g} \mathrm{~N}$ loaded into the digester In the form of chopped water hyacinths, $48 \mathrm{~g} \mathrm{~N}$ were found in the liquid residue, half of which was in the form of $\mathrm{NH}_{4}-\mathrm{N}$. Of this $48 \mathrm{~g} \mathrm{~N}, 31.2 \mathrm{~g} \mathrm{~N}(65 \%)$ was reassimilated by water hyacinths. The solid residue removed from the digester contained $52 \mathrm{~g} \mathrm{~N}$ of the original $100 \mathrm{~g} \mathrm{~N}$. Of this fraction $33.3 \mathrm{~g}(64 \%)$ were reassimilated by water hyacinths. Thus, of the original $100 \mathrm{~g} \mathrm{~N}, 64.5 \mathrm{~g} \mathrm{~N}$ could be successfully recycled from the digesters back to cultures of water hyacinths (an overall recycling of $64.5 \%$ ).

This study has demonstrated that water hyacinths can be easily fermented to produce methane gas and that the digester residues (both liauid and solid) are a rich source of nutrients that can be 
(1)

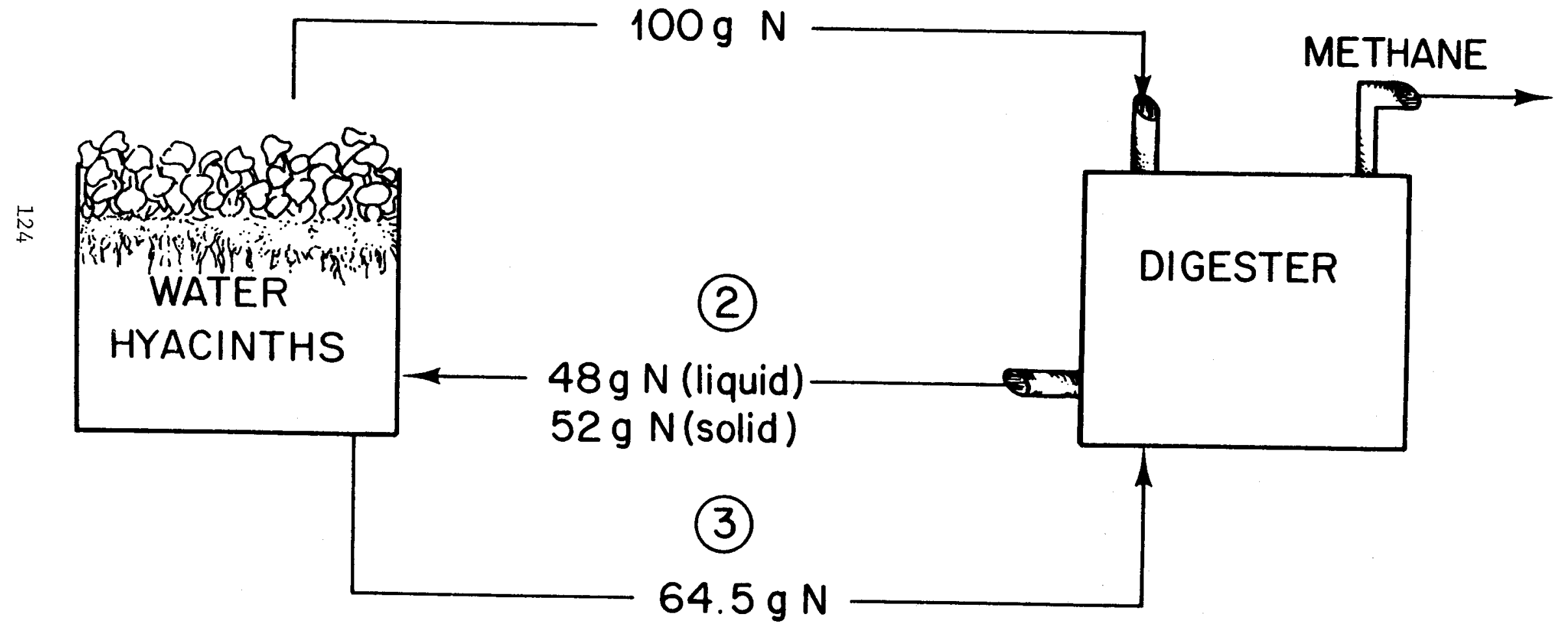
Figure 3. Nitrogen balance in the recycling of digester residues from the anaerobic digestion of water
hyacinths. 
recycled to produce additional biomass of water hyacinths. Both the gas production $(0.4 \mathrm{l} / \mathrm{g}$ volatile solids, at $60 \%$ methane) and the bioconversion efficiency ( $47 \%$ ) compare favorable with those obtained with other substrates (e.g., 4-7), although the loading rate employed in this study was low for a continuous digester. When the loading rate was increased, both $\mathrm{pH}$ and gas production decreased, an observation which suggests that the activity of the acidogenic bacteria inhibited the methanogenic flora at high loading rates.

In as much as these digesters were not mixed in any way, a stratification of the solid phase may have prevented more complete digestion. Increased methane production might be expected to occur if the contents of the digester were mixed; however, the net energy yield might actually decrease whth mixing as has been observed by Jewel1 (7) in the digestion of cow manure. Jewell has also observed similar effects of Increasing the temperature on methane production, 1.e., total methane production increases while net energy yleld decreases. Our work and that of Jewell indicate the potential favorable net energy yields of non-intensive digestion of biomass. The fact that water hyacinths can be successfully digested in a batch mode, with little or no inoculum, and at or near ambient temperature, suggests that this spectes could be readily digested on a large-scale using non-energy-intensive methods and involving low capital costs (e.g., covered plastic-1ined ditches operated in a batch mode without mixing or heating). 
The digester residues are an excellent source of nutrients for additiona 1 growth of water hyacinths. Both the liquid and the solid fractions can supply all the required nitrogen, phosphorus, and trace metals for maximal growth of water hyacinths. This study also indicates that a batch system of growing water hyacinths is as productive as a flow-through one dally requiring large amounts of water (1). The abllity to grow water hyacinths on as little water as possible increases the economic feasibility of any largescale cultivation of this species.

The enhanced yield of batch cultures grown on digester residues relative to those grown on chemically enriched ones is probably the result of better chelation of the trace elements required for growth. This conclusion is supported by the improved growth observed when the follage was sprayed with a trace metal solution or when the trace metals were added in a chelated form (with ethylene diamine-tetracetate).

The productivity of water hyacinths varies seasonally, as observed during this study and elsewhere (1). The efficiency of recycling the digester residues could probably be enhanced by taking this seasonality of growth into consideration. Water hyacinths grow much less during the winter and therefore have much less nutrient requirements. Less digester residue should be added then because relatively less of the nitrogen is absorbed by the plants and more is lost from the system due to such processes as denitrification and volatilization to the atmosphere. 
The nutritional value of the solid residue is as good as that of the liquid residue. It is important to try to recycle the solid fraction as well as the liquid fraction because more than half of the useable nutrients can be found there. Earlier studies with algae $(8,9)$ also found a high percentage of the nutrients in the solid residue, but those studies suggested that these nutrients would not be readily assimilated by the algae until further oxidation of these solids by aerobic bacteria occurred. Presumably this oxidation step occurs readily in the tanks of water hyacinths. The solids act as a complex fertilizer that breaks down slowly releasing required elements for plant growth.

Utilization of these nutrients in the digester residue is a major development in the bioconversion of biomass to fuel. Rather than considering them only as a waste product of digestion and disposing of them (e.g., 10), they may be considered a means of recovering a prectous resource which can be recycled and reused over and over again. The use of these nutrients is probably necessity for any major bioconversion system using plant blomass $(11,12)$.

Because of its high productivity and nutrient removal rates, water hyacinths could be used in advanced sewage treatment. For example, a plant producing $3.8 \times 10^{7} 1$ of secondary sewage per day contalning $25 \mathrm{mg} \mathrm{N} / 1$ could support an annual yield of water hyacinths of about $1.4 \times 10^{4} \mathrm{mg} / \mathrm{y}$ dry weight. If this biomass was then fermented anaerobically, $100 \mathrm{TJ}$ of energy in the form of methane would 
be produced as well as a nutrient-rich fertilizer which would contain about $350 \mathrm{mg}$ of nitrogen. Use of this fertilizer obtained in the digestion process would help to conserve energy as it could be used to replace fertilizer produced in more conventional ways. For example, nitrogen fertilizer requires about 47-59 GJ/mg of $\mathrm{N}$ (13) to manufacture conventiona11y. So the $350 \mathrm{mg}$ of $\mathrm{N}$ contained in the digester residue of the above sewage plant would conserve on average an additional $19 \mathrm{TJ}$ joules of energy. Thus, the energy conserved by recycling just this one element would be significant, amounting to $19 \%$ of the energy produced in the form of methane. 
References

1. DeBusk, T. A., M. D. Hanisak, L. D. Williams and J. H. Ryther. In Press. Primary production of some freshwater macrophytes. Aquatic Botany.

2. American Public Health Association. 1971. Standard methods for the examination of water and wastewater. 13th edition. American Public Health Association, Washington, D.C. 874 pp.

3. Boyd, C. E. 1969. The nutritive value of three species of water weeds. Econ. Bot. 23: 123-127.

4. Savery, C. W. and D. C. Cruzan. 1972. Methane recovery from chicken manure digestion. J. Wat. Pol. Contr. Fed. 44: 2349-2354.

5. Jewe11, W. J. (Ed.) 1975. Energy, Agricu1ture and Waste Management. Ann Arbor Science Publishers, Inc. Ann Arbor, Mich. $540 \mathrm{pp}$.

6. Pfeffer, J. T. 1977. Blological conversion of biomess to methane. U.S. Department of Energy, Washington, D.C. 47 pp.

7. Jewe11, W. J. 1979. Anaerobic fermentation of agricultural residues--potential for improvement and implementation. U.S. Department of Energy, Washington, D.C. 43 pp.

8. Golueke, C. G. and W. J. Oswald. 1959. Biological conversion of light energy to the chemical energy of methane. Appl. Microbiol. 7: 219-227.

9. Uzie1, M., W. J. Oswald and C. G. Golueke. 1975. Solar energy fixation and conversion with algal bacterial systems. Final Reports to National Science Foundation. Sanitary Engineering Research Laboratory, University of California, Berkeley.

10. Jewe11, W. J. and G. R. Morris. 1974. The economic and technical feasibility of methane generation from agricultural wastes. In: P. J. Catania (Ed.) Proc. Symposium on Uses of Agricultural Wastes: Food, Fuel, Fertilizer, University of Regine, Sask., Canada, pp. 132-164.

11. Goldman, J. C. and J. H. Ryther. 1977. Mass production of algae: bioengineering aspects. In: A. Mitsui, S. Miyachi, A. San Pietro and S. Tamura (Eds.), Biological Solar Energy Conversion. Academic Press, New York, Pp. 363-378. 
12. Oswald, W. J. and J. R. Benemann. 1977. A critical analysis of bioconversion with microalgae. In: A. Mitsui, S. Miyachi, A. San Pietro and S. Tamura (Eds.), Biological Solar Energy Conversion, Academic ress, New York, pp. 379-396.

13. Sherf, J. L. 1975. Energy use and economics in the manufacture of fertilizers. In: W. J. Jewel1 (Ed.), Energy, Agriculture and Waste Management. Ann Arbor Science Publishers, Inc., Ann Arbor, Mich. pp. 433-441. 
VIII. Recycling digester residues as a source of nutrients for the growth of Gracilaria tikvahiae.

by

M. Dennis Hanisak and L. D. Williams

Grac1laria tikvahiae was fermented from October, 1978 to October, 1979 in two digesters similar to those previously described for the digestion of the water hyacinth (Eichhornia crassipes) (see Chapter 7). The first attempts to digest Gracilaria were unsuccessful; these included using fermenting dairy manure or water hyacinths as an inoculum or using the Gracilaria alone. Digestion was eventually started by loading the following into the digester: 201 of anaerobic sediments collected in the Indian River in an area of decaying seaweeds and seagrasses, 201 of seawater, and 5-25 $\mathrm{kg}$ wet weight of Gracilaria. Gas production began within 5 days. No pretreatment of any kind was needed to digest Gracilaria.

The digester was loaded at approximately weekly intervals, usually with $5 \mathrm{~kg}$ wet weight (which is equivalent to $0.40 \mathrm{~g}$ volatile solids/1 digester volume.day). The contents of the digester were mixed manually at each loading; this was the only agitation employed.

The digesters were kept at ambient temperature $\left(30^{\circ} \mathrm{C} \pm 5^{\circ} \mathrm{C}\right)$ during most of the year. During the cooler months of the year (NovemberMarch), the digesters were kept partially submerged in a 38001 circular water tank which was kept at approximately $30^{\circ} \mathrm{C}$ by an immersion heater. 
To investigate the sultablifty of the digester residue as a nutrient source for growing Gracilaria, batch cultures, maintained at a density of $2.6 \mathrm{~kg}$ wet weight $/ \mathrm{m}^{2}$, were grown in aerated, 551 chambers like those described by Lapointe and Ryther (1978). These cultures received either various amounts of liquid digester residue, enrlched seawater (see Table 1), or unenriched seawater. The water was changed once a week, at which time the cultures were harvested, weighed, and the incremental growth removed.

Levels of nitrate, nitrite, ammonium, and phosphate were monitored (APHA, 1971) In the tanks prior to and after the additions of digester residues. The nitrogen and carbon contents of plants or solid residue were determined with a Perkin-E1mer Model 240 Elemental Analyzer. The amount of organic matter (i.e., volatile solids) of plants or solid residue was determined after ashing dried samples (dried at $60^{\circ} \mathrm{C}$ for $48 \mathrm{hrs}$ ) for four hours at $550^{\circ} \mathrm{C}$ in a muffle furnace.

To date, Gractlaria has been digested for over a year, with an average gas production of $0.4 \mathrm{l} / \mathrm{g}$ volatile solids, at $60 \%$ methane (Table 2). The heat of combustion of Gracilaria is $4.5 \mathrm{kcal} / \mathrm{g} \mathrm{ash}$ free dry weight (Lapointe and Ryther, 1978) or $19 \mathrm{k} \mathrm{J} / \mathrm{g}$ volatile solids. Since pure methane has an energy content of approximately $37 \mathrm{~kJ} / 1$ the above methane production represents an average bioconversion efficiency of about $47 \%$. 
Table 1. Composition of enrichment medium used for growing Gractlaria tikvahiae.

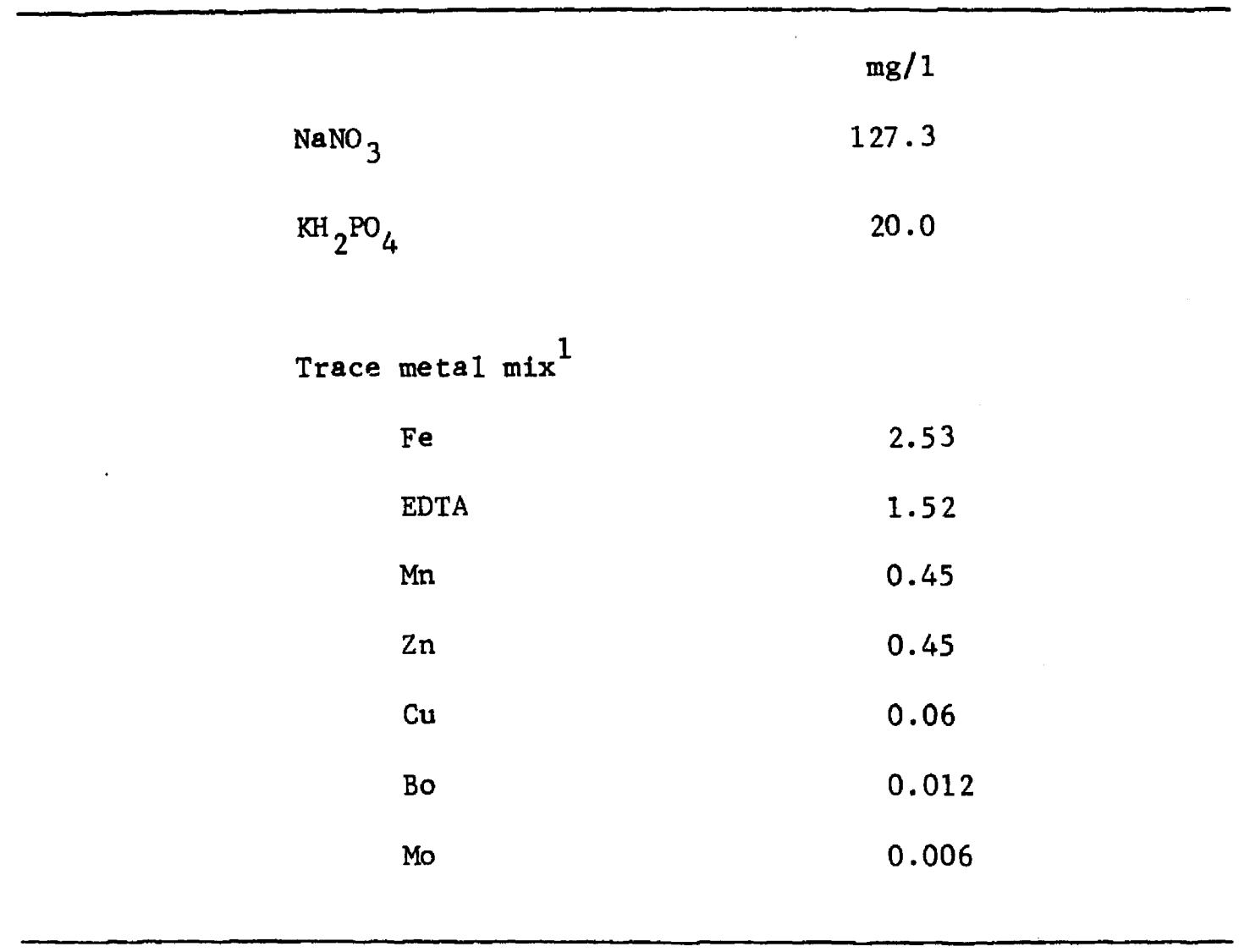

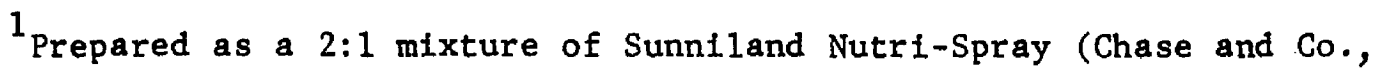
Sanford, FL) and Vigord Liquid Iron (Swift Agricultural Chemicals Corp., Winter Haven, FL). 
Table 2. Characteristics of stable, continuous anaerobic digestion of Gracilaria t1kvahiae.

\begin{tabular}{ll}
\hline Temperature & $30^{\circ} \mathrm{C}+5{ }^{\circ} \mathrm{C}$ \\
Agitation & None \\
Load composition & $\begin{array}{l}\text { Gracilaria at } 11 \% \text { total solids, } \\
\text { of which } 58 \% \text { is volatile solids }\end{array}$ \\
Mean loading rate & $\begin{array}{l}0.43 \mathrm{~g} \text { volatile solids/1 digester/ } \\
\text { day }\end{array}$ \\
Normal pH range & $\begin{array}{l}6.8-7.5 \\
\text { Gas production }\end{array}$ \\
Bloconversion efficiency & $\begin{array}{c}0.41 / \mathrm{g} \text { volatile solids, at } 60 \% \\
\text { methane }\end{array}$ \\
\hline
\end{tabular}


The liquid digester residue was an excellent source of nutrients for the growth of Gracliaria (Table 3). There was no significant differences in growth between cultures that were enriched with a defined chemical medium and those that received liquid digester residue. The unenriched controls grew slowly at the start of the study but ceased growing after their nutrlent reserves were depleted.

The composition of Gracilaria grown on liquid digester residue is simflar to those enriched with culture medium in terms of percentage ash, organic, and carbon (Table 4). Enhanced fitrogen content and, consequently, a reduced $\mathrm{C}: \mathrm{N}$ ratio of the plants grown in digester residue were significantly different than those grown on the defined medium. There were no significant differences in composition resulting from the different concentrations of digester residue used. The unenriched controls had reduced ash and nitrogen levels and elevated $C: N$ ratios relative to the enriched cultures. An approximate balance of the nitrogen recycled through the culture-digester-culture system was made. Over the course of the study, one digester was loaded 55 times with a total load of 312.5 $\mathrm{kg}$ wet weight of Gracilaria. This biomass was equivalent to $20.2 \mathrm{~kg}$ ash-free dry welght and contained $893.1 \mathrm{~g} \mathrm{~N}$. of this $\mathrm{N}, 65 \%(582.5$ was recovered in 3051 of 11quid residue and $29 \%(260.9 \mathrm{~g} \mathrm{~N})$ was recovered in the $116 \mathrm{~kg}$ of solid residue. The liquid residue contalned an average $1.91 \mathrm{~g} \mathrm{~N} / 1$, of which about $66 \%$ was in the form of $\mathrm{NH}_{4}-\mathrm{N}$ and the remainder was organic nitrogen of an unknown identity. 
Table 3. Monthly mean yields ( \pm standard error) of Gracilaria tikvabiae grown in unenriched seawater, in chemically-enriched medium, and in liquid digester residue.

\begin{tabular}{|c|c|c|c|c|}
\hline \multirow{3}{*}{$\begin{array}{l}\text { Month } \\
\text { (1979) }\end{array}$} & \multicolumn{4}{|c|}{ Mean yield (g ash-free dry weight $/ \mathrm{m}^{2} /$ day) } \\
\hline & \multirow[t]{2}{*}{ Unenriched } & \multirow[t]{2}{*}{ Chemically-enriched } & \multicolumn{2}{|c|}{ Linuid digester residue ${ }^{1}$} \\
\hline & & & A & B \\
\hline Tanuary & $2.88 \pm 0.69$ & $2.72 \pm 0.69$ & $4.37 \pm 0.94$ & $3.79 \pm 0.92$ \\
\hline February & $2.92+0.48$ & $3.00 \pm 0.61$ & $4.12 \pm 0.54$ & $4.36+0.68$ \\
\hline March & $2.33+0.78$ & $2.40+0.64$ & $3.72 \pm 1.10$ & $4.78+1.26$ \\
\hline$\Lambda$ pr 11 & $1.10+0.51$ & $5.55 \pm 0.87$ & $6.64 \pm 1.22$ & $8.05+1.53$ \\
\hline May & $\cdots$ & $8.39 \pm 0.92$ & $8.22 \pm 1.48$ & $8.19 \pm 1.05$ \\
\hline June & -- & $9.09 \pm 0.82$ & $8.71 \pm 0.52$ & $5.62 \pm 1.22$ \\
\hline July & -- & $12.03 \pm 2.42$ & $15.11 \pm 1.55$ & $11.80 \pm 1.86$ \\
\hline August & --- & $14.03 \pm 1.93$ & $16.86 \pm 1.86$ & $17.39 \pm 1.99$ \\
\hline September & -- & $5.37 \pm 1.74$ & $10.06 \pm 2.14$ & $8.65 \pm 1.48$ \\
\hline October & -- & $4.73 \pm 2.61$ & $8.26 \pm 0.80$ & $9.08 \pm 1.11$ \\
\hline Grand Mean & $2.27+0.32$ & $7.11 \pm 0.62$ & $8.62+0.64$ & $8.65 \div 0.63$ \\
\hline $\mathrm{n}$ & 30 & 74 & 74 & 74 \\
\hline
\end{tabular}

${ }_{A} A$ and $B$ received 1.0 and 0.51 respectively of liquid digester residue. 
Table 4. Mean ( \pm standard error) ash, organic, carbon, and nitrogen composition and carbon:nitrogen ratio of Gracilaria tikwahiae grown in unenriched seawater, in chemically enriched medium, and in liquid digester residue.

\begin{tabular}{|c|c|c|c|c|}
\hline \multirow{3}{*}{$\begin{array}{c}\text { Month } \\
\text { (1979) }\end{array}$} & \multicolumn{4}{|c|}{$\%$ of dry weight } \\
\hline & \multirow[t]{2}{*}{ Unenriched } & \multirow[t]{2}{*}{ Chemically enriched } & \multicolumn{2}{|c|}{ Liquid digester residue ${ }^{1}$} \\
\hline & & & A & B \\
\hline Ash & $33.92 \pm 0.62$ & $36.25 \pm 0.55$ & $37.95 \pm 0.68$ & $36.69 \pm 0.52$ \\
\hline Organic & $66.08 \pm 0.62$ & $63.75 \pm 0.55$ & $62.05 \pm 0.68$ & $63.31 \pm 0.52$ \\
\hline Carbon & $28.58 \pm 0.35$ & $26.91 \pm 0.31$ & $27.21 \pm 0.28$ & $27.33 \pm 0.27$ \\
\hline Nitrogen & $1.43 \pm 0.08$ & $2.54 \pm 0.05$ & $3.46 \pm 0.11$ & $3.19 \pm 0.09$ \\
\hline Carbon:nitrogen & $21.93 \pm 1.37$ & $10.82 \pm 0.17$ & $8.40 \pm 0.26$ & $8.96 \pm 0.22$ \\
\hline $\mathfrak{n}$ & 30 & 74 & 74 & 74 \\
\hline
\end{tabular}

${ }^{1} A$ and $B$ received 1.0 and 0.51 respectively of 1 iquid digester residue. 
Addition of this liquid effluent over a 292 day period to cultures of Gracilaria at the rate of 1 11ter/week produced $578.9 \mathrm{~g}$ ash-free dry weight which contained $32.3 \mathrm{~g} \mathrm{~N}$; when added at the rate of 0.511 ter/week, $580.9 \mathrm{~g}$ ash-free dry welght was produced containing $29.3 \mathrm{~g} \mathrm{~N}$. This corresponds to a recycling efficiency of 40.2 and $73.0 \%$ respectively. Since there was no difference in biomass ylelds due to the different levels of residue addition, both cultures had sufficient nutrients for maximal growth. The higher enrichment provided excess nutrients that were not assimilated by Gracilaria, thus causing a reduction in recycling efficiency. At the present time, then, a recycling efficiency of $73.0 \%$ is the best estimate of the reassimilation of nitrogen by Gracilaria from the residue.

Using these estimates, the culture-digester-culture system may be briefly summarized (FIg. 1). For every $100 \mathrm{~g} \mathrm{~N}$ added to the digester in the form of Gracilaria, $29 \mathrm{~g} \mathrm{~N}$ were recovered in the solid residue and $65 \mathrm{~g} \mathrm{~N}$ were recovered in the liquid residue. of this $65 \mathrm{~g} \mathrm{~N}, 48 \mathrm{~g}(73 \%)$ was reassimilated by Gractlaria. Thus, of the original $100 \mathrm{~g} \mathrm{~N}, 48 \mathrm{~g} \mathrm{~N}$ would be completely recycled from the digester back to cultures, an overall recycling efficiency of $48 \%$.

This study demonstrated that Gracilaria can be readily fermented to produce methane and that the liquid digester residue can be recycled to produce additional biomass of Gracilaria. The gas production and the bioconversion was the same as that reported for the freshwater macrophyte Eichhornia crassipes digested under similar 
(1)

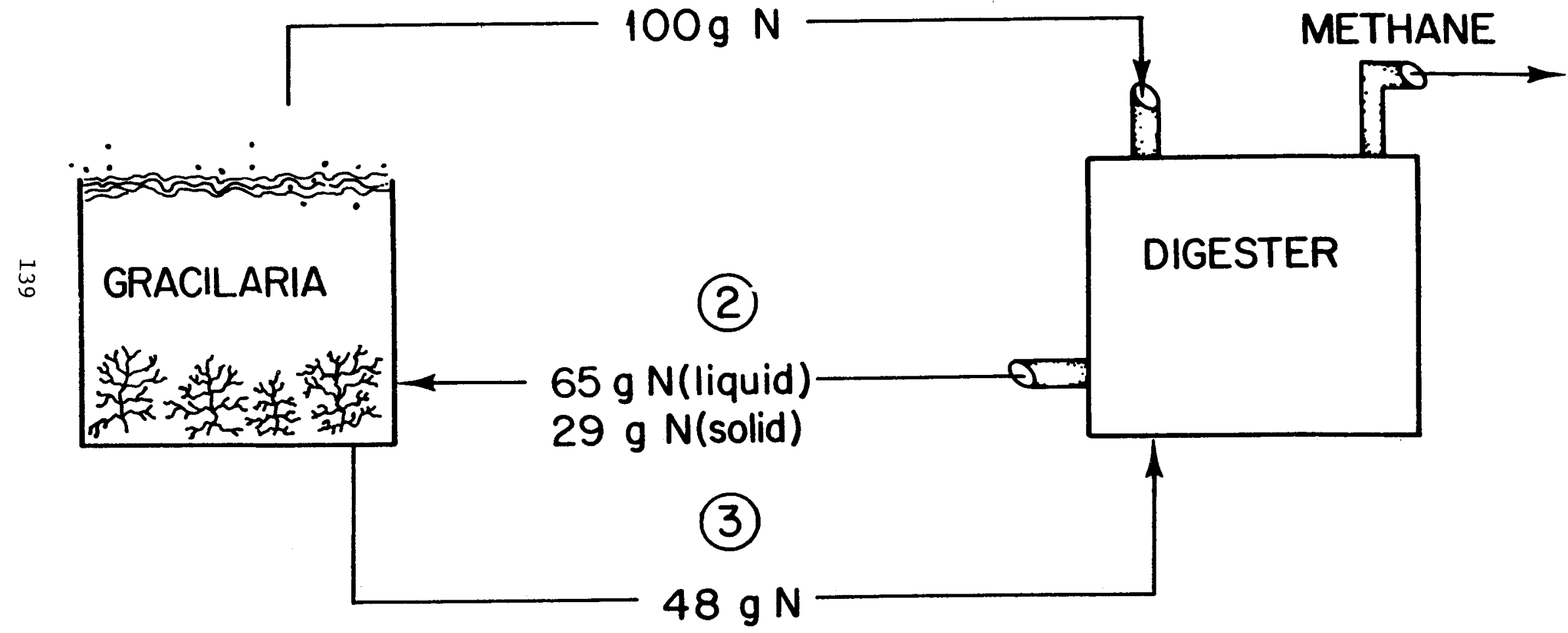

F1gure 1. Nitrogen balance in the recycling of digester residue from the anaerobic digestion of Gracilaria. 
conditions (see Chapter 7). This suggest that estimates of digestibility made on the basis of these species are probably fairly representative for aquatic plant blomass under these conditions. There were some differences between the two species in the recycling efficiency of nitrogen. The overall recycling of nitrogen was greater for Elchhornia ( 65 vs. $48 \%$ ) because of the ability to recycle solid, as well as liquid, residue. Observation of solids from digesters of Gracilaria suggested they were not as readily blodegradable, but their potential of recycling needs to be explored. Although the overall efficiency of recycling was less for Gracilaria, Its liquid digester residue did have a higher percentage of nitrogen In the form of $\mathrm{NH}_{4}-\mathrm{N}$ ( 66 vs. $50 \%$ ) and was more readfly reassimilated (73\% v8. $65 \%$ ) than that of Elchhornia.

Despite these differences, nutrients were conserved during the digestion of both species and the nutrients in the liquid residue were readily reassimilated by cultures of both species, with yields as high or higher than cultures receiving chemical enrichment. This is important to the development of "energy farms" employing these species because one of the major costs involved (in terms of both economics and energy) is that of fertilizer. Recycling of nutrients is probably a necessity for such an "energy farm" (Goldman and Ryther, 1977; Oswald and Benemann, 1977).

It is possible that digester effluent might be the only external of nutrient enrichment needed to grow Gracilaria in a flowing seawater system, even assuming a recycling efficiency of only $48 \%$ (a value 
which can probably be improved to $60-65 \%$ with further experimentation), if the seawater source itself is moderately eutrophic. For example, Gracilaria, growing in the $929 \mathrm{~m}^{2}$ pond being stocked at the Harbor Branch Foundation, filled to a depth of $1 \mathrm{~m}$ and receiving 2 exchanges of unenriched seawater per day (which has an average nftrogen concentration of $8 \mu$ moles/1), would receive enough nitrogen to support 6.6 $g$ ash-free dry weight $/ \mathrm{m}^{2} /$ day (assuming an internal nitrogen concentration of $2.0 \%$ ). If Gracilaria grew at an average of $12 \mathrm{~g}$ ash-free dry weight $/ \mathrm{m}^{2} /$ day and was fermented to methane, the resulting residue could support an additional $5.8 \mathrm{~g}$ ash-free dry weight $/ \mathrm{m}^{2} / \mathrm{day}$. Thus, the nutrients contained in only the unenriched seawater and the 1iquid digester residue could provide enough nutrients to support the assumed $12 \mathrm{~g}$ ash-free dry weight $/ \mathrm{m}^{2} /$ day without the need to use conventional fertilizers. The "energy farm" would then be operating like a natural ecosystem where energy flows through the system while nutrients cycle within the system.

Further improvements in such an "energy farm" might be achieved by recycling the solid residue as a source of nutrients or by combining the gas production and nutrient recycling with agar production from Gracilaria. Agar is a commercially important and economically valuable natural product which might be extracted either before or after Gracllaria is loaded into the digesters. Such a combined system could lead to a major aquaculture crop being cultivated in a closed nutrient system, with energy requirements met, at least in part, by the methane generated within the system. 
References

American Public Health Association. 1971. Standard methods for the examination of water and wastewater. 13th edition. American Public Health Association, Washington, D.C. 874 pp.

Goldman, J. C. and J. H. Ryther. 1977. Mass production of algae: bioengineering aspects. In: A. Mitsui, S. Miyachi, A. San Pietro and S. Tamura (Eds.), Biological Solar Energy Conversion. Academic Press, New York, pp. 363-378.

Hanisak, M. D., L. D. Williams and J. H. Ryther. 1979. Recycling the nutrients in residues from methane digesters of aquatic macrophytes for new blomass production. Resource Recovery and Conservation. (In press)

Lapointe, B. E. and J. H. Ryther. 1978. Some aspects of the growth and yield of Gracilaria tikvahiae in culture. Aquaculture 15: 185-193.

0swald, W. J. and J. R. Benemann. 1977. A critical analysis of bioconversion with microalgae. In: A. Mitsui, S. Miyachi, A. San Pletro and S. Tamura (Eds.), Blological Solar Energy Conversion. Academic Press, New York. pp. 379-396.

Ryther, J. H., L. D. Williams, M. D. Hanisak, R. W. Stenberg and T. A. DeBusk. 1978. Biomass production by some marine and freshwater plants. In: W. W. Wshuster (Ed.), Proc. Second Fuels from Blomass Symposium, Rensselaer Polytechnical Institute, Troy, N.Y. 2: 978-989.

Ryther, J. H., L. D. Williams, M. D. Hanisak, R. W. Stenberg and T. A. DeBusk. 1979. Biomass production by marine and freshwater plants. Third Annual Biomass Energy Systems Conference, June 5-7, Denver, Colorado. 


\begin{tabular}{|c|c|c|}
\hline $\begin{array}{l}\text { Document Control } \\
\text { Page }\end{array}$ & \begin{tabular}{|l|l|} 
1. SERI Report No. & 2. NTIS Accession No. \\
SERI/TR-98133-1a &
\end{tabular} & 3. Recipient's Accession No. \\
\hline \multirow{2}{*}{\multicolumn{2}{|c|}{$\begin{array}{l}\text { 4. Title and Subtițle } \\
\text { Cultivation of Macroscopic Marine Algae and Fresh } \\
\text { Water Aquatic Weeds }\end{array}$}} & $\begin{array}{l}\text { 5. Publication Date } \\
\text { February } 1982\end{array}$ \\
\hline & & 6. \\
\hline \multicolumn{2}{|l|}{$\begin{array}{l}\text { 7. Author(s) } \\
\text { John H. Ryther }\end{array}$} & 8. Performing Organization Rept. No. \\
\hline \multirow{2}{*}{\multicolumn{2}{|c|}{$\begin{array}{l}\text { 9. Performing Organization Name and Address } \\
\text { Woods Hole Oceanographic Institution } \\
\text { Woods Hole, Massachusetts } 02543\end{array}$}} & 10. Project/Task/Work Unit No. \\
\hline & & $\begin{array}{l}\text { 11. Contract (C) or Grant (G) No. } \\
\text { (C) } \\
\text { (G) }\end{array}$ \\
\hline \multirow{2}{*}{\multicolumn{2}{|c|}{$\begin{array}{l}\text { 12. Sponsoring Organization Name and Address } \\
\text { Solar Energy Research Institute } \\
1617 \text { Cole Boulevard } \\
\text { Golden, Colorado } 80401\end{array}$}} & $\begin{array}{l}\text { 13. Type of Report \& Period Covered } \\
\text { Technical Report }\end{array}$ \\
\hline & & 14. \\
\hline
\end{tabular}

15. Suppiementary Notes

16. Abstract (Limit: 200 words) The "ORCA" clone of the red seaweed Gracilaria tikvahiae has been in culture continuously for over two years. Yield for the past year has averaged $12 \mathrm{~g}$ ash-free dry wt/m² .day (17.5 t/a.yr) in suspended 2600-1 aluminum tank cultures with four exchanges of enriched seawater per day and continuous aeration. Yields fron nonintensive pond-bottom culture, similar to commercial Gracilaria culture methods in Taiwan, averaged $3 \mathrm{~g}$ afdw/m². day in preliminary experiments. Rope and spray cultures were not successful. Yields of water hyacinths from March 1978 to March 1979 averaged $25 \mathrm{~g} \mathrm{afdw} / \mathrm{m}^{2}$, day ( $\left.37 \mathrm{t} / \mathrm{a} . \mathrm{yr}\right)$. Season, nutrient availability (form and quantity) and stand density were found to affect the relative proportions of structural and nonstructural tissue in water hyacinths and thereby significantly affect digestibility of and methane production by the plants. Pennywort (Hydrocotyle) grew poorly in winter and its annual yield averaged only one-third that of water hyacinth. Water lettuce (Pistia) appears more comparable to hyacinths in preliminary studies and its yields will be monitored throughout a complete year. Stable, continuous anaerobic digestion of both water hyacinths and Gracilaria has been maintained with an average gas production from both species of $0 . \overline{4} \mathrm{1/g}$ volatile solids at $60 \%$ methane.

17. Document Analysis

a. Descriptors Aquatic Organisms ; Cultivation ; Gracilaria ; Nitrogen ; Nutrients ; Plants; Productivity; Residues ; Seaweeds; Water Hyacinths

b. Identifiers/Open-Ended Terms

c. UC Categories

18. Availability Statement

National Technical Information Service

U.S. Department of Commerce

5285 Port Royal Road

Springfield, Virginia 22161

19. No. of Pages

152

20. Price 